University of Louisville

ThinkIR: The University of Louisville's Institutional Repository

Electronic Theses and Dissertations

8-2015

\title{
An investigation of the centrality of competing institutional logics for social enterprises.
}

Tae Jun Bae

University of Louisville

Follow this and additional works at: https://ir.library.louisville.edu/etd

Part of the Entrepreneurial and Small Business Operations Commons

\section{Recommended Citation}

Bae, Tae Jun, "An investigation of the centrality of competing institutional logics for social enterprises." (2015). Electronic Theses and Dissertations. Paper 2239.

https://doi.org/10.18297/etd/2239

This Doctoral Dissertation is brought to you for free and open access by ThinkIR: The University of Louisville's Institutional Repository. It has been accepted for inclusion in Electronic Theses and Dissertations by an authorized administrator of ThinkIR: The University of Louisville's Institutional Repository. This title appears here courtesy of the author, who has retained all other copyrights. For more information, please contact thinkir@louisville.edu. 


\title{
AN INVESTIGATION OF THE CENTRALITY OF COMPETING INSTITUTIONAL LOGICS FOR SOCIAL ENTERPRISES
}

\author{
By \\ Tae Jun Bae \\ B.S., Hanyang University, 2004 \\ M.S., Hanyang University, 2006

\begin{abstract}
A Dissertation
Submitted to the Faculty of the College of Business of the University of Louisville in Partial Fulfillment of the Requirements for the Degree of
\end{abstract} \\ Doctor of Philosophy in Entrepreneurship \\ Department of Entrepreneurship \\ University of Louisville \\ Louisville, Kentucky
}

August 2015 
Copyright 2015 by Tae Jun Bae

All rights reserved 



\section{AN INVESTIGATION OF THE CENTRALITY OF COMPETING INSTITUTIONAL LOGICS FOR SOCIAL ENTERPRISES}

\section{By}

Tae Jun Bae

B.S., Hanyang University, 2004

M.S., Hanyang University, 2006

\section{A Dissertation Approved on}

June 1, 2015

by the following Dissertation Committee:

Dr. James O. Fiet: Dissertation Director

Dr. Kristen Lucas

Dr. Andrew Manikas

Dr. Dean Shepherd 


\section{DEDICATION}

This dissertation is dedicated to my parents

Mr. Young Ho Bae and Mrs. Sun Nam Kim

who have given me invaluable educational opportunities. 


\section{ACKNOWLEDGEMENTS}

I am grateful to Korean social enterprises that agreed to participate in this research. I would also like to express a sincere gratitude to social entrepreneurs who volunteered to share with me their business stories. During the data collection, I also had assistance from In-Kyung Lee, the director of Korean Central Council of Social Enterprise, Jae-Gu Kim, President of the Korea Social Enterprise Promotion Agency, and Jung-Wha Han, head of the Small and Medium Business Administration in South Korea. I am grateful to them for their help.

My work would not have been possible without inspiration and advice of my committee. I would like to first thank my dissertation chair Dr. James O. Fiet, for his guidance and patience. He gave me an opportunity to pursue Ph.D. degree. He has been so much more than a dissertation chair for me. I can't thank him enough for his support. I am fortunate to have had Dr. Kristen Lucas, Dr. Andrew Manikas, and Dr. Dean Shepherd serve on my committee. They constantly coached me on the dissertation. I don't know what I would have done without their intelligent comments, insightful reviews, and cheerful encouragement.

My appreciation also goes to internal and external faculty members who taught me at University of Louisville. They not only expanded my perspective, but also strengthened the knowledge and ability to conduct research. I would like to extend my thanks to my friends in 2010 cohort: Shaunn Mattingly,Trayan Kushev, Jason D’Mello, Shanshan Qian, and Dalong Ma. We have been through a lot together during Ph.D 
program. I was happy to work and make friendship with them. I also want to thank former students who graduated earlier: John Mueller, Christopher Crawford, and Krishna Paudel. They did not hesitate to give me valuable advice. I should not also forget to thank Tammy H. Green for her warm-heart assistance. I wish the best for all of them. I also owe my gratitude to people at Management \& Entrepreneurship department of Hofstra University. They hired me and patiently were waiting for me to finish my degree.

Personally, this dissertation is possible because of the endless love and support of my mother, Sun Nam Kim and my father, Young Ho Bae. They have always treated me like a winner. They have inspired me to be as ambitious as I wanted. I am eternally grateful to them. I also owe a debt of gratitude to my grandmother, Hong Kum Park, although she is no longer with me. She would have been happy to see me finish the degree. I want to express my warm thanks to my younger sister and younger brother, Yun Jin and Tae Hun for being my side whenever I needed. I also want to thank my lovely nephew and niece, Jun Young and Hyun Kyoung, who motivated me to shape this dissertation into a better quality. I imagined that they will read it someday when they are grown up.

The journey of the dissertation was also special for me because I was able to meet and marry my loving wife, Ha Young Shin while I was in South Korea for collecting data. I am thankful to my wife for her love, support, and sacrifices. A special word of thanks goes to my parents-in-law, Bok Su Kwak and Baek Kyun Shin, who believed in me and gave me such a great gift - their daughter. Having her in my life completes me. 


\begin{abstract}
AN INVESTIGATION OF THE CENTRALITY OF COMPETING INSTITUTIONAL LOGICS FOR SOCIAL ENTERPRISES
\end{abstract}

Tae Jun Bae

June 1, 2015

Social enterprises have recently been recognized as organizations located in the field where two competing institutional logics co-exist preeminently. My dissertation attempts to examine the conditions under which the centrality of competing institutional logics, referring to the degree to which two competing institutional logics are both important to organizational functioning, is higher or lower in social enterprises. Using hand-collected data from the survey of 190 social enterprises in South Korea, this dissertation not only presents a validated and reliable measure for the centrality of competing logics, but also identifies the factors associated with variation in a social enterprise's centrality of competing logics.

Building on the perspective of heterogeneity in intra-stakeholder group, the Study 1 reveals that the heterogeneity within stakeholders can play a role in shaping the degree of centrality of competing logics. Specifically, ethical investors within investor stakeholders and cross-workers within employee stakeholder may enhance the centrality of competing logics.

Drawing on imprinting perspective, Study 2 shows that there is the curvilinear effect of social entrepreneurs' non-profit experience on the centrality of competing logics. 
Social entrepreneurs' non-profit experience has a positive influence on the centrality of competing logics until reaching a certain point, beyond which that point is likely to be negative. Moreover, the effect of social entrepreneurs' non-profit experience on the centrality of competing logics is less profound in the social enterprises with a highly ambivalent founder.

This dissertation contributes to connect distinct research areas together, which are: (1) social entrepreneurship, (2) institutional logics, (3) stakeholder theory, and (4) imprinting perspective. 


\section{TABLE OF CONTENTS}

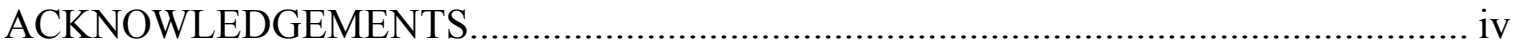

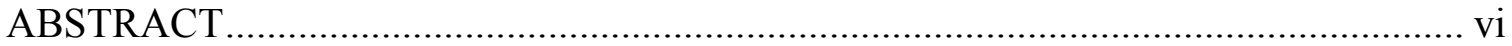

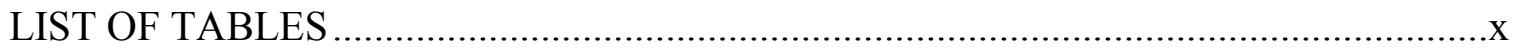

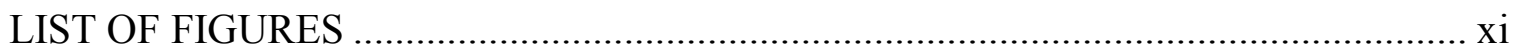

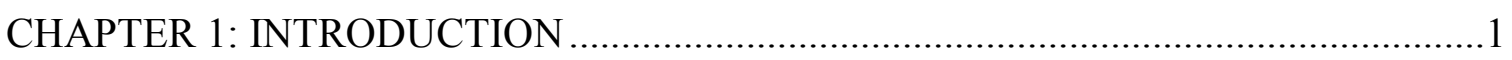

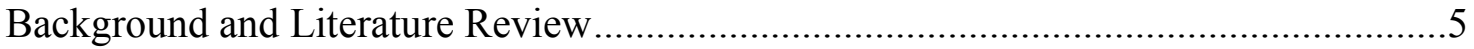

Social entrepreneurship as a field with permanent competing institutional logics. ....5

A Social enterprise's centrality of competing institutional logics...............................8

Scale development for a social enterprise's the centrality of competing logics. .........9

Stakeholders on the centrality of competing institutional logics.................................12

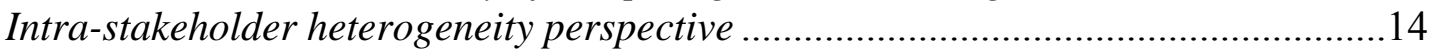

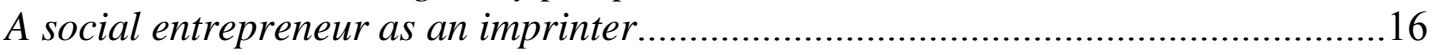

Social entrepreneurs and the centrality of institutional competing logics.................19

Research Questions and Research Objectives........................................................21

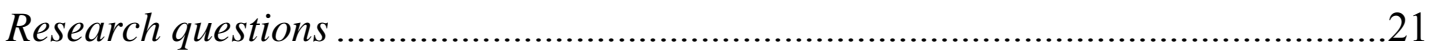

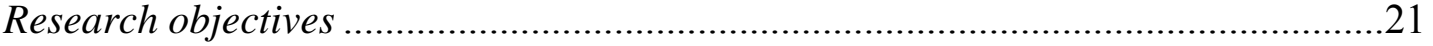

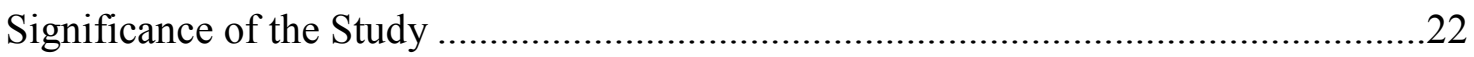

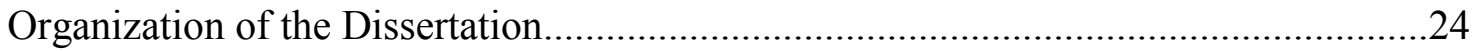

CHAPTER 2: THEORY AND HYPOTHESIS- STUDY ONE ….............................26

Intra-stakeholder Heterogeneity and the Centrality of Competing Logics ...................26

A Resource Dependence Perspective .................................................................26

Ethical Investor within Investor Stakeholder ................................................. 30

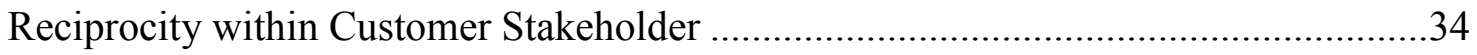

Cross-Sector Workers within Employee Stakeholder ...........................................37

CHAPTER 3: THEORY AND HYPOTHESIS - STUDY TWO ….............................40 
A Social Entrepreneur and the Centrality of Competing Institutional Logics 40

Founder's Prior Work Experience on New Organization....

The Curvilinear Relationship Between a Social Entrepreneur's Non-Profit Experience and the Centrality of Competing Institutional logics .42

The Moderating Role of a Social Entrepreneur's Attributes......................................49

Social Entrepreneur's Ambivalent Interpretation ......................................................49

A Social Entrepreneur's Career Variety ...............................................................52

CHAPTER 4: RESEARCH DESIGN AND METHODS .............................................56

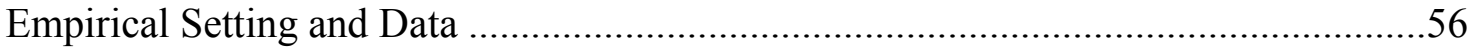

Study One: Measures, Validation, and Statistical Procedures ...................................61

Study Two: Measures, Validation, and Statistical Procedures...................................72

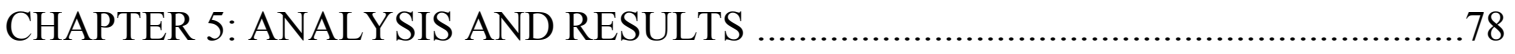

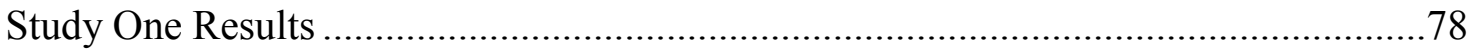

Supplemental Analysis for Study One ......................................................... 83

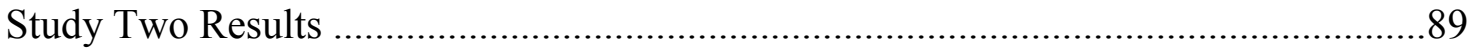

Supplemental Analysis for Study Two...........................................................97



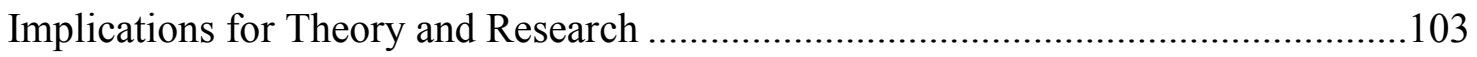

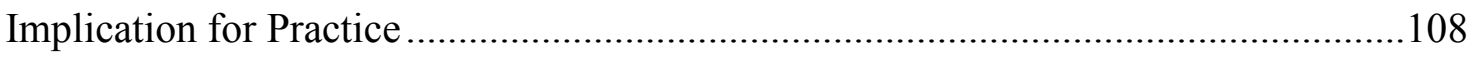

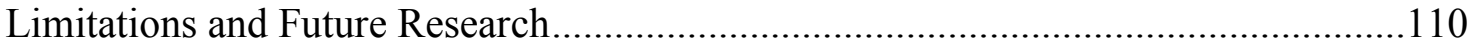

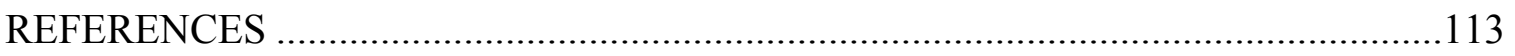

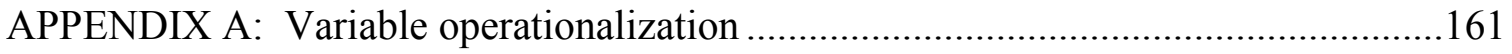

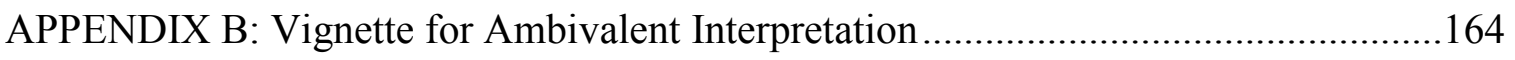

APPENDIX C: Characteristics of Interviewed Social Enterprises ...............................165

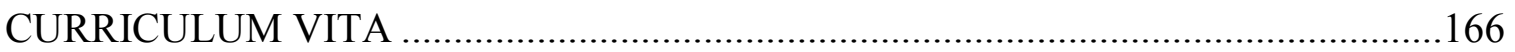




\section{LIST OF TABLES}

TABLE

PAGE

Table 1. Test of Non-Response Bias: Comparison with Non-Respondents .................... 59

Table 2. Test of Non-Response Bias: Early vs. Late 60

Table 3. Validity Assessment for Constructs of Top management's attention to competing issues 63

Table 4. Validity Assessment for Constructs of Ambivalent Interpretation.................... 73

Table 5. Social Entrepreneur's Career Variety: Exploratory Factor Analysis................. 75

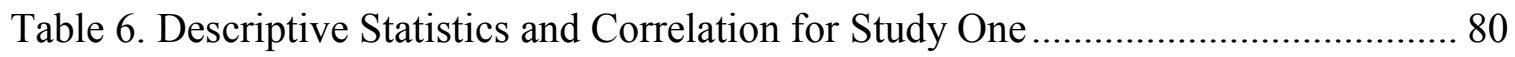

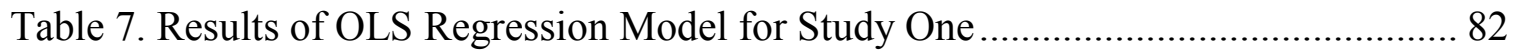

Table 8. Supplementary Analysis Study One: Adding prior centrality of competing logics

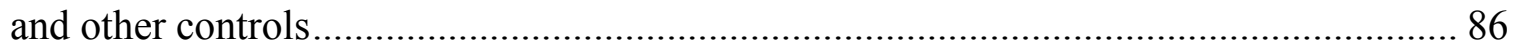

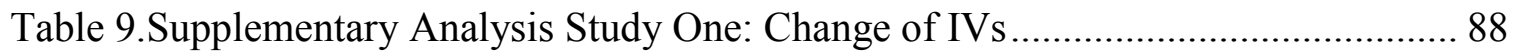

Table 10. Descriptive Statistics and Correlation for Study Two ................................... 90

Table 11. Results of OLS Hierarchical Regression Model for Study Two ..................... 92

Table 12. Results of OLS Hierarchical Regression Model for Study Two ..................... 93

Table 13. Supplementary Analysis for Study Two: Adding prior centrality ................... 98

Table 14.Supplementary Analysis for Study Two: Change of IV to For-profit Exp....... 99 


\section{LIST OF FIGURES}

$\begin{array}{ll}\text { FIGURE PAGE } & \text { PAR }\end{array}$

Figure 1. Conceptual Model for Hypotheses Testing .............................................. 22

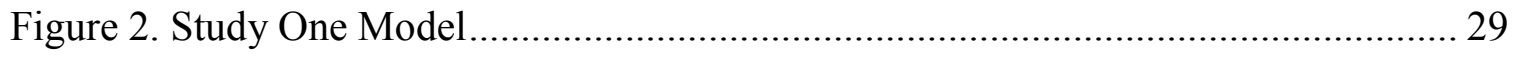

Figure 3. Study Two Model ..................................................................................... 42

Figure 4. Impact of founder's non-profit experience on the centrality of competing logics

Figure 5. Impact of founder's non-profit experience on the centrality of competing logics

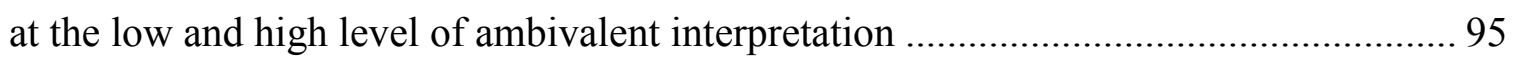




\section{CHAPTER 1: INTRODUCTION}

Social entrepreneurship refers to leveraging economic activities to pursue social objectives (Dees, Emerson, \& Econmy, 2004; Guclu, Anderson \& Deeds, 2002; Fowler, 2000; Mair \& Marti, 2006; Van de Ven, Sapienza, \& Villanueva, 2007; Zahra, Gedajlovic, Neubaum, \& Shulman, 2009). In doing so, social entrepreneurial organizations attempt to embrace potentially conflicting goals (Austin, Stevenson, \& Wei-Skillern, 2006; Mair \& Marti, 2006; Miller, Grimes, McMullen, \& Vogus 2012; Pache \& Santos, 2013). Institutional theorists have described these dual imperatives as facing competing institutional logics, which are defined as conflicting macro-level belief systems and rules that guide organizational decision-making (Pache \& Santos, 2013; Greenwood et al., 2011).

These logics are [1] a social welfare logic, which is a taken-for-granted norm that leads an organization to improve social conditions and care for beneficiaries, such as a neglected class of people, and [2] a commercial logic, which is a value that guides an organization to pursue economic profit and maximize revenue (Pache \& Chrowdhury, 2012; Pache \& Santos, 2013). These two logics sometimes require trade-offs with each other and may be actually quite incompatible (Smith, Gonin, \& Besharov, 2013). At other times, social enterprises are hybrids, which incorporate both competing institutional logics under a single organizational roof (Defourny \& Nyssens, 2006; Doherty, Haugh, \& Lyon, 2014; Jay, 2013). 
Institutional theorists have assumed that the incorporation of both competing logics within a single organization ideally would provide benefits. Accordingly, if social enterprises as hybrid organizations, could incorporate competing institutional logics in a sustainable way; they would be more likely to [1] receive social and material support from those backing each of them (Kraatz \& Block, 2008; Pache \& Santos, 2013), [2] gain legitimacy from external referents, such as resource holders attached to distinct logics (Greenwood et al., 2011), [3] create novel practices and tacit knowledge (Murray, 2010; Stark, 2009), and [4] generate reflexivity, which is the capacity to make self-referential actions (Seo \& Creed, 2002). Other scholars, however, have cast doubt on the presumed benefits of accommodating both competing institutional logics. Integrating long-term competing institutional logics in a single organizational form entails contradictions, and possible negative outcomes, such as [1] a "sense of dissonance" (Stark, 2009), [2] "conflicting demands" (Glynn, 2000), and [3] "internal confusion" (Ashforth et al., 2009). Building on concerns about conflict, scholars have argued that a social enterprise's dual commitment to both competing institutional logics could also create internal tensions, such as [1] measurement problems, [2] identity issues, [3] structuring concerns, and [4] conflicts between short- and long-term goals (Smith \& Lewis, 2011). Consequently, a social enterprise could be incentivized to evade these problems by only supporting either a social-welfare logic or a commercial logic (Smith, Besharov, Wesseles, \& Chertok, 2012).

The inconsistent and at times unpredictable consequences of incorporating competing institutional logics helped scholars to recognize centrality as a new dimension of hybrid organizations (Besharov \& Smith, 2014). The Centrality of institutional 
competing logics refers to the degree to which two competing institutional logics are both important to organizational functioning. If a social enterprise commits to a social mission while pursuing effective operations to generate an economic surplus (Mair, Battilana, \& Cardenas, 2012), the centrality would be high. On the other hand, if a social enterprise loses sight of its social mission, due to placing too much emphasis on financial gain, or if a social enterprise were to focus exclusively on its social mission without considering commercial activities, the centrality would be low.

Understanding the centrality of competing institutional logics is particularly important for social entrepreneurship. First, it could advance our understanding of organizational variety within the social entrepreneurship context. Social entrepreneurship has been viewed as a normative field, which was concerned with the notion that a social welfare logic and a commercial logic should be relatively equally emphasized in order for a social venture to prosper with each of these missions (Austin et al., 2006). However, there are growing bodies of observations that reveal social enterprises attend to social welfare and commercial logic in a hierarchy of prominence inside organizations (Pache \& Santos, 2010; 2013). It illustrates that the relative importance of social welfare logic and commercial logic could vary according to individual social enterprises' priorities. In other words, unlikely to conventional normative perspective, social enterprises have exhibited varying degree of the centrality of competing institutional logics.

Second, investigation of the centrality of competing institutional logics could help uncover the condition under which some social enterprises pay much more attention to either a commercial logic or a social welfare logic, while other social enterprises try not to prioritize one over another logic. To date, social entrepreneurship scholars have 
emphasized on the achievement of high level of the centrality of competing logics (Mair, Battilana, \& Cardenas, 2012). It has been believed that prioritization of either a commercial logic or a social welfare logic, which is the low level of centrality of competing logics, may threaten the legitimacy of social enterprises. Consequently, the researcher has paid scant attention to the phenomenon of varying degrees of the centrality of competing institutional logics within social entrepreneurship field. Although the prioritization of either a commercial logic or a social welfare logic could be regarded as the variation in the centrality of competing logics, relatively few studies have been devoted to detailed examination of the sources of variation in the centrality of competing logics in social enterprises.

Despite its potential contributions to social entrepreneurship, research on centrality is still at an early stage. It is noteworthy that we have little known research to develop and validate a measurement instrument for a social enterprise's centrality of competing logics. The absence of an existing reliable measure of a social enterprise's centrality of competing logics have constrained social entrepreneurship studies from understanding the centrality within the context of social enterprises. Hence, by placing the centrality of competing institutional logics by social enterprises in the foreground, my dissertation attempts to operationalize the measure for a social enterprise's centrality of competing logics. It not only propose the relevant measure of the centrality of competing logics, but it also validate and test the measure empirically with data collected from the certificated social enterprises in South Korea. Furthermore, it identifies the antecedents to the conditions under which the centrality of both a social welfare logic and a commercial logic is high or low. In addition, it includes relevant moderating conditions. Below, I 
review prior research on competing institutional logics, social enterprises' centrality of competing logics, stakeholder theory, and imprinting as a perspective.

\section{Background and Literature Review}

\section{Social entrepreneurship as a field with permanent competing institutional}

logics. Although there are several important theoretical and empirical issues regarding the identification of social enterprises, primarily because the meaning of social entrepreneurship varies across people, time frames, and countries (Teasdale, 2012), social entrepreneurship has its roots basically in both the field of entrepreneurship (for-profit) and public (non-profit) organization (Miller \& Wesley, 2010). More specifically, there are at least four ways to define social entrepreneurship (Hoogendoorn, Pennings, \& Thurik, 2009): (1) the innovation school, (2) the social enterprise school, (3) the Emergence of Social Enterprise in Europe (EMES) approach, and (4) the United Kingdom (UK) approach. Of these four perspectives on social enterprises, the first two come from an American tradition; whereas, the latter two are based on European tradition. The identification of social enterprises varies across the four different schools of thought. For example, from the social enterprise school, a social enterprise is a non-profit organization with earned-income activities. On the other hand, the innovation school and the UK approach suggest that social enterprises can acquire either a nonprofit legal status or a for-profit status (Dees \& Anderson, 2006).

Regardless of the definition of social entrepreneurship, however, there is general agreement that social entrepreneurial organizations engage in both socially and financially motivated activities (Dart, 2004). That is, social enterprises lie somewhere between "solely focused on profit maximization" and being "purely social mission 
oriented" (Alter, 2004; Dees, Emerson, \& Economy, 2002). This mixture of motives can be also described as having a "double bottom line" (Emerson \& Twersky, 1996). This tendency is also apparent in the following motto: "We don't hire homies to bake bread; we bake bread to hire homies," which is from Homeboy bakery, first launched by Homeboy Industries in 1992. This business not only helps former gang members, but also competes with traditional for-profit firms. Hence, it seems reasonable to assume that mottos like this one could be used by other social entrepreneurial organizations that combine both a social mission and a profit motive.

Therefore, institutional scholars have described social entrepreneurial organizations as examples of organizations embedded within a field where long-term competing logics exist (Battilana \& Dorado, 2010; Doherty, Haugh, \& Lyon, 2014; Jay, 2013; Pache \& Santos, 2013). Institutional logics refer to "[t]he socially constructed, historical pattern of material practices, assumptions, values, beliefs, and rules by which individuals produce and reproduce their material subsistence, organize time and space, and provide meaning to their social reality" (Thornton, 2004: 69). An institutional logics perspective can also be understood as broader cultural beliefs and rules that guide decision-making (Friedland \& Alford, 1991; Lounsbury, 2008: 350). Some fields utilize two or more competing institutional logics. As examples, within American medical schools, there is a continuous contest between a science and a care logic (Dunn \& Jones, 2010). Also, mutual funds exhibit both a trustee logic and a performance logic (Lounsbury, 2007). In addition, among higher education publishers there are two types of competing institutional logic: a market logic and an editorial logic (Thornton, 2002). 
As Pache and Santos (2013) described, social enterprises permanently operate using two competing institutional logics: a social welfare logic, which guided their activities to interact with public social services and a commercial logic, which led them to rely on commercial customers and industrial partners in order to survive. Thus, many social enterprises maintain dual commitments to focusing on profit-seeking activities, as well as on commercial activities in order to achieve their social mission. In other words, social enterprises respond simultaneously to both a social welfare logic and a commercial logic.

Scholars have advised, seemingly without foundation so far, that both logics should be at the core of the operations and functioning of social enterprises. According to them, ideally social enterprises will be similarly committed both to their social mission and to their economic goals (Mair, Battilana, \& Cardenas, 2012). The dominance of either a social welfare logic or a commercial logic could threaten the legitimacy as well as the survival of social enterprises. For example, if a social enterprise utilized a social welfare logic, it might be criticized for "playing" at business (Chapman, Forbes, \& Brown, 2007), or for "philanthropic amateurism," defined as voluntary organizations relying too much on unqualified amateurs (e.g. volunteers) (Anheier, 2005; Murray \& Dollery, 2005; Salamon, 1987). The excessive dominance of a social welfare logic could jeopardize the survival of a social enterprise. On the other hand, when a commercial logic is given priority over a social logic, it is often criticized for succumbing to "mission-drift," defined as a diversion of energy and effort away from a social mission (Jones, 2007:30; Mair, Battilana, \& Cardenas, 2012; Mersland and Strøm, 2010; Weisbrod, 2004). Furthermore, the predominance of a commercial logic leads organizations to become for- 
profit firms, not social enterprises (Yunus, 2011). Consequently, many scholars have assumed that a social enterprise can best accomplish its mission and economic performance when its social welfare logic and a commercial logic contribute equally (Greenwood et al., 2012; Smith et al., 2012).

Contrary to the conventional wisdom, the efforts of incorporating competing logics equally are often strongly associated with internal and external conflicts. Simple blending long-term competing logics inside the organization can generate paradoxes of performing - ambiguous definition of success and failure (Smith \& Lewis, 2011). Battilana and Dorado's (2012) case study illustrates the negative effect of internal tensions on the growth of a social enterprise, which can occur when an organization thoughtlessly incorporates competing institutional logics. Lee (2014) also opined that the incorporation of competing institutional logics exposed social enterprises to external pressures to conform to different institutional logics, which makes it difficult for them to get funded, receive legal status, and achieve their first sales quickly.

A Social enterprise's centrality of competing institutional logics. As described above, the conventional wisdom of incorporating competing institutional logics is not always effective. Positive benefits from incorporating competing institutional logics can be expected only if intractable conflicts are well managed. It implies that social enterprises will incorporate differently a social welfare logic and a commercial logic in order to pursue their dual missions and minimize conflicts. This view emerges from Besharov and Smith's (2014) introduction of the centrality of competing institutional logics. Accordingly, although scholars in social entrepreneurship encourage a social enterprise to maintain competing institutional logics, organizational functioning may not 
be equally influenced. If social enterprises utilized both logics in the same proportions for their core operations or strategies, centrality would be high. On the other hand, if they gave priority to one logic over another logic, centrality would be low. Although general statements about incorporating a social welfare logic and a commercial logic by social enterprises have assumed that the centrality of competing institutional logic should be high in social enterprises, social enterprises can incorporate varying degrees of centrality for both their social-welfare and commercial logics. This means that there can be effective variations in the levels of centrality for social enterprises. In addition, various conditions such as organizational and individual differences can influence the variance in effective centrality across organizations. Therefore, scholars believe that research on social entrepreneurship can be guided by a more nuanced view of the centrality of competing institutional logics (Besharov and Smith, 2014).

\section{Scale development for a social enterprise's the centrality of competing logics.}

Since previous conceptual studies attempted to understand the centrality of competing institutional logics in social enterprises, existing research explicitly or implicitly calls for more systemic investigation of the factors that enhance or diminish the centrality of institutional competing logics (Besharov \& Smith, 2014; Mair, Battilana, \& Cardenas, 2012; Pache \& Santos, 2013). Nonetheless, an appropriate scale to measure the centrality of competing institutional logics in social enterprises is not available in the literature. In particular, previous studies have assumed that it is difficult to directly measure institutional logics because of their observable nature (Edelman 1990; Fligstein, 1985, 1987; Fligstein \& Brantley, 1992; Ruef \& Scott, 1998; Thornton \& Ocasio, 1999). Scholars have used historical analysis of vocabularies or other proxies to capture 
institutional logics (Dunn \& Junes, 2010; Lounsbury, 2007; Thornton \& Ocasio, 1999), instead of developing relevant measure for assessing institutional logics at the organizational level. Lack of relevant dimensions and constructs of the centrality of competing logics in social enterprises can lead to paucity of empirical efforts for social entrepreneurship. Therefore, I will now review other analogous constructs, terms, or theories, which are included in three independent research areas: (1), work-family interface, (2) organizational ambidexterity, (3) organizational attention. Each of these provides a similar theoretical framework for social-commercial-logic, which help us to develop the measure of the centrality of competing logics.

First, social entrepreneurial organizations engaging in both a social welfare logic and commercial logic are similar to individuals who maintain their work and family (Marks \& MacDermid, 1996). Building on role theory (Aneshensel \& Pearlin, 1987), conflict theory (Zedeck \& Mosier, 1990), and the research of resource drain (Edward \& Rothbard, 2000), the main stream of the research on the work-family interface has assumed that people have a fixed amount of resources to be allocated to their different roles (Rothbard, 2000). After acknowledging a resource trade-off, it suggests that level of the centrality of competing logics is dependent upon varying degree of inputs such as time, involvement, and commitment to distinct roles (Kirchmeyer, 2000).

Second, it may also be useful to review ambidexterity because scholars have argued that such competing logics are equivalent to the idea of trade-off activities such as exploitation and exploration (Greenwood et al., 2011, p.351). Ambidextrous organizations simultaneously exploit ways of improving and refining products/services to meet the demands of existing markets (cf. Mueller, Rosenbusch, \& Bausch, 2013, p.1610; 
Benner \& Tushman, 2003) while they are also exploring sources of new knowledge, searching, experimenting, and innovating (March, 1991). The ambidexterity literature assumes that exploitation and exploration are discrete choices (e.g., He \& Wong, 2004; Jansen, Bosch, \& Volberda, 2005), which require competition for scarce resources (Lavie, Stettner, \& Tushman, 2010). Although there are universally accepted processes and scales for capturing ambidexterity, scholars measure exploration and exploitation separately; then, they assess the relative magnitudes of exploration and exploitation (He \& Wong, 2004; c.f. Cao, Gedajlovic, \& Zhang, 2009). Since the social enterprise's centrality of competing logics is associated with the relative importance of social logics and commercial logics in social enterprises, following the approach of the difference between exploitation and exploration that is used by He and Wong (2004) would be appropriate for developing the scale of the centrality of competing logics.

Third, although institutional logics are unobservable, they guide important issues to which decision makers in organization should attend (Ocasio, 1997). Institutional logics influence the overall behavior within a firm by directing organizational attention, defined here as "the distinct focus of time and effort by [a] firm on a particular set of issues, problems, opportunities, and threats and on a particular set of skills, routines, programs, projects, and procedures" (Ocasio 1997, p 188). Therefore, it is possible that social welfare logics and commercial logic can be regarded as organizational attention to social welfare issue and commercial issue, respectively because it assume that attention to social issues can well represent the social welfare logic; whereas, commercial issues represent the commercial logic (c.f., Pache \& Chowdhury, 2012). 
In summary, a social enterprise's centrality of competing institutional logics assumes that it is limited in scope by boundary conditions, which are drawn from the perspectives discussed above. First, competition for resources to respond to a social or commercial logic is inevitable. Second, the amount of inputs such as time, commitment, for both a social and commercial logic can determine the importance to both logics inside organizations. Third, the centrality of competing logics is assessed by the relative magnitudes of a social-welfare logic and a commercial logic. Forth, a social-welfare logic and a commercial logic could be constructed by attention to each logic.

Stakeholders on the centrality of competing institutional logics. My dissertation, therefore, examines the conditions under which the centrality of competing institutional logics is higher or lower, especially from the view of stakeholders. Stakeholders are "any group or individual who can affect or be affected by the achievement of [a] firm's objectives" (Freeman, 1984:46). Although different organizations may claim different groups as key stakeholders due to this broad definition (Phillips \& Reichart, 2000; Ryan \& Schneider, 2003), Freeman's (1984) they typically include shareholders, employees, customers, government bodies, and community/charitable groups (Agle, Mitchell, \& Sonnenfeld, 1999). Central to stakeholder theory is that a firm is the locus of its relationships with stakeholders (Freeman, 1984; c.f., Parmar, et al., 2010). Similarly to agency theory, stakeholder theory also assumes an efficient market and views a firm as a nexus of contracts. Thus, it presumes that if a firm succeeds in effectively managing its complicated relationships with stakeholders, its welfare can be maximized (Harrison \& John, 1996; Harrison, Bosse, \& Philips, 2010; Walsh, 2005). In this regard, Harrison and his colleagues (2010) argue that managing-for-stakeholders enables a firm to have more 
nuanced information about a stakeholder's utility functions, which makes it possible to achieve a competitive advantage. This is known as the stakeholder value maximization view or the instrumental approach.

In fact, a distinct feature of social entrepreneurship is the "satisfaction of multiple stakeholders" (Lumpkin et al., 2013), mainly because they are the most influential in determining a firm's dominant logic. In consideration of “organizations as complex entities composed of various groups promoting different values, goals, and interests" (Greenwood \& Hinings, 1996; Pache \& Santos, 2010: 459), responses to competing logics can be influenced by an organization's associations with both external and internal stakeholders. Pache and Santos (2010: 458-459) explicitly argued that institutional demands can be conveyed by (1) "actors located outside [an] organization who disseminate, promote, and monitor [these demands across a] field," and by (2) "staff members, executives, board members, or volunteers who adhere to and promote practices, norms, and values that they have been trained to follow or have been socialized into." Therefore, generally, a firm's responsiveness can be understood as a reaction to specific requests from stakeholders (David, Bloom, \& Hillman, 2007; Eesley \& Lenox, 2006). Because of its importance, scholars have also called for research about integration between social entrepreneurship and stakeholder perspective (Moss, Short, Payne, \& Lumpkin, 2011).

In sum, a stakeholder perspective is an appropriate framework to analyze how social enterprises utilize competing institutional logics inside an organization. In other words, a more nuanced understanding of the centrality of both a social welfare logic and commercial logic requires a stakeholder framework. 
Intra-stakeholder heterogeneity perspective. Utilizing a stakeholder perspective as a framework, this dissertation focuses more on intra-stakeholder heterogeneity, which is defined as the degree of difference with respect to a common attribute $X$, such as demographics and preference within primary stakeholder groups (c.f. Harrison \& Klein, 2007; Kassinis \& Vafeas, 2006). Although stakeholder research has identified distinct stakeholder segments, such as customers, employees, and suppliers, scholars have also suggested investigating the differences within each stakeholder group. For example, Harrison and Freeman (1999) argue that meaningful typologies can also exist within group stakeholders, which is known as intra-stakeholder heterogeneity (Fassin, 2008; Winn, 2001; Kassinis \& Vafeas, 2006), referring to the degree of variance in accordance with a common attribute $X$, within primary stakeholder groups (Kassinis \& Vafeas, 2006). It is based on the acknowledgement that "all the stakeholders within a group are not equal" (Fassin \& Gosselin, 2011, p.175). To understand the centrality, it is necessary to take a closer look at intra-stakeholder heterogeneity. Clearly, there are meaningful differences within each stakeholder group that can affect the centrality of competing logics in social enterprises.

There are primarily two reasons why intra-stakeholder heterogeneity is important in this dissertation. First, the internal representation of competing demands comes from internal and external stakeholders. In fact, there are high degrees of heterogeneity within group stakeholders. Each member embedded in a different logic is likely to represent his or her demands differently, which influences the shaping of organizational responses. For example, Kassinis and Vafeas (2006) show that heterogeneous environmental preferences within community stakeholders lead to different outcomes and levels of toxic emissions 
from firms. Specifically, plants related to community stakeholders with a stronger preference for the environment tend to reduce their toxic emissions more than those whose community stakeholders have weaker environmental preferences. This shows that organizational responses are not the result of the pressure from different groups of stakeholders, but the result of the pressure from certain kinds of intra-sub groups across each stakeholder group. Hence, internal stakeholder differences embedded in either a social-welfare logic or commercial logic are likely to be associated with different levels of power regarding a social enterprise's managerial responses. It further impacts the level of centrality for both a social-welfare logic and a commercial logic

Second, actors embedded in different logics within group stakeholders are also associated with their different levels of motivation for participating in social entrepreneurship. Motivational heterogeneity with within-group stakeholders captures the relevant variations in response to a social or a commercial logic. In fact, the most fundamental stakeholder motivations are not the same. Recently, applying social psychology and behavioral economics to stakeholder theory, Bridoux and Stoelhorst (2013) argued that potential stakeholders are comprised of self-regarding and reciprocal (pro-social) behavior. These heterogeneous motives distinguish their behavior as well. For example, self-regarding stakeholders are only concerned with personal benefits and their costs; whereas, reciprocators are willing to cooperate voluntarily (Bridoux \& Stoelhorst, 2013). If members within a particular stakeholder group are primarily comprised of pure altruists whose motivations are altruism, not serving their own selfinterests, one would expect that the pressure from this group could encourage a social enterprise to respond to a social-welfare logic more predominantly than a commercial 
logic. It is particularly meaningful to consider motivation as an important dimension of heterogeneity for within-group stakeholders. Motivation is one of the most important factors that encourage actors to be involved in social entrepreneurship. In particular, prosocial motivation, defined here as the "desire to expend effort to benefit other people" (Batson, 1987; Grant, 2008, p.49), has been regarded as one of the important triggers for involvement in entrepreneurship. Recently, for example, Miller et al. (2012, p.630) provided an in-depth view of how pro-social motivation and compassion encourage social entrepreneurship.

In sum, the centrality of competing institutional logics can be influenced by the internal structure of power within each stakeholder group. Variations in the power structure, due to the composition of each stakeholder group, can exert different influences on the variation in the centrality of competing institutional logics. Although prior research implicitly suggested that considering heterogeneity in a primary stakeholder could be promising for understanding the centrality of competing institutional logics, much less attention has been paid to how heterogeneity within a stakeholder group could impact the centrality of competing institutional logics

A social entrepreneur as an imprinter. This dissertation also introduces a social entrepreneur as a key to the centrality of competing logics. The effects of a social entrepreneur on the centrality of competing institutional logics inside a social enterprise can be examined from an imprinting perspective. An imprinting perspective in organization studies emerges from Stinchcombe (1965) who described organizational structures as reflections of the environmental or industrial conditions at the time in which organizations were founded. In other words, founding conditions have a long-lasting 
impact on the structure, strategy, and processes of organizations. Once the structure of an organization is established, it persists over time despite environmental changes.

Stinchcombe's imprinting hypothesis has evolved into several researchers identifying the effects of founders on the processes, practices, strategies, structures, or culture of the organizations that they found (Baron, Hannan, \& Burton, 2001; Boeker, 1989; Burton, Sørensen, \& Beckman, 2002; Johnson, 2007; Kimberly, 1979; Kimberly \& Bouchikhi, 1995; Phillips, 2002; also see the review of Marquis \& Tilcsik, 2013; Simsek, Fox, \& Heavey, 2015). In this regard, a founder is viewed as an "imprinter;" whereas, the organizations that he or she founds is regarded as "imprinted." For example, Baron, Burton, and Hannan (1999, p.532) argue that “"'[a] founder's blueprint likely 'locks in' the adoption of particular structures."

Scholars have explained a founder's imprinting effects on an organization through four mechanisms (Kriauciunas \& Kale, 2006; Nelso, 2003). First, an organization is strongly influenced by its founder's preferences. For example, Kolympiris, Kalaitzandonakes and Miller (2015) show that a founder's professional experience is the strongest factor for a firm's location choice. They examined the several factors that influence a firm's location choice for 187 biopharmaceutical companies founded by 275 academic entrepreneurs, defined as "university faculties that engage in entrepreneurial activity ” (Di Gregorio \& Shane, 2003, Kolympiris, Kalaitzandonakes, \& Miller, 2015; Lockett et al., 2005). According to their analysis, academic entrepreneurs at a later stage of their academic careers are more likely to avoid starting their firms on campus; whereas, those at an earlier stage of their academic careers prefer an on-campus location to offcampus or outside campus location. 
Second, an organization is a reflection of a founder's vision or identity. For example, from investigating two UK retailing companies both founded during the 1880s, Harris and Ogbonna (1999) found that there were similarities between their original and current strategies for both companies. They explained that a founder's vision and initial strategy created a strategic legacy which continues to exist to date, leaving a significant impact on the current strategy of the focal organization. Thus, a founder's identity plays a role in shaping an emerging organization (Fauchart \& Gruber, 2011; Kimberly, 1979; Whetten \& Mackey, 2002). In a longitudinal study on the development process of new medical schools, Kimberly (1979) showed that a Dean's view and vision about learning medicine determined the curriculum of the schools. In the social entrepreneurship context, a similar result has been reported. In their survey of 162 Israeli social enterprises, Ruvio and Shoham (2011) demonstrated that a social entrepreneur's personal motivation has an impact on the strategic choices of social enterprises.

Third, founders may possess a more significant ownership stake in their organizations than any other stakeholders (Boeker \& Karichalil; 2002; Daily \& Dalton, 1992; Rubenson \& Gupta, 1996). In a sample of 468 IPOs (269 IPOs undertaken by founder-CEOs; 172 IPOs by non-founder CEOs), Fattoum and Delmar (2012) indicated that founder-CEOs retained more equity than non-founder CEOs. In addition, founder CEOs were significantly less likely to attract venture capitals or outside equities than non-founder CEOs. Similarly, Jain and Tabak (2008) also showed that founder-CEOs were more likely to occupy CEO and chairman position on boards of directors at the same time than non-founder CEOs. 
Forth, an organization can be viewed as an extension of its founder because an organization is a product of a founder's psychological commitment or psychological ownership. Founders are likely to possess stronger psychological attachment than nonfounder CEOs (Pierce, Kostova \& Dirks, 2001). Thus, it appears that social entrepreneurs, as founders of social enterprises, may have substantial influence upon the structures, processes, or strategies of the social enterprises that they founded. From the discussion above, I infer that their founders, who are social entrepreneurs, should influence the centrality of the competing social-commercial logics inside social enterprises.

Social entrepreneurs and the centrality of institutional competing logics. From the above discussion, it is also important to understand how a social entrepreneur influences the centrality of competing institutional logics. First, social entrepreneurs are important actors who determine how organizations respond to competing logics. These actors are analogous to "institutional agents" (Kim, Shin, Oh, \& Jeong, 2007), “institutional entrepreneurs" (DiMaggio, 1988), "institutional champion” (Haveman \& Rao, 1997), or "institutional actors" (Scott, Ruef, Mendel, \& Carronna, 2000). Kim et al., (2007: 289) explain that "[i]nstitutional agents are individuals or groups who willingly invest their resources, time, effort, and power in promoting a particular institutional logic along with organizational forms and practices that reflect that logic."

Second, a social entrepreneur must interpret strategic issues. Sense-making by top managers has been critical to organizational outcomes due to the complexity of the environment (Dutton \& Duncan, 1987; Thomas, Glark, Gioia, 1993). When strategic issues are evaluated within organizations, issue valences, such as whether information is positive or negative, a threat or an opportunity, mediate responses by decision makers 
(Denison, Dutton, Kahn, \& Hart, 1996; Jackson \& Dutton, 1988; Thomas \& McDaniel, 1990). The way decision makers evaluate the valence of an issue can affect differences in strategic actions (Bartunek, 1984; Gioia \& Chittipeddi, 1991). Therefore, it is worth considering how the extent to which differences in evaluation by a social entrepreneur could influence the centrality of competing institutional logics.

Third, a social entrepreneur as a decision maker plays a role in deciding resource allocation, which also impacts the strategic direction of a social enterprise because a firm's strategic actions are by-products of choices made by decision maker(s) (Dean \& Sharfman, 1996; Lovallo \& Sibony, 2010). For example, extant research has shown that a firm's outcomes occur, not because of resource endowment differences, but because of different usages of endowed resources (Amit \& Schoemaker, 1993; Peteraf \& Bergen, 2003). Recently, Klingebiel and Rammer (2014) also confirm the importance of the heterogeneity of resource allocation, demonstrating how different resource allocation strategies impact variation in innovation performance. Hence, it is important to understand how the extent to which a social entrepreneur distributes resources within an organization could differentiate the centrality of competing institutional logics. The degree of the centrality of competing logics would vary in accordance with a social entrepreneur's decisions on resource allocation within an organization (Bower \& Gilbert, 2007; Mairesse \& Mohnen, 2002). 


\section{Research Questions and Research Objectives}

Research questions. This dissertation attempts to answer the following research questions.

1. How and to what extent is the centrality of competing institutional logics in a social entrepreneurial organization influenced by heterogeneity within each important stakeholder?

2. How and to what extent is the centrality of competing institutional logics in a social entrepreneurial organization influenced by a social entrepreneur?

Research objectives. Focusing on the research questions above, this dissertation has the following objectives.

1. Consider both theoretically and empirically the centrality of competing institutional logics within social enterprises.

2. Offer the validated instrument to measure a social enterprise's centrality of competing logics.

3. Identify the relevant dimensions of heterogeneity within each important stakeholder group (e.g. shareholder, customer, and employee).

4. Examine the potential direct effects of heterogeneity in each of the three stakeholder groups (shareholder, customer, and employee) on the centrality of competing institutional logics.

5. Identify and examine the attributes of social entrepreneurs, which directly influence the centrality of competing institutional logics.

6. Identify any other attributes of a social entrepreneur as contingent conditions of competing institutional logics inside social enterprises. 
Accordingly, this dissertation consists of two studies. As depicted in Figure 1, study one attempts to investigate the heterogeneities within each stakeholder group that are hypothesized to impact the centrality of competing logics. The second study explores the factors associated with a social entrepreneur that also can be hypothesized to influence the centrality of competing logics. Figure 1 presents a theoretical model describing the proposed conceptual model.

\section{Figure 1. Conceptual Model for Hypotheses Testing}

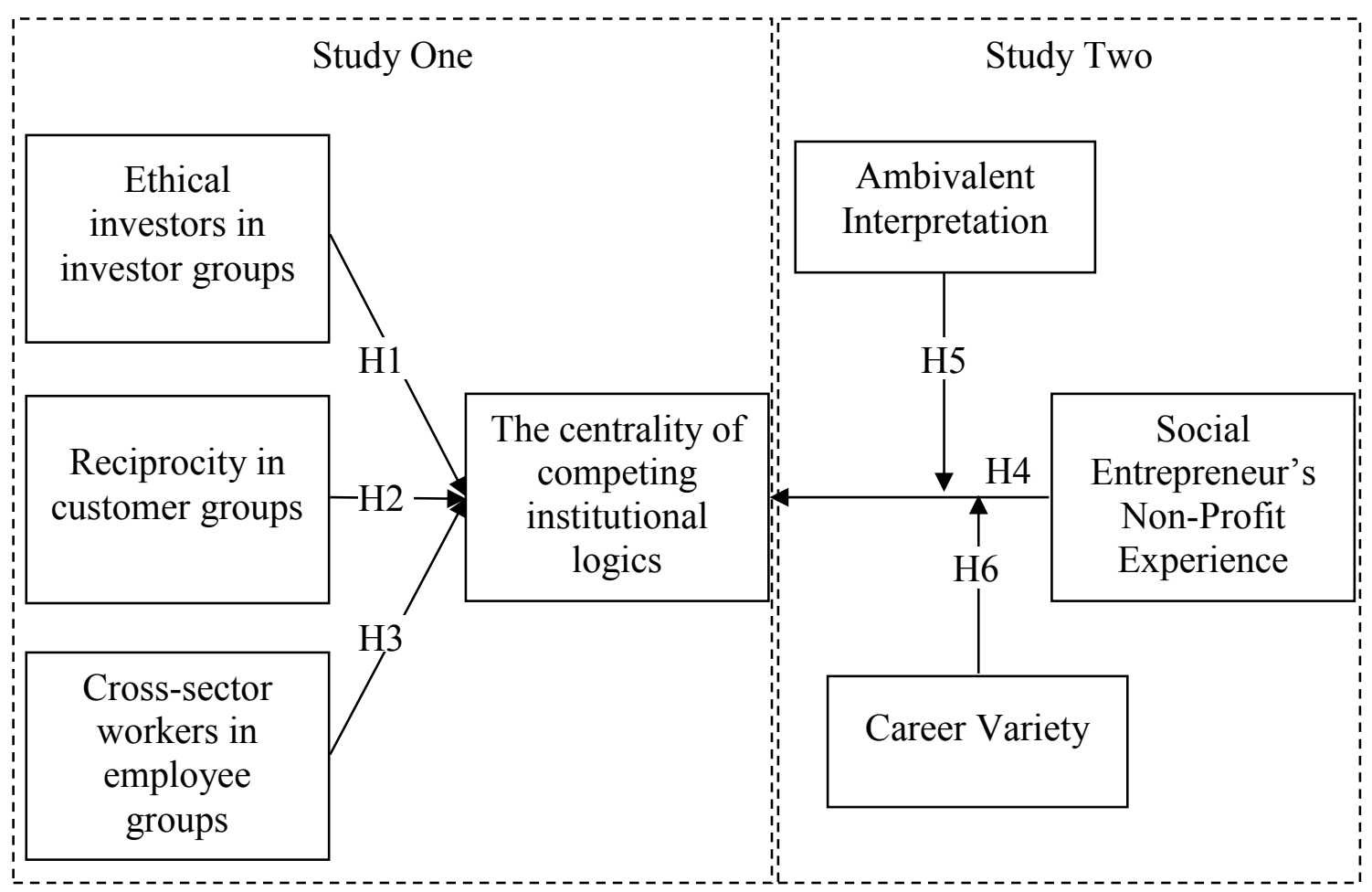

\section{Significance of the Study}

First, this dissertation offers a validated instrument to measure a social enterprise's centrality of competing logics. Since the conceptual construct of the centrality of competing logics is recently identified in institutional logics scholarship (Besharov \& Smith, 2014), such an instrument in the social entrepreneurship field has not 
been available yet. The dissertation provides empirical evidence that a social enterprise's centrality of the centrality of competing logics and its two dimensions - a social welfare logics and a commercial logic - are reliable and validated through the data collected from the certified social enterprises in South Korea. Therefore, this dissertation can offer useful guidance for scholars are interested in conducting the research on the centrality of competing logics in social enterprises.

Second, this dissertation analyzes social enterprises through the lens of an institutional logics perspective (Battilana \& Dorado, 2010; Pache, 2011; Pache \& Santos, $2010,2013)$. Because social entrepreneurial organizations prefer to combine marketbased organizing (e.g., a commercial logic) with charity-based organizing (e.g., social welfare logic), scholars have applied an institutional logics perspective to an entrepreneurial social context (Battilana \& Dorado, 2010; Pache \& Santos, 2013). I extend this research stream by employing both a stakeholder perspective and an imprinting perspective. In doing so, I attempt to connect four distinct research areas together, which are: (1) social entrepreneurship, (2) institutional logic, (3) intrastakeholder perspective, and (4) imprinting perspective.

Third, my dissertation contributes to the literature on intra-stakeholder heterogeneity (Fassin \& Gosselin, 2011; Harrison \& Freeman, 1999; Kassinis \& Vafeas, 2006; Winn, 2001). By examining its relevant dimensions for three types of stakeholders (shareholders, customers, and employees), I am able to provide a more contextualized explanation of the centrality of competing institutional logics.

Fourth, my dissertation introduces to social entrepreneurship research an imprinting perspective as the theoretical foundation. By doing so, it extends our 
understanding of the effects of the attributes of social entrepreneurs with regard to the centrality of competing institutional logics. Beyond motivational factors such as compassion (Miller et al., 2012), social entrepreneurs can play a role in interpreting strategic issues (Thomas, Glark, Gioia, 1993) and resource allocation (Lovallo \& Sibony, 2010). By identifying a social entrepreneur's specific attributes as either antecedents or moderators, I develop and examine a number of testable hypotheses.

Fifth, this dissertation contributes to the literature by adding empirical evidence based on large-scale data. Despite the growing interest in social entrepreneurship, it has suffered from a lack of theoretical development and empirical testing. Progress in the field of social entrepreneurship requires rigorous statistics using larger scale databases and reliable measurement (Short, Moss, \& Lumpkin, 2009). Hence, this dissertation not only collects large-scale data for social enterprises in South Korea, but also introduces many interesting testable hypotheses.

\section{Organization of the Dissertation}

My dissertation is organized as follow. Chapter 2 (study 1) reviews previous studies on the theoretical development for the relationship between intra-stakeholder heterogeneity and the centrality of competing institutional logics. Also, Chapter 2 develops testable hypotheses regarding the specific characteristics within three important market stakeholders: shareholder, customer, and employee groups. Chapter 3 (study 2) reviews the effects of a social entrepreneur's prior work experience on an organization. In addition, Chapter 3 theorizes a relationship between a social entrepreneur's non-profit experience and the centrality of competing logics. Furthermore, it examines a social entrepreneur's attributes as potential moderating factors for the focal relationship. 
Specifically, it identifies two important attributes of a social entrepreneur as moderators: ambivalent interpretation and a social entrepreneur's career variety. Chapter 4 explains the methodological approaches, including the empirical setting, data collection, operationalization of variables, and analytic method for both study one and study two.

Chapter 5 lists the analysis and results of hypotheses tastings detailed in Chapter

4.Chapter 6 interprets the results and discusses the theoretical and practical implications. 


\section{CHAPTER 2: THEORY AND HYPOTHESIS- STUDY ONE}

\section{Intra-stakeholder Heterogeneity and the Centrality of Competing Logics}

This dissertation identifies the effects of intra-stakeholder heterogeneity on the centrality of competing institutional logics, specifically by focusing on the extent to which characteristics within each stakeholder group lead social enterprises to enhance or lessen the centrality of competing institutional logics. Resource dependency theory (Pfeffer \& Salancik 1978) supports a proposed notion that within-group heterogeneity influences the centrality of competing logics.

A Resource Dependence Perspective. Because resource environments surrounding organizations are critical to a firm's institutional logics (Thornton, Ocasio, \& Lounsbury, 2012), a social enterprise's responsiveness is contingent upon its degree of dependence on critical stakeholder resources. In other words, a social enterprise's response to social-commercial logic is directly or indirectly influenced by the degree to which it depends on stakeholder resources (Frooman, 1999). This perspective is associated with resource dependence theory (Pfeffer \& Salancik, 1979). Resource dependence theory assumes that organizations are open systems depending on critical resources (Ulrich \& Barney, 1984). Because of this dependence, strategic responses should be understood within the context of a resource environment (Pfeffer \& Salancik, 1978). Basically, organizations respond to stakeholders in order to manage or reduce their dependencies (Pfeffer \& Salancik 1978; cf. Hillman, Withers, \& Collins, 2009). 
Social enterprises share an even more intense concern for resource mobilization because they often operate in environments where access to quality resources at reasonable costs is elusive (Desa \& Basu, 2013). Concerns about resource availability suggest that stakeholders who control the resources on which social enterprises depend exert a strong influence on the social-commercial logic in which they are embedded. Following this reasoning and findings, a social enterprise's responsiveness to competing logics is mainly predicated on its differing levels of dependence on particular stakeholder resources. Thus, a resource dependence perspective implies that social enterprises are likely to give precedence to a particular logic embedded in specific stakeholders who hold the critical resources.

Considering the concept of intra-stakeholder heterogeneity (Fassin, 2009; Winn, 2001) - not all the stakeholders within a same group of stakeholder are same-however, stakeholder subgroups can elaborate further on the levels of dependency, which has impacts on social enterprises' centrality of competing logics. For example, Fassin and Gosselin (2011) argued that many different subgroups within investors group have completely different objectives. In investigating the case of bankruptcy of Fortis, a European bank, they found that there are various subgroups within investor stakeholders such as long-term, short-term investors, small individuals, and large hedge funds. In addition, different subgroups of investor stakeholders gave pressures of different agendas and priorities. Similarly, Kassinis and Vafeas (2006) analyzed the pressures of stakeholder groups on firm environmental performance, and demonstrated that not only is there the internal heterogeneity of stakeholder groups, but also that different levels of resource dependence within group stakeholders are associated with different levels of 
focal firm activities. Specifically, they showed that firms perceive higher pressures to reduce their pollution level if they are located in wealth communities than poor communities. It is noted that subgroup regarding income levels within community stakeholders plays a significant role in improving firm environmental performance.

From the previous discussion, specific stakeholder subgroup can determine the relative dependencies of the resources that the social enterprises feel scarce, which shapes the firms' responsiveness. Thus, I posit that social enterprises are more likely to have higher level of centrality of competing logics when they have the larger portion of subgroup associated with both social and commercial logics within each stakeholder. When the portion of subgroup attached in both logics within each stakeholder is high, social enterprises may have a stronger incentive to incorporate both logics at the core of organizational functioning in order to reduce the pressures generated from the subgroup embedded in both logics. This perspective, therefore, proposes that identifying the subgroup associated with both social and commercial logics within each stakeholder groups would be the key to enhancing the high level of centrality of competing logics inside social enterprises.

In order to identify the specific subgroup embedded in both logics; this dissertation focuses on market stakeholders such as investors, customers, and employees, rather than non-market stakeholders. Generally, stakeholders can be viewed as members of two groups, market stakeholders and non-market stakeholders (Baron, 1995; Stevens et al., 2005). Market stakeholders are the groups whose activities are associated with firms via economic transactions (Cummings \& Doh, 2000). Market stakeholders consist of shareholders, employees, customers, and even rivals. On the other hand, non-market 
stakeholders are regulatory agencies, government, and special interest groups. Because their interactions with firms are not guided by an economic purpose, non-market stakeholders are treated less urgently due to their lack of economic power (Stevens et al., 2005). Market stakeholders, however, are considered to be as salient as primary stakeholders due to their provision of critical resources (Pfeffer \& Salancik, 1978). Therefore, this dissertation will be bounded to the assumption that the roles of subgroups within market stakeholders are more effective on the centrality of competing logics than those within non-market stakeholders. In addition, this dissertation assumes that the portion of subgroup attached in both logics inside social enterprises can be influenced by the influx of social welfare logic within market stakeholders for social enterprises, thereby enhancing the centrality of competing logics for social enterprises.

\section{Figure 2. Study One Model}

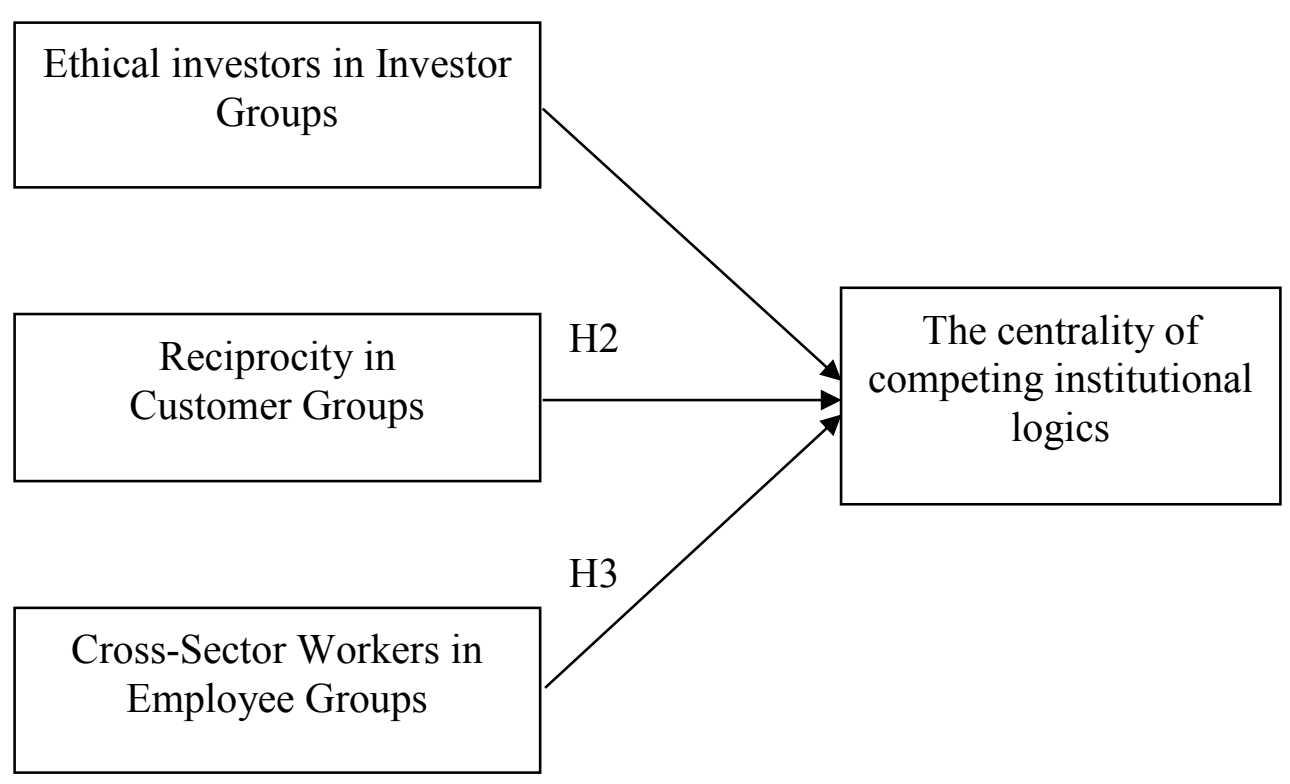


In sum, I suggest that a social enterprise with high in-subgroup associated with both social and commercial logics within each stakeholder may increase the centrality of its competing institutional logics. Moreover, I focus on three market stakeholders: (1) investors, (2) customers, and (3) employees. Figure 2 presents a theoretical model describing the proposed relationships.

\section{Ethical Investor within Investor Stakeholder}

Investors or shareholders are important stakeholders (Freeman, Wicks, \& Parmar, 2004). Investors, as owners of a firm, have a tremendous impact through allocating scarce resources and pressuring managers. When they are not satisfied with managerial behaviors, they are likely to sell their shares (Hoskisson, Hitt, Johnson, \& Grossman, 2002), which jeopardizes the survival of a firm because they are its one of most powerful stakeholders (March \& Simon, 1958). Thus, a firm has strong incentives to understand the interests of shareholders preferentially according to the magnitude of their ownership (Bloom \& Hillman, 2007; Reid \& Toffel, 2009). The importance of understanding the investors or funders is particularly great for social enterprises because social enterprises are heavily depending on wide range of funding sources from various types of investors whose motivations and expectations are also diverse (Austin et al., 2006; Letts, Ryan and Grossman, 1997). Nevertheless, systematic examinations on the relationship between investors' expectations and the centrality of competing logics within social enterprises are scarce. Fundamentally, the important question remains regarding the extent to which investors with various motivations can pressure the social enterprises to increase or decrease the centrality of competing logics. 
A traditional economic perspective has assumed that the primary shareholder objective is profit maximization; a firm has a fiduciary responsibility to its shareholders to protect and promote their financial interests (Bebchuk, 2005; 2006; Eisenhardt, 1989; Hart, 1993). Consequently, a manager's duty is to make decisions to maximize the value of firm's future cash flow (Brealey, Myers, \& Marcus, 1995; Copeland, Murrin, \& Koller, 1994; Friedman, 1962).

However, behavioral finance scholars have challenged the traditional assumption of wealth maximizing investment. According to an investigation by Nagy and Obenberger (1994), more than half of the criteria that affect an investor's decision are unrelated to wealth maximization. Beal, Goyen, and Philips (2005) also assert that some investments are viewed as ethical or socially responsible investment (SRI). The Social Investment Forum, for example, reports that socially responsible investors own $11 \%$ of the assets in the US and 17\% in Europe (Gollier \& Pouget, 2012). Recent studies refer to this special group of investors as ethical investor or socially conscious investors (Mackey, Mackey, \& Barney, 2007; Sandberg, Juravle, Hedesstrom, \& Hamilton, 2009). Ethical investors or socially conscious investors are interested in more than their own wealth maximization. Rather, they also derive other benefits from investment (Lewis \& Mackenzie, 2000). For example, besides maximizing their financial return only, the utility of ethical investment can be maximized by inclusion of different factors such as (1) the fun of participation, (2) the acquisition of an ethical identity, (3) the flow of pleasure (Beal et al., 2005).

The rise of ethical investors whose motivations are not limited by financial returns may increase opportunities for enhancing the centrality of competing logics inside social 
enterprises. First, ethical or socially conscious investors more than likely have a willingness to accept below-market rate returns. For example, Renneboog, Ter Horst, and Zhang (2011) found out that ethical investors are less likely to be concerned about negative returns when they invest in ethical funds. Similarly, according to several experimental studies, investors whose decision frame is expressive in nature are likely to accept the lower financial return from the socially responsible investment choice (Glac, 2009). Webley, Lewis, and Mackenzie (2001) also showed that ethical investors are more likely to keep badly performing ethical funds away from conventional investors. Their acceptance of low financial returns may allow social enterprises to be less dependent upon commercial activities unrelated to their core social value. It is known that if social enterprises should exclusively satisfy the market rate returns of traditional investors, social enterprises are likely to allocate their resources and energies to commercial activities, which diverts the social enterprises away from their social missions (Wang, 2009). It may further decrease the centrality of competing logics. For example, Deeds and Anderson $(2001 ; 2003)$ provide cases of how the domination of private investors with homogenous profit-maximizing objectives could have a negative impact on a social mission. They argue that conventional investors may want social enterprises to heavily engage in commercial activities regardless of an association with a social goal. This process could force social enterprises to abandon a core value. Other scholars are also concerned that unrelated commercial activities with emphasis on earned income generation can be a major source of trade-off between the social and commercial missions in a social enterprise (Foster \& Bradach, 2005; Tuckman \& Chang, 2006). 
Second, as current finance literature on social entrepreneurship has illustrated, ethical investors with low financial return expectations are likely to assign more decision weight to the scalability of an operation (Frumkin, 2003; Moody, 2009). According to a new investment phenomena in the field of social entrepreneurship, ethical investors are associated with a social (impact) investment - defined here as "an investment made into social enterprises and social purpose businesses designed for the purpose of creating social impact" (Hill, 2011, p15), as well as a philanthropic venture capital (PhVC), also known as venture philanthropy -defined here as an intermediated investment in a smallmedium social enterprises with a potential for a high social impact (Scarlata \& Alemany, 2010; Scarlata, Alemany, \& Zakarakis, 2012). These new investors may believe that social value creation and profit generation are not mutually exclusive; rather, scaling the operation of the business will give greater benefits to the society such as creating the jobs for disabled or serving low-cost products/services to the underdeveloped communities (Boschee, 2008; Chell, 2007; Hervieux et al., 2010). For them, a key to philanthropy is "getting tangible results" (Frumkin, 2003; p.9). Thus, although they act as donors, venture philanthropists urge the organizations chosen for support to achieve substantial growth in order to spread the positive social impact as well. Considering the prior discussion, I hypothesize:

H1: A greater proportion of ethical investors within an investor stakeholder will be associated with higher centrality for its competing institutional logics. 


\section{Reciprocity within Customer Stakeholder}

Buyers have the power to persuade a firm to do something (Rudell, 2006).

Basically, like other economic stakeholders, customers are important constituents for the survival of a firm because of cash flow from customers (Henriques and Sadorsky, 1999; Reichheld \& Sasser, 1990). Conventional attention has been directed to the "customer satisfaction" in marketing literatures as well as business magazines. If firms satisfy their customers, this could lead to higher customer loyalty, reduced transaction costs, and lower price sensitivities, which are ultimately positively related with economic returns (Anderson, Fornell, \& Lehmann, 1994; Fornell, 1992). According to traditional transaction-specific view, customer satisfaction has been based on "post-purchase evaluation of product quality given pre-purchase expectations (Anderson \& Sullivan, 1993: 126)."

In contrast, there is a growing view that customers are not only satisfied with the product performance that they purchase, but also concerned with labor conditions (Senser, 1997), environmental friendly practices (Laroche, Bergeron, \& Barbaro-Forleo, 2001; Suchard and Polonsky, 1991), or fair trading (Nicholls, 2010a). For example, it is reported that there is growing number of consumers who are willing to pay more for what they view as ethical products (Memery, Megicks, Angell, \& Williams, 2012: 1284; Mohr \& Webb, 2005). According to ethical consumerism research, UK consumers spent $£ 25.8$ billion a year on ethical shopping in 2004, but $£ 36$ billion in 2009 . Fair trade - "a social movement that aims to set fair prices for products, alleviate poverty, and assist producers" (White, MacDonnell, \& Ellard, 2012: 103) - has also received much attention. The global market for fair trade products was over $£ 2$ billion in 2007 (Nicholls, 2010a). According to 
their Belgian study, De Pelsmacker et al. (2005) showed that consumers are willing to pay $10 \%$ more for fair-trade products. Similarly, Italian customers are willing to pay $9 \%$ more for fair- trade products (Maietta, 2003). A new segment of consumers who consider environmental and social issues when they make purchase decisions also has been noted (Woolverton \& Dimitri, 2010). It is known as lifestyles of health and sustainability, which has an acronym, LOHAS. About $17 \%$ of US consumers in 2006 were classified as LOHAS (Howard, 2008).

A few studies have begun to study social entrepreneurship from the consumers' standpoint. Researchers have recognized that customers affect social enterprises' decision making on allocating their resources either to social or commercial activities in order to create value for their primary customers (Ebrahim, Battilana, \& Mair, 2014). For example, Ebrahim, Battilana, and Mair (2014) argue that social enterprises are likely to experience a prioritization of resource usages toward commercial activities if they serve economic consumers, or target mainly those who can pay for the products or services. It further implies that the buying motivations of intended customers are related to the centrality of social and commercial logics inside a social enterprise.

Among various buying motivations, I would expect that reciprocal motivation, defined as a cultural norm whereby individuals enter into an exchange with the anticipation of the receiving the future benefit (Dawson, 1988), among a consumer stakeholder group inside a social enterprise may affect the determination of the level of centrality of social-commercial logics. Reciprocity is indicative of why consumers are interested in purchasing the goods or services produced by social enterprises. To date, reciprocity has been considered as the compelling factor why people engage in helping 
others (Ames, Flynn, \& Weber, 2004; Blau, 1963). Dawson (1988) argued that people who participate in charity giving are heavily motivated by the belief on the anticipation of receiving personal benefits from charity organizations (Adams, 1965; Dawson, 1988). Similarly, Andreoni $(1989 ; 1990)$ argued that individuals who support any public good are not motivated solely by pure altruism. Rather, two components of (1) a desire to help (or, an altruistic motive), and (2) a personal positive benefits from helping others (an egoistic motive) may drive people to engage in supporting public goods. KoschateFischer, Stefan, and Hoyer (2012) empirically confirm that both altruistic benefits and egoistic benefits such as the improvement of individual reputations can play a role in consumers' positive reaction to companies' donation activity.

Reciprocally motivated consumers may exert social enterprises to not only provide economically qualified products/services, but also achieve the social benefits at the same time. For example, Hibbert, Hogg, and Quinn (2005) show the evidence that consumers who purchase the Big Issue, a street magazine to provide exclusively homeless people with the chance to become a vendor, expect both utilitarian value of magazine and helping dimension of the exchange. Similarly, UK government agencies as public service buyers from social enterprises claim that social enterprises should provide their ability to meet its financial and its social bottom line (Allan, 2005). It further implies that consumers involved in social entrepreneurship may view ideal social enterprises as the organizations or the firms that not only satisfy consumers' desire to help others, but also provide other benefits such as qualified goods and services, reputation, or positive feeling. 
In sum, consumers' reciprocity motivation would be an important dimension of customer stakeholders in social enterprises on enhancing centrality of competing logic. Specifically, I expect that increasing the size of consumers motivated by reciprocity increases the likelihood that social enterprises will enhance both the social and commercial activities without prioritizing one over another.

H2: A greater proportion of customers with high expectations of reciprocity within customer stakeholders will be associated with higher centrality for its competing institutional logics.

\section{Cross-Sector Workers within Employee Stakeholder}

Employees are not only major stakeholders (Clarkson, 1995), but they also influence organizational responsiveness to competing logics because they serve as carriers of the institutional logics into organizations (Battilana \& Dorado, 2012). Social enterprises consist of two broad types of employees--beneficiaries and regular staff. Beneficiaries refer to disabled people or other marginalized workers such as long-term unemployed or people in precarious situations (Ohana \& Meyer, 2010; Spear \& Bidet, 2005). Specially, work integration social enterprises (WISE) normally offer a fixed-term contract and training to survive in the main labor market (Ohana \& Meyer, 2010). On the other hand, regular staff employees are permanent and responsible to assist beneficiaries as well as do administrative tasks. This dissertation focuses exclusively on heterogeneity within permanent employees rather than including beneficiaries mainly because permanent employees (hereafter, employees) are competitive human resources for both social mission achievement and economic performance in social enterprises. Although there are numerous dimensions of employee diversity, such as age, ethnicity, and 
education, this dissertation focuses on the prior work background of employees because it relates to employees' attachment to distinct institutional logics, either a social welfare logic or commercial logic.

Employees' prior exposure to either a social welfare logic or a commercial logic due to their prior work experiences can determine their embeddedness in particular institutional logics, which can be translated into the focal organization. This notion is also similar to mainstream research on employees' functional diversity, arguing that prior work experience can determine their belief structure, which leads to different preferences and interpretations of strategic issues (Pelled, Eisenhardt, \& Xin, 1999). In the social entrepreneurship field, Battilana and Dorado's (2012) case study would be the best example. According to their study, one of the microfinance organizations that incorporate both a banking (and finance) logic and a development logic hired employees based on a mix-and-match approach, defined as prioritizing an individual's capabilities in a selection decision. As a result, there were two distinct groups of employees, one with a social-work background and another with a banking background. This example illustrates that employees persist in keeping themselves in particular logic where they have been exposed (Greenwood et al., 2011). In addition, they exert pressure that makes the organization conform to their initial institutional logics. Thus, prior work background for employee-stakeholders appears to be a strong driver, which impacts the ways that social enterprises respond to competing logics.

In this dissertation, I expect that the rise of cross-sector workers who have work experience in both the non-profit and the for-profit sector may enhance the centrality of competing logics inside thesocial enterprises. Although it has been assumed that 
employees in the social entrepreneurship field are regarded as part of a homogenous group who are social-value oriented (Rawls, Ullrich, \& Nelson, 1975), their work values may differ in accordance with prior work experience. Prior embeddedness in different institutional logics can be related to different normative values (Almandoz, 2012; Hirsch, 1997). Recently, de Cooman and his colleagues (2011) compared the work values of employees in not-for-profit service organizations with those of employees in for-profit sectors. Employees in the not-for-profit sector placed a higher value on social service than employees in for-profit sector (de Cooman, Gieter, Pepermans, \& Jegers, 2011). In addition, employees in the not-for-profit sector focused less on their career advancement than those in the for-profit sector. Thus, cross-sector workers are more likely to equip social enterprises with various work values and diverse points of view, which lead social enterprises to avoid dominating competing logic within organizations.

Another feature of cross-workers rests on the notion that those from a diverse background would have more diverse expertise and resources, such as social contacts, outside knowledge, and information (Keller, 2001). Because an employee's prior work experience in different institutional logics could serve as an information-related competitive advantage, this could broaden a social enterprise's strategic options for responding to competing logics. Thus, I propose the following hypothesis:

H3: A greater proportion of cross-sector workers within an employee stakeholder will be associated with greater centrality for its competing institutional logics. 


\section{CHAPTER 3: THEORY AND HYPOTHESIS - STUDY TWO}

\section{A Social Entrepreneur and the Centrality of Competing Institutional Logics}

In this chapter, I introduce a social entrepreneur's non-profit experience as an antecedent of the centrality of competing logics. I also propose a curvilinear relationship between a social entrepreneur's non-profit experience and the centrality of competing logics. Furthermore, I suggest two contingent conditions that will moderate the effects of a social entrepreneur's non-profit experience on the centrality of competing logics

Founder's Prior Work Experience on New Organization. Research of the effects of founders on their new organization has also identified the importance of the prior work experience of founders. Being an entrepreneur is one of the decisions that could place one's career at risk (see Sørensen \& Sharkey, 2014; Carter, Gartner, Shaver, and Gatewood, 2003). Entrepreneurial careers, however do originate from nothing, but come from several different points of departure: (1) school to venture, (2) job to venture, (3) unemployment to venture, (4) home to venture, (5) venture to venture (Vesper, 1980). Among these different paths, the majority of entrepreneurs have experience working for existing organizations (Cooper, 1986). Sorensen and Fassiotto (2011) identify four aspects of why existing organizations matter in the entrepreneurial process. They are knowledge, values, social capital, and opportunities. Existing firms play a role in determining the exposure of individuals to entrepreneurial opportunities and in shaping 
their desire and willingness to engage in entrepreneurship (Carroll \& Mosakowski, 1987; Romanelli, 1989; Schoonhoven \& Romanelli, 2001; Shane, 2000; Thornton, 1999). In addition, individuals develop innovative ideas in existing organizations and learn the practices of how to run an organization (Phillips, 2002, 2005).

Furthermore, a founder's previous work experience may have significant effects on the processes, structures, or strategies of her/his newly founded organization (McKelvey, 1982). Many theoretical arguments, as well as empirical research, have supported this idea mainly because previous job experience is strongly associated with the founders' creation of a vision (Nahapiet \& Ghoshal, 1998), preference (Philips, 2005), identity (Kimberly, 1979), knowledge structure (Beckman, 2006; Fern, Cardinal, \& O’Neil, 2012), social capital (Shane \& Stuart, 2002) prior to starting one's organization. For example, Burton, Sørensen, and Beckman (2002) argue that previous founder job experience shapes in their venture strategies. They investigated a sample of 164 Silicon Valley based companies, and provided the evidence that founders whose previous employment in entrepreneurially prominent firms was more associated with implementing an innovative strategy than those from less prominent firms. Similarly, in the investigation of 431 Silicon Valley law firms, Phillips (2005) learned that founders who had previous work experience at the firms having a woman in a partner position are more likely to promote women into prominent positions in their newly founded law firm than those who worked at the firms having women in subordinate positions. Next, I will develop a set of hypotheses about the relationship between social entrepreneurs' prior non-profit experience and the centrality of competing logics in their social enterprises. In addition, I will explore the potential moderators on the relationship between social 
entrepreneurs' prior non-profit experience and the centrality of competing logics. Figure 3 presents a theoretical model describing the proposed relationships.

\section{Figure 3. Study Two Model}

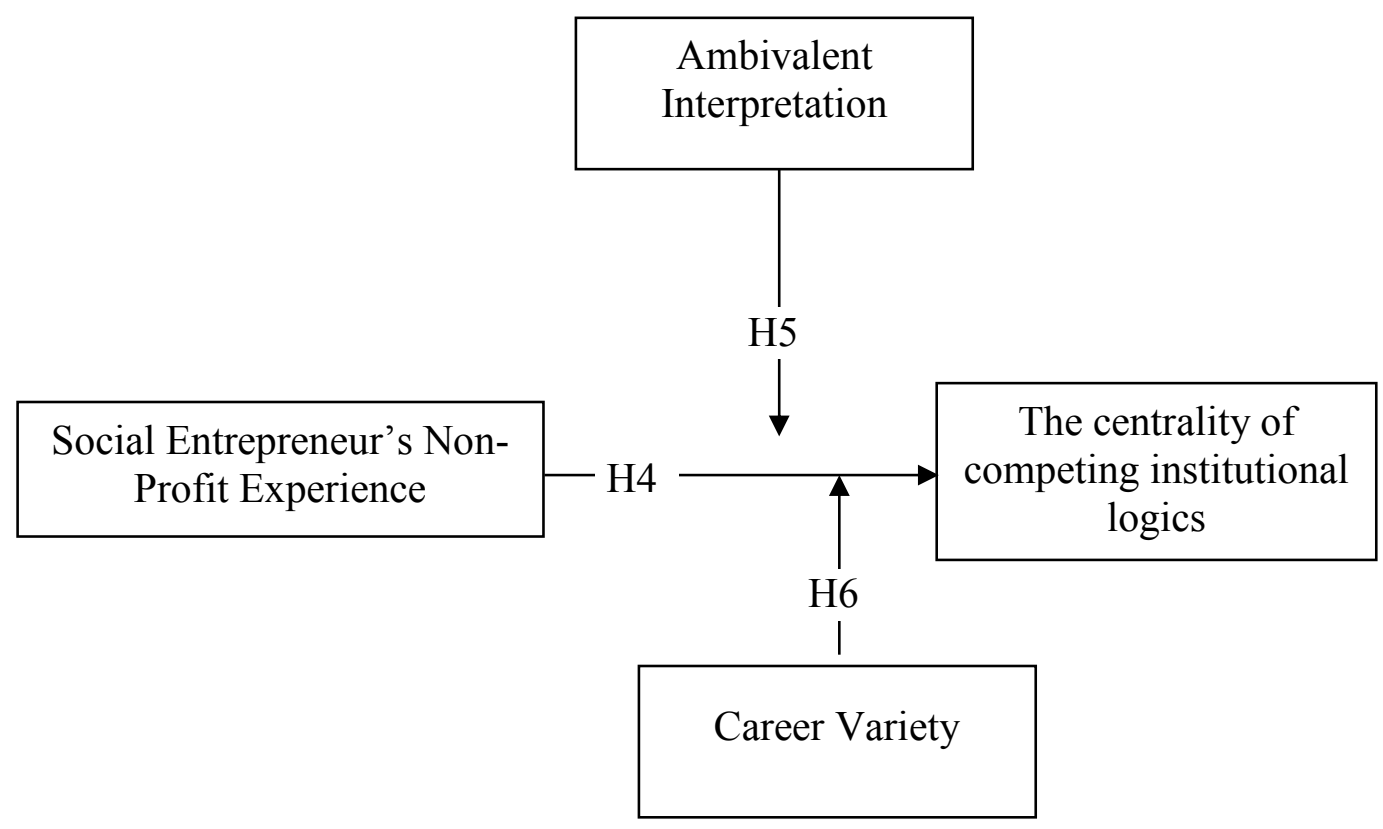

\section{The Curvilinear Relationship Between a Social Entrepreneur's Non-Profit Experience and the Centrality of Competing Institutional logics}

I argue that a social enterprise's centrality depends in part on its founder's nonprofit experience, which I define as the founder's time spent previously working in the non-profit area prior to starting current social enterprise. Although there is no single 
theory that can directly explain the relationship between a social entrepreneur's nonprofit experience and the centrality of competing logics inside a social enterprise, there are several potential explanations why the non-profit experience of a social entrepreneur can positively impact the centrality of competing logics based on motivation, industry specific knowledge, autonomy, and legitimacy.

First, social entrepreneurship derives from prosocial motivation, defined here as a "desire to expend effort to benefit other people" (Batson, 1987; see Miller, et al.,2012). Motivation perspective, therefore, is related to a "preference sorting" mechanism. In other words, it is possible that potential social entrepreneurs prefer purposely to work in non-profit organizations before they start their social enterprises. It suggests that nonprofit organizations may attract individuals who not only place greater value on social responsibility, but also benefit from the satisfaction a working on socially desirable goods and services in non-profit areas. These individuals are more likely to be characterized by conscious self-control to fulfill a core value and their own self-perceived identities (Ryan \& Deci, 2000). This characteristic may help individuals become ideal social entrepreneurs, which could assist their social enterprises to enhance both their social logic and commercial logic through well-defined goal, competence, and self-direction. Not surprisingly, scholars in social entrepreneurship have already shared the assumption that key difference between traditional entrepreneurs and social entrepreneurs is sociomoral motivation via entrepreneurial initiatives (Bacq, Hartog, \& Hoogendoorn, 2014; Nicholls, 2006, Shaw \& Carter, 2007). In sum, individuals with non-profit experience are likely to be equipped with prosocial motivation, which increases the effectiveness of social entrepreneurship. 
Second, a founder's working experience in a similar industry would cultivate specific industry knowledge, which is positively related to organizational outcomes (Becker, 1975; Cohen \& Levinthal, 1990; Delmar \& Shane, 2006). Grichnik et al. (2014) argue that experience helps individuals understand the rules of the industry game. Similarly, non-profit experience allows social entrepreneurs to acquire industry specific knowledge. By definition, the main purpose of social entrepreneurship is to create social value (Thake \& Zadek, 1997). The tasks of social entrepreneurs are (1) addressing social problems; (2) approaching them in innovative ways; and (3) mobilizing the resources (Austin, Stevenson, \& Wei-Skillern, 2006). Because social entrepreneurship is inseparable from social problems, social entrepreneurs with non-profit experience may increase their ability to identify social problems, gather information, and acquire needed resources. In fact, extant studies suggest that prior specific industry experience helps founders grasp consumer needs (Levinthal \& March 1993), identify more opportunities (Gruber, McMillan, \& Thomson, 2008), get more precise information (Landier \& Thesmar, 2009), and improve performance forecasting (Cassar, 2014).

Third, non-profit organizations may provide their employees with the greater autonomy and decision-making discretion in uncertain situations (Borzaga \& Tortia, 2006). It is known that increased work autonomy will expose employees to broader information and to diverse contacts (Dobrev \& Barnett, 2005). Broader exposure through non-profit experience enables potential social entrepreneurs to have a more diverse skill set for entrepreneurship. Empirical study also supported this perspective. In the second panel study of entrepreneurial dynamics (PSED 2), Hopp (2012) learned that a founder's nonprofit experience is significantly associated with entrepreneurial outcomes. Therefore, 
it is plausible that individuals with non-profit experience will be trained to be social entrepreneurs who can lead their social enterprises to achieve both a social and a commercial mission effectively.

Finally, experience in the non-profit sector is more likely to legitimate founders as social entrepreneurs than experience in the for-profit-sector. According to organization theorists, legitimacy is important because an organization will be perceived as less desirable, improper, or inappropriate without gaining legitimacy (Suchman, 1995). Because lack of legitimacy could make it difficult for social entrepreneurs to gather supporters, resources, and endorsements from various stakeholders such as communities, governments, or donors, the importance of attaining legitimacy has been emphasized in the context of social entrepreneurship (Ruebottom, 2013). Previous studies proposed that the key to the legitimacy of social entrepreneurship is alignment with the non-profit sector (or social sector) (Pache \& Santos, 2013; Parkinson \& Howorth, 2008). In other words, founders with non-profit experience are insulated from the pressure of legitimacy acquisition. For example, according to discourse analysis with social entrepreneurs, Parkinson and Howorth (2008) argue that social entrepreneurs perceive themselves to be legitimated because of their social morality, rather than through traditional entrepreneurial activities. Conversely, a founder without non-profit experience may perceive deficient legitimacy. It may keep her/his social enterprises from achieving a high level of centrality. Pache and Santos (2013) show that "social sector" origin could provide a social enterprise with "institutional freedom” (Pache \& Santos, 2013, p.995), which could help a social enterprise to incorporate competing institutional logics. 
Therefore, I propose that there is a positive relationship between a social entrepreneur's prior non-profit work experience and centrality.

However, there may be a point above which an increase in a founder's non-profit experience does not add to her/his social enterprise's ability to achieve the centrality of competing logics. In other words, at higher levels of non-profit experience, added founder experience in the non-profit sector is likely to impede the strengthening of the centrality of competing logics. In fact, it may decline at high levels. I apply three perspectives to explain when (or why) a social entrepreneur's non-profit experience can weaken the centrality of competing logics based on the constraints of knowledge structure, prioritizing socialization, and identity conflict.

First, an excessive amount of non-profit experience may restrict a founder's knowledge structure to the non-profit sector exclusively. In general, previous studies posit that experience above a certain point results in restriction or decision-making rigidities (Kotha \& George, 2012; Sorensen \& Stuart, 2001). This is mainly because individuals as decision makers are rationally bounded and prefer to exploit their existing knowledge (March \& Simon, 1958). For example, from an investigation of the consumer digital imaging industry in the United States during 1991-2006, Benner and Tripsas (2012) demonstrate that prior experience shaped the firms' belief structure, showing that firms with similar backgrounds are likely to introduce a similar feature for a digital camera. Similarly, in an analysis with 120 new entrants in air-transportation industry from 1995 to 2000, Fern, Cardinal, and O’Neil (2012) also show that the strategic choices of new entrants are strongly constrained by founders' past experience. They argue that "founders who overly relied on their historic industry experiences may replicate 
strategies of legacy firms" ( $\mathrm{p} 427)$. The extant research, therefore, implicitly indicates that a social entrepreneur who may be overly experienced in non-profit sectors may fail to incorporate social and commercial logics due to the possibility of simply replicating the structures, practices, or strategies of non-profit organizations.

Second, founders with an excessive amount of non-profit experience may not only hire employees with a background in social work, but also socialize them to prioritize social logic over commercial logic, which can decrease the degree of centrality of competing logics. Previous studies have documented the importance of the practices of socialization to maintain the hybridity of social enterprises (Battilana, et al, 2014; Battilana \& Dorado, 2010). For example, in the study of French Work Integration Social Enterprise, Battilana and her colleague (2014) argue that it is possible for socially imprinted founders to set up an organizational system for social wealth maximization, not economic profitability.

Third, founders who have largely spent their career within the non-profit sector may perceive their role more as "nonprofit workers" than "entrepreneurs." Role identity refers to a person's sense of self with regard to a specific role (Burke \& Tully, 1997). According to identity theory, expectations and meanings associated with the role, such as a doctor, teacher, parent and a worker will guide individuals' behavior. In addition, these social roles often are performed concomitantly (Stryker \& Burke, 2000). Specifically, individuals have multiple role identities such as worker and students (Markel \& Frone, 1998). For example, when someone is a worker and a student at the same time, he or she has multiple role identities. Multiple role identities, however, are not equally self-relevant and salient. If one of the role identities has more salience, it provides some individuals 
with more meaning, which invokes behaviors related to salient role identity (Stets \& Burke, 2000; McCall \& Simmons, 1978). Because salience is affected by the amount of commitment (Stryker \& Serpe, 1994), the idea of identity salience suggests that a long time spent in the non-profit sector can confer a stronger salience for a "nonprofit worker" identity than for an "entrepreneurial" identity, which helps social entrepreneurs with longer experience in the non-profit sector to enact supportive behaviors toward social logics, rather than commercial logics. There is similar evidence in academic entrepreneurship literature that indicates that tenured scientists who spent a long time being trained in academia are not likely to behave as pure entrepreneurs, despite their involvement to commercialization activities (Jain, George, \& Maltarich, 2009).

Consistent with the above reasoning, I hypothesize that a social entrepreneur's non-profit experience to exhibit a non-linear relationship with centrality of competing logics. The centrality of competing logics increases at a low-to-moderate level of a social entrepreneur's non-profit experience, but turns negative for social entrepreneurs with a moderate-to-high level of non-profit experience.

H4: There is a curvilinear relationship between a founder's level of nonprofit experience and the centrality of competing institutional logics. Specifically, low-to-moderate levels of non-profit experience are positively related to the centrality of competing institutional logics; whereas, moderate-to-high levels of non-profit experience will have a negative relationship with the centrality of competing institutional logics 


\section{The Moderating Role of a Social Entrepreneur's Attributes}

I focus on two attributes of social entrepreneurs, which are associated with evaluating issues, allocating resources, and perceiving value: (1) a social entrepreneur's ambivalent interpretation and (2) a social entrepreneur's career variety. I expect these two variables to moderate the curvilinear relationship between the non-profit experience of a social entrepreneur and the centrality of competing institutional logics. More specifically, I expect the relationship between the non-profit experience of a social entrepreneur and the centrality of competing institutional logics to be more pronounced when overall a social entrepreneur's ambivalent interpretation and his or her career variety is low than when it is high.

Social Entrepreneur's Ambivalent Interpretation. A social entrepreneur's ambivalent interpretation refers to his or her competing evaluations of strategic issues (Plambeck \& Weber, 2010). Strategic issues are environmental trends and events that could have a major, discontinuous impact on a firm (Ansoff, 1975: 24-25; Egelhoff, 1982). When such issues are evaluated simultaneously as having both a positive and negative impact, ambivalence occurs (Plambeck \& Weber, 2010). I expect that the curvilinear relationship between non-profit experience of a founder and the centrality of competing institutional logics will be less profound in social enterprises with an entrepreneur who evaluated strategic issues ambivalently. This is likely to be reasonable for several reasons.

First, a social entrepreneur's ambivalent interpretation of strategic issues could be considered as an organizational condition that might impact an unbiased resourceallocation decision. It implies that critical resources will be distributed less differently 
either to social activities or commercial activities if a social entrepreneur has a high level of ambivalent interpretation, even if a social entrepreneur lacks non-profit experience or spends too much time in the non-profit sector prior to starting a social enterprise. Both behavioral decision theory (BDT) and strategic issue diagnosis (SID) have assumed that strategic decisions are connected by cognition, emotion, and social behavior (Powell, Lovallo, \& Fox, 2011). These theories suggest that resource-allocation decisions are based on how a strategic issue is framed, either positively or negatively (e.g., Bateman \& Zeithaml, 1989; Bazerman \& Moore, 2008; Chattopadhyay, Glick, \& Huber, 2001; Dutton, 1997; Ginsberg \& Venkatraman, 1995; Kahneman, Slovic, \& Tversky, 1982). Extant research argues that positively evaluated issues are more likely to attract the organizational resources than negatively evaluated issues do (Bateman \& Zeithaml, 1989; Ginsberg \& Venkataramn, 1995). According to the current research, however, ambivalent individuals are less likely to evaluate issues, either as positive or negative. Rather, they try to develop an holistic view of the issues (Petty et al., 2007). Thus, organizations with highly ambivalent CEOs may allocate resources equally to either positively evaluated issues or negatively evaluated ones because their CEOs are more likely to evaluate simultaneously the strategic issues as positive and negative. Applying this argument to this study suggests that critical resources will be distributed less differently either to social activities or commercial activities if a social entrepreneur has highly ambivalent interpretation, even if a social entrepreneur lacks non-profit experience or spends too much time in the non-profit sector prior to starting a social enterprise.

Second, a social entrepreneur's ambivalent interpretation of strategic issues is associated with organizational ambidexterity (Plambeck \& Weber, 2010), defined as the 
capacity of an organization to achieve high levels of trade-off (Cao et al., 2009). A social entrepreneur's ambivalent interpretation can be related to a broad-minded focus on strategic positions, which was linked to a wider spectrum of issues (Plambeck \& Weber, 2010: 693-694). Those in which social entrepreneurs interpret issues most ambivalently improve their ability to have a wider spectrum of strategic issues. This wider spectrum of strategic issues generated by ambivalent social entrepreneurs can become essential for dealing with the obstruction of high degree of centrality of competing logics.

Third, a social entrepreneur's ambivalent interpretation was also associated with managerial perception, which is "important values lead to actions consistent with them" (Adams, Lincht, Sagiv, 2011: 1334; Sagiv et al., 2011; Verplanken and Holland, 2002). By evaluating both logics as valued, ambivalent social entrepreneurs are less likely to respond more to one of them, although there is pressure to do so due to their limited or higher range of non-profit experience.

Thus, it is logical to assume that positive benefits of low to moderate levels of the founder's non-profit experience on the centrality of competing logics may become less salient for social enterprises with a founder whose ability of ambivalent interpretation is high. At the same time, at a moderate-to-a-high level of founder non-profit experience, the negative of a direct relationship with the centrality of competing logics will weaken as a social entrepreneur's ambivalent interpretation increases. Under this condition, as the non-profit experience of a founder increases, any diminishing returns to the centrality of competing logics may be mitigated through unbiased-resource allocation, organizational ambidexterity, and unbiased value perception. In this light, the curvilinear effects of the non-profit experience of a social entrepreneur on the centrality of competing institutional 
logics will be less likely to be profound if social entrepreneurs evaluated issues more ambivalently.

H5: A social entrepreneur's ambivalent interpretation will moderate the curvilinear relationship between his or her non-profit experience and the centrality of competing logics; specifically, the curvilinear relationship will be less pronounced (i.e., exhibit lesser curvature) among social enterprises with their founder exhibiting a higher level of ambivalent interpretation than social enterprises with their founder exhibiting a lower level of ambivalent interpretation..

A Social Entrepreneur's Career Variety. A social entrepreneur's career variety is similar to $C E O$ career variety, which refers to "the array of distinct professional and institutional experiences an executive has had prior to becoming a CEO" (Crossland, Zyung, Hiller, \& Hambrick, 2013). Social-entrepreneur-career variety may also moderate the curvilinear relationship between the non-profit experience of a social entrepreneur and the centrality of competing institutional logics. Similar to the moderating role of a social entrepreneur's ambivalent interpretation, I also expect that an organization with a social entrepreneur who is low in career variety will magnify the impact of non-profit experience of the social entrepreneur on the centrality of competing institutional logics. The reasons are threefold.

First, one of the features of CEO career variety is an awareness of a wide array of paradigms and exemplars (Crossland et al., 2013). High-variety CEOs seem to possess cognitive breadth, defined as an awareness of multiple perspectives, which makes it possible to view problems from different perspectives. It ultimately helps them to 
generate creative solutions (Crossland et al., 2013). Based on this notion, broad knowledge about multiple perspectives implies that a high-variety social entrepreneur might understand a broad range of knowledge about the needs and demands, the so-called "utility function" of customers, funders, and other important resource providers than lowvariety social entrepreneur (Harrison et al., 2010). Harrison and his colleague (2010) argue that if a firm can acquire nuanced information about a stakeholder's utility function, a firm can fine-tune strategies to deal with the demands of stakeholders, increase capacity for unexpected events, and generate a high level of innovation. Building on this notion, I expect that at low-to-moderate levels of a social entrepreneur's non-profit experience, a positive relationship with the centrality of competing logics will strengthen as a social entrepreneur's various career-spanning activities increase. Under these conditions, social entrepreneurs with a high level of career variety benefit from a high level of cognitive breadth through their various career-spanning activities. These benefits may help social entrepreneurs understand what consumers want, how to approach the market, or how to gain legitimacy effectively, despite having relatively limited non-profit experience. It may lead to a higher level of centrality for the competing logics. Conversely, these benefits help to mitigate the negative relationship with centrality at a moderate-to-high level of non-profit of social entrepreneurs as their career variety increases because open mindedness from career variety may also help social entrepreneurs overcome the constrained knowledge structure, restricted hiring processes, and social mission oriented identity generated from excessive amount of time spent in non-profit sector.

Second, CEO-career variety is also associated with a CEOs' social capital, which consists of available resources derived from an actor's social relations inside as well as 
outside an organization (Adler \& Kwon, 2002). Social capital can be generated by both past and current professional experiences (Hillman \& Dalziel, 2003). The benefit of a manager's (or CEO's) social capital has been reported in the management literature (Geletkanycz, Boyd, Finkelstein, 2001; Sundaramurthy, Pukthuanthong, \& Kor, 2013). For example, social capital shapes the conditions that convey knowledge and resources into an organization by broadly connecting to both inside and outside groups (Cao, Maruping, \& Takeuchi, 2006). A high level of CEO social capital provides the capability to understand diverse opinions (Kogut \& Zander, 1992; Nahapiet \& Ghoshal, 1998). High internal social capital also allows CEOs to control the allocation of knowledge and resources within an organization (Cao et al., 2006; Cao, Simsek, \& Jansen, 2012).

Third, a CEO's accumulated career experience can be also associated with increases in human capital. Human capital refers to acquired knowledge and skills via investments in schooling, on-the-job training, and work-related experience (Becker, 1975; Unger, Rauch, Frese, \& Rosenbush, 2011). Pertinent research has generally supported a positive relationship between entrepreneurs' human capital and effective and efficient management of their ventures (Chandler \& Jansen, 1992; Cooper, Gimeno, \& Woo, 1994; Gimeno, Folta, \& Cooper, 1997). This is mainly because accumulated experience through various types of careers may provide a $\mathrm{CEO}$ with an effective management skill sets to different value environments. For example, Carpenter, Sanders, and Gregersen (2001) show that multinational companies with CEOs having international experience outperform than those with CEOs without such experience. Carpenter et al. (2001) interpret this finding as being due to the positive effects of experience on dealing with international complexity. 
Even if social entrepreneurs are not familiar with the social sector environment due to a lack of non-profit experience, social entrepreneurs having various career paths can easily achieve a high level of centrality through her/his accumulated social capital and human capital. Conversely, at moderate to high levels of founder's non-profit experience, the negative relationship with centrality will be attenuated if social entrepreneurs have high level of career variety because wider range of social capital, as well as cultivates greater human capital through their various career paths may enable them to minimized the drawbacks such as the knowledge constraints, preference for social workers, and fixed identity due to the excessive amount of non-profit experience. Collectively, these arguments suggest that I expect a curvilinear relationship between the non-profit experience of a social entrepreneur and the centrality of competing logics, which will be weaker for social entrepreneurs with a high degree of career variety. The above arguments lead to the following hypothesis:

H6: A social entrepreneur's career variety will moderate the curvilinear relationship between his or her non-profit experience and the centrality of competing logics; specifically, the curvilinear relationship will be less pronounced (i.e., exhibit less curvature) among social enterprises with their founder having a higher career variety than social enterprises with their founder having lower career variety. 


\section{CHAPTER 4: RESEARCH DESIGN AND METHODS}

\section{Empirical Setting and Data}

The sampling frame is Korean social enterprises. Korean social enterprises provide a particularly appropriate context to study how a social enterprise's centrality of competing institutional logics may be influenced by heterogeneity in each stakeholder group. There are several reasons why testing hypotheses on a sample of Korean social enterprises is beneficial.

First and foremost, this sampling frame overcomes the problem of identifying social enterprises. There is a general absence of accepted definition or identification of social enterprises in the field of social entrepreneurship (Smallbone \& Lyon, 2005). Previous researchers have heavily relied on self-identified social enterprises (Miller \& Wesley, 2010). This lack of identification also leads to challenges of conducting empirical studies with a large sample (Short, Moss, \& Lumpkin, 2009). In order to overcome the difficulty of identification, South Korea has used an approval system for social enterprises using solid criteria. Organizations that fail to satisfy the criteria have not been allowed to use the term "social enterprise" (Bidet \& Eum, 2011; Park \& Wilding, 2012), which was mandated under Act 19 of Social Enterprise Promotion Act (SEPA) since 2007. The Act legally defines a certified social enterprise as a "an organization which is engaged in business activities, such as producing and selling goods and services, while pursuing a social purpose of enhancing the quality of local residents' life by means 
of providing social services and creating jobs for the disadvantaged" (article 2; Bidet \& Eum, 2011, p.77). Specifically, "Social Enterprise Support Committee is responsible for deciding whether the organization is certified or not as a social enterprise (article 4, Bidet \& Eum, 2011, p.78)." "Organizations should provide the proof of the relationship between their activities and a social goal (Bidet \& Eum, 2011, p.78)." Certificated social enterprises should re-invest their profits in social causes (article 8).

Second, South Korea is a society in which social and commercial logics are more fiercely separated than other countries. For example, styles of business management in South Korea have been influenced by U.S. firms (Dyer and Chu, 2003); whereas, its welfare system follows the 'Nordic' or 'social-democratic' welfare regime of European countries (Bidet, 2012; Gough, 2001; Kuhnle, 2003). Thus, South Korean social enterprises may demonstrate a clearer influence than in most other setting to examine social and commercial logics inside organizations.

Third, when social entrepreneurship was initiated in South Korea, the best features of the concepts from both Europe and USA were studied in order to implement the most ideal social enterprises (Bidet \& Eum, 2011). South Korean policies were enacted based on 1991 UK and Italian case law. Thus, as an emerging market, South Korea expands our understanding social entrepreneurship in a different, international context.

Consequently, the majority of data for this dissertation was collected from a survey of Korean social enterprises using Korea Social Enterprise Promotion Agency (KSEPA)'s directory, which has tracked 1,012 certified social enterprises. Following the total design method suggested by Dilman (1978), I conducted 11 preliminary interviews 
with social entrepreneurs between April and July 2013. I purposely selected the organizations and targets to understand the phenomena of responsiveness to competing institutional logics as well as refine the questionnaire's items in depth. Appendix C provides a brief description of the 11 social enterprises that I interviewed. After considering the feedback I received and reflecting on many concerns, I prepared the final questionnaire. I created the questionnaire in English first, later translating it into Korean, consistent with the suggestion of Brislin's (1970) translation-back-translation.

I sent an email containing the final questionnaires to 1,002 eligible social enterprises listed by the Korea Social Enterprise Promotion Agency (KSEPA) over four months from April to July of 2014 .The email explained the goal of this study, the voluntary nature of participation, its confidentiality policy, and a link of the survey's Web site. In line with current studies, the letter promised that an executive summary would be given as incentive to each participating social enterprise (Heavey \& Simsek, in press). After sending an invitation to participate in the web-based survey, I emailed three reminders and made several phone calls according to the recommendations (Kriauciunas, Parmigiani, \& Rivera-Santos, 2011). A total of 281 responses from CEOs were returned, representing an initial response rate of $28.04 \%$, which compares favorably with other studies surveying top managers (Heavey \& Simsek, in press; Schilke \& Cook, 2013).

In order to avoid common method bias and social desirability bias--defined as the tendency that respondents are likely to report overly "good behavior" and rarely "bad behavior"--prior research has suggested using third-party observers as informants instead of using CEOs as key informants. Following this suggestion, I contacted the 281 social enterprises again and asked middle managers to assess the extent to which topics were 
attended to in high-level discussions. This approach is also consistent with the suggestion for using multiple survey informants (Kumar, Stern, \& Anderson, 1993). In total, 203 social enterprises have completed two sets of surveys. I deleted 13 responding firms due to missing data, resulting in a total of 190 usable responses (for a total usable response rate of $18.96 \%)$.

Nonresponse bias. To assess sample representativeness, I tested for a potential non-response bias in three different ways. First, as seen in Table 1, I contacted 30 nonrespondents randomly by the telephone and asked them to provide demographic information about their company (c.f. Mentzer, Flint \& Hult, 2001). Then, I compared group mean differences between respondents and 30 non-respondents on those background characteristics such as firm age, firm size, number of board of directors, and debt ratio 2012. An analysis of variance (ANOVA) of group means revealed no significant differences (see the Table $1 ; \mathrm{Fs}<0.10, \mathrm{p}>0.10$ ).

Table 1. Test of Non-Response Bias: Comparison with Non-Respondents

\begin{tabular}{lccc}
\hline \multicolumn{1}{c}{ Variable } & df & F & p-value \\
\hline Firm Age $(\log )$ & 1,253 & 0.002 & 0.962 \\
Number of employees $(\log )$ & 1,253 & 0.051 & 0.822 \\
Number of BOD & 1,253 & 0.086 & 0.770 \\
Debt ratio 2012 & 1,253 & 0.004 & 0.949 \\
\hline
\end{tabular}

Second, following the recommendations (Armstrong \& Overton, 1977; Dooley \& Lindner, 2003), I compared early respondents with late respondents on key theoretical constructs (Top management's attention to social and commercial issues, proportion of ethical investors/reciprocally motivated customers/cross-sector workers, founder's nonprofit experience, and ambivalent interpretation) as well as several control variables such 
as the natural log of firm age, firm performance, future expectation of performance, debt ratio, founder's age, and gender. On average, $38.5 \%$ of sample responded to the early mailing, while $61.5 \%$ of my sample was late responders.

Table 2. Test of Non-Response Bias: Early vs. Late

\begin{tabular}{lcccc}
\hline \multirow{2}{*}{\multicolumn{1}{c}{ Variable }} & \multicolumn{2}{c}{ Early responders vs. Late responders } \\
\cline { 2 - 5 } & $\begin{array}{c}\text { Mean for } \\
\text { early } \\
\text { responders }\end{array}$ & $\begin{array}{c}\text { Mean for } \\
\text { late } \\
\text { responders }\end{array}$ & t-value & $\begin{array}{c}\text { p-value } \\
\text { (two-tail) }\end{array}$ \\
\hline TMT's attention to social issue & 5.279 & 5.227 & 0.383 & 0.702 \\
TMT's attention to financial issue & 5.482 & 5.394 & 0.625 & 0.533 \\
Firm age (log) & 1.633 & 1.599 & 0.437 & 0.662 \\
Financial performance & 4.345 & 4.326 & 0.137 & 0.891 \\
Attainment Discrepancy (dummy) & 0.163 & 0.113 & 1.065 & 0.288 \\
Debt ratio 2012 & 0.227 & -0.015 & 0.266 & 0.790 \\
Diversity of BOD & 0.273 & 0.325 & -1.429 & 0.154 \\
Duality (dummy) & 0.796 & 0.786 & 0.170 & 0.865 \\
Proportion of ethical investors & 0.589 & 0.498 & 1.619 & 0.107 \\
Proportion of reciprocally & 0.103 & 0.120 & -0.570 & 0.570 \\
motivated customers & 0.263 & 0.184 & 1.535 & 0.127 \\
Proportion of cross-sector workers & 6.279 & 5.924 & 0.452 & 0.652 \\
Founder's non-profit experience & 7.226 & 6.405 & 0.915 & 0.362 \\
Founder's for-profit experience & 1.188 & 1.533 & -1.245 & 0.214 \\
Ambivalent Interpretation & 1.727 & 1.542 & 0.625 & 0.533 \\
Career Variety & 3.913 & 3.897 & 0.680 & 0.497 \\
Founder's age (log) & 3.980 & 3.880 & 0.612 & 0.541 \\
Founder's education & 1.350 & 1.290 & 1.024 & 0.307 \\
Founder's gender & & & & \\
\hline
\end{tabular}

As shown in Table 2, the results of the $t$-tests indicated no significant differences between early and late respondents $(\mathrm{p}>0.10)$. Finally, I compared the firms in the samples to 1,002 firms in the initial mailing list with respect to the social enterprises' categories (5 categories). A Komogorov - Smirnov (KS) two-sample test identified no 
significant differences between two groups. $\left(\chi^{2}=8.114, p=.09>0.05\right)$. With this range of three tests, nonresponse bias in this study was not a problem.

\section{Study One: Measures, Validation, and Statistical Procedures}

\section{Dependent Variable}

Centrality of Competing Logics. The primary dependent variable in this study is the centrality of competing institutional logics. Following the discussion in Chapter 1, I regarded a social welfare logic and a commercial logic as top management' attention to social welfare issue and commercial issue, respectively. Adopting the process by Weaver, Trevino, and Cochran (1999) and Muller and Kolk (2009), I listed a broad range of topics from which top managers may have discussed at the time of high-level discussions because topics in high-level discussions are considered as important issues (Weaver, Trevino \& Cochran, 1999). Then, I asked to rate "the extent to which various subjects were a topic of conversation for their firm's top management team" (Weaver, Trevino \& Cochran, 1999: 549). To be specific, middle managers as respondents assessed how often top managers discussed: (1) seeking the good of society, (2) the company's role in society, (3) improving social conditions, (4) efforts for beneficiaries, (5) financial performance, (6) stockholders and investors, (7) strategy and planning, and (8) productivity and efficiency. Middle managers were asked to complete a randomly ordered eight-item list of questions on a 7-point Likert-style scale (1=never, 7=very frequently) top management attention scored such that higher numbers will reflect a greater attention to social welfare issues and financial issues. First four indicators pertained to top management's attention to social issues and second four items pertained to top management's attention to commercial issues. 
To evaluate the reliability and validity, I calculated Cronbach's alpha for each four items, which yielded an acceptable single scale with Cronbach alpha $=.90$ for attention to social issues and .75 for commercial issues. ${ }^{1}$ Then, I used confirmatory factor analysis (CFA) to examine the validity of measures. I specified top management's attention to social and financial issues as first-order factors with each four indicators, respectively. Although the result showed acceptable model fit $\left(x^{2}(18)=37.58 ; x^{2} /\right.$ $d f=2.08 ; \mathrm{CFI}=0.976 ; \mathrm{TLI}=0.962 ;$ root mean square error of approximation (RMSEA) $=0.075)$, the standardized factor loading of one indicator (6. stockholders and investors, $\mathrm{SFL}=0.35$ ) was below the recommended threshold of .05 (Hair et al., 2009). Thus, I dropped the sixth item from the measures and re-calculated Cronbach's alpha for top management's attention to commercial issues. Afterward, I performed CFA for two firstorder factors again. Overall, Cronbach's alpha was increased from 0.75 with four items to 0.83 with three items for top management's attention to commercial issues. The modified result of CFA also confirmed better fit $\left(x^{2}(12)=26.46 ; x^{2} / d f=2.20\right.$; CFI $=0.982$; TLI $=0.968 ;$ root mean square error of approximation $($ RMSEA $)=0.078)$. All factor loadings were also higher than the cutoff point (range from 0.75 to 0.90$)$ and significant $(p<.001)$. According to Shook, Ketchen, Hult, and Kacmar (2004), discriminant validity is satisfactory if the average variance extracted (AVE) exceeds the cutoff of 0.5. AVE values of 0.67 for top management's attention to social issues, and 0.62 for commercial issues were obtained in this study, which indicated acceptable discriminant validity. Consequently, the construct of top management's attention to social issues was computed as the average of the four items; whereas, the construct of top management's attention to

\footnotetext{
${ }^{1}$ Cronbach's alpha higher than .07 is acceptable (Nunnally \& Bernstein, 1994)
} 
commercial issues was a mean of three items. Individual item scales, standardized factor loadings, Cronbach's alpha, and AVE are listed in Table 3.

Table 3. Validity Assessment for Constructs of Top management's attention to competing issues

\begin{tabular}{|c|c|c|c|c|}
\hline Constructs & Items & Mean & SD & SFL $^{\mathbf{c}}$ \\
\hline \multirow{4}{*}{$\begin{array}{l}\text { Top management's } \\
\text { attention to social } \\
\text { issues }^{\mathrm{a}}\end{array}$} & Seeking the good of society & 5.14 & 1.35 & $0.75^{* * *}$ \\
\hline & The company's role in society & 5.36 & 1.22 & $0.86^{* * *}$ \\
\hline & Improving social conditions & 5.12 & 1.20 & $0.90^{* * * *}$ \\
\hline & Efforts for beneficiaries & 5.40 & 1.17 & $0.77^{* * *}$ \\
\hline \multirow{3}{*}{$\begin{array}{l}\text { Top management's } \\
\text { attention to commercial } \\
\text { issues }{ }^{\mathrm{b}}\end{array}$} & Financial performance & 5.21 & 1.29 & $0.72^{* * *}$ \\
\hline & Strategy and planning & 5.57 & 1.18 & $0.86^{* * *}$ \\
\hline & Productivity and efficiency & 5.66 & 1.23 & $0.78^{* * *}$ \\
\hline
\end{tabular}

To capture the centrality of competing logics, I used Janis-Fadner (JF) coefficient of imbalance, which has been widely used to calculate media tenor (Deephouse, 1996; Pollock \& Rindova, 2003) and work-family balance (Greenhaus, Collins, \& Shaw, 2003). This coefficient allows us to measure the relative proportion of top management's attention to social issues and commercial issues. The formula is:

$$
\text { Coefficient }=\frac{\left(S^{2}-S C\right)}{T^{2}} \text { if } S>C ; 0 \text { if } F=S ; \frac{\left(S C-C^{2}\right)}{T^{2}} \text { if } C>S,
$$

where $\mathrm{S}$ represents top management's attention to social issues, $\mathrm{C}$ is the attention to commercial issues, and $\mathrm{T}$ is the total attention. The range of this variable is -1 to 1 , where 1 equals "attention to all social issues" and -1 equals "attention to all commercial issues." To interpret them, a score of zero represents equal weighting for top management's attention to both competing issues, which further indicates a high level for the centrality of competing institutional logics. On the other hand, positive scores represent a social welfare logic focus and negative scores represent a commercial logic 
focus. The greater the absolute number of a score suggests unequal weighting for top management's attention to both competing issues, which corresponds to a low level of the centrality for competing institutional logics. I converted the negative scores to absolute value. In order to facilitate interpretation, I also reversed absolute number of the score by multiplying constant -100 so that a greater value indicates higher level of the centrality of competing logics. Maximum is 0.00 , minimum is -35.35

\section{Independent Variables}

All independent variables are used with one year lagged variables.

Proportion of Ethical investors. Ethical investors are largely understood that their investments are the ones without an expectation of financial return (Höchstädter \& Scheck, 2014, Moore et al., 2012). Adopting the categories developed by Spiess-Knafl and Achleitner (2012), I identified six categories: (1) an investment from inside investors without an expectation of financial return, (2) an investment from inside investors with a reduced financial return expectation, (3) an investment from inside investors with a market rate financial return expectation, (4) an investment from outside investors without a financial return expectation, (5) an investment from outside investors with a reduced financial return expectation, (6) an investment from outside investors with a market rate financial return expectation. I asked respondents to estimate the proportion of investments falling into a number of investment classifications. In this study, the proportion of ethical investors was calculated as the ratio of internal and external investments without financial expectations to the total investments in the social enterprises. The higher scores represent the greater proportion of ethical investors. 
Proportion of reciprocally motivated Customers. I captured four customer-group categories based on initial motivations for buying the products of social enterprises (Hibbert, Hogg, \& Quinn, 2005). I asked respondents to estimate the proportion of buyers falling into a number of classifications: (1) beneficiaries, (2) economic customers, (3) reciprocally motivated customers, and (4) pure altruistic customers. The proportion of reciprocally motivated customers was measured by the ratio of customers motivated by reciprocity to the total customers in the social enterprises. The higher scores represent the greater proportion of customers motivated by reciprocity.

Proportion of cross-sector workers. To construct the percentage of cross-sector workers, I classified employees into four different groups using their prior work experience: (1) social sector, (2) commercial sector, (3) both social and commercial sectors, and (4) non-experience. Then, I measured the proportion of cross-sector workers using the ratio of employees having work experience in both social and commercial sectors to the total employees in the social enterprises. The higher scores represent the greater proportion of cross-sector workers.

\section{Control Variables}

Because many other factors could systematically affect the pressure to respond more decidedly using either a social logic or a commercial logic, I include numerous variables in the analysis for the purpose of control.

Total attention to issues. According to previous research, no differences would be expected if there were little involvement with both competing issues (Greenhaus, et al., 2003). It means that the centrality of competing logics can be substantially influenced by the total amount of attentions to both social and commercial issues. Thus, total attentions 
to competing issues were incorporated in the control variables. This value was calculated by the sum of top management's attention to both social issues and commercial issues.

Legal status. For social enterprises, there are broadly two kinds of legal status, which are a nonprofit form such as an incorporated association, a trust, or a foundation, or a for-profit form such as a proprietorship, a partnership, or a corporation (Kistruck \& Beamish, 2010; Austin et al., 2006; Mair \& Marti, 2006; Young, 2001). To date, most social entrepreneurship literature has treated social entrepreneurial organizations as a homogenous group. However, legal status on either for-profit or nonprofit forms itself makes a difference to several activities. It is not only directly associated with tax, funding, or opportunities (Dees \& Anderson, 2003; Kistruck \& Beamish, 2010; Korosec \& Berman, 2006; Simms \& Robinson, 2009), but also related to the practices of the social enterprises. For example, although non-profit social enterprises such as incorporated associations can receive philanthropic support from outside (e.g. government or voluntaries) to subsidize their costs (Dees \& Anderson, 2003), for-profit social enterprises such as limited liability companies are not able to do so. On the other hand, if a social enterprise acquires a non-profit legal form, one can expect this social enterprise should limit its profits to be distributed to investors or owners, which is known as a nondistribution constraint (Hansmann, 1980). Thus, I controlled for legal status by using dummy code, which it is dummy coded " 1 " when a social enterprise has a for-profit legal status, and " 0 " if it has a non -profit legal status.

Prior performance. The extant literature has suggested that there is a positive relationship between a firm's performance and its investment in corporate social responsibility (CSR) (Waddock \& Graves, 1997). The behavioral theory of the firm 
(BTOF, Cyert \& March, 1963) argues that past performance can serve as a firm's aspiration level (Baum, Rowley, Shipilov, \& Chuang, 2005). According to past performance, we can also calculate attainment discrepancy, defined as a firm's relative performance compared to past performance (Aroa \& Dharwadkar, 2011). For example, if actual performance exceeds the aspired performance, shareholders become trust managers providing them with higher discretion to allocate resources. Trust management is also significantly associated with a higher level of corporate social responsibility (CSR) (Aroa \& Dharwadkar, 2011). It further implies that past performance and attainment discrepancy could impact the centrality of competing institutional logics. Consequently, I controlled for prior performance using eight items, a 7-point Likert scale that was validated and often used in the previous research (Stam \& Elfring, 2008; Wang \& Bansal, 2012). Respondents were asked to compare their social enterprises' performance with other similar social enterprises in each area on a scale ranging from 1, "your organization was much worse," to 7, "your organization was much better than similar organizations." The Cronbach's alpha was .94, which exhibits acceptable inter-item reliabilities. A confirmatory factor analysis (CFA) was also conducted to gauge the validity of the measures. The result showed acceptable model fit $\left(x^{2}(14)=25.35 ; x^{2} / d f=1.81 ; \mathrm{CFI}=\right.$ 0.992; TLI $=0.985$; root mean square error of approximation $($ RMSEA $)=0.063)$. For the convergent validity, I also obtained a high AVE $(\mathrm{AVE}=.65)$.

Attainment Discrepancy Attainment Discrepancy is the same as a deviation from prior performance. Tuggle, Sirmon, Reutzel and Bierman (2010) reported that there were significant deviations from performance based on a board's attention to monitoring a firm, which also impacted a firm's discretion to allocate resources. Thus, it was dummy coded 
"1" when the current performance was expected to be greater than past performance, and "0" if not.

Firm Age. According to life-cycle theory, organizations are similar to individuals. They are born, they grow, and they get old (Van de van \& Poole, 1995). It is well known that older firms are more likely to experience pressure that requires them to be more conscious of their social responsibility. Although older firms are less likely to depend on external resources (Daily et al., 2002), it is hard for them to avoid ignoring expectations about social involvement because of their reputation and history (Roberts, 1992). GodosDíez et al. (2011) show a positive relationship between the age of a firm and its social involvement.

Firm age is also related to knowledge. Older firms are more likely to have a greater stock of knowledge (Gittelman \& Kogut, 2003). If firms are knowledgeable, it is reasonable to expect that they will deal with complex demands. In addition, the relative importance of different stakeholders will vary in accordance with an organization's life cycle stage (Jawahar \& Mclaughlin, 2001). Therefore, I controlled for the age of firms by subtracting the date of founding from 2014, which is consistent with prior research (Julian \& Ofori-dankwa, 2013). Because of the normality concern, I log transformed the value.

Ratio of Debt. Debt is negatively related to the social involvement of a firm because it is a reflection of a low level of resource availability (Brammer and Millington, 2008). Navarro (1988) argued that a high level of debt compared to equity negatively affects corporate giving. This is because debt decreases the discretion of managers and limits their ability to locate resources. It also leads managers to make decisions that favor 
a focal firm (Barnett \& Salomon, 2012), not society. Prior research has shown a negative relationship between a high debt-equity ratio and corporate social responsibility (CSR) or corporate donation (Arora \& Dharwadkar, 2011; Brammer and Millington, 2008). I expect that a high degree of debt will induce an organization to focus much more on commercial logics, which decreases the centrality of their competing institutional logics. Hence, I controlled the ratio of debt, measured by the ratio of long-term debt to total assets, which was consistent with Barnett and Salomon (2012).

Industry. Industries have different benefits, pressures, and expectations about a firm's behavior (Hitt et al., 2004; Reuer, Tong, Tyler, \& Ariño, 2013). In particular, prior research suggested controlling for the industry effect on the socially related activities of a firm (Amato \& Amato, 2007; Ussem, 1988; Vidaver-Cohen \& Altman, 2000). For example, insurance and mining have different levels of public contact (Ussem, 1988). To control for the potential effects of industrial sectors on the centrality of competing institutional logics in social enterprises, I will borrow a classification of seven areas from a recent social entrepreneurship study (Lee \& Battilana, 2013). According to Lee \& Battilana (2013), the seven areas of social enterprises include: (1) the arts and culture, (2) civil and human rights, (3) economic development, (4) education, (5) the environment, (6) health/healthcare, and (7) public service. This classification is consistent with ones from the Korea Social Enterprise Promotion Agency (KSEPA). In this study, I included one more category "other."

Type. According to their activities, social enterprises have also been grouped into two broad categories: social service enterprises and work integration social enterprises (WISEs) (Defourny \& Nyssens, 2008). However, other types of social enterprises can be 
identified in the real world. For example, Green Works, started in 2000, recycles wasted furniture. Then, schools, small businesses, and other charities buy the recycled or repaired furniture from Green Works. Green Works also hires people who are not competitive in the market. Reflecting this reality, KSEPA classified five different types of social enterprises: (1) social service, (2) work integration social enterprises (WISEs), (3) the mixture of social service and WISEs, (4) community-based, and (5) other.

Diversity of Board of Directors. Board members affect a firm's strategy (Hill \& Snell, 1988; Judge \& Zeithaml, 1992).This is because of their monitoring and evaluating the performance of the CEO (Vance, 1983). Traditionally, they were understood as shareholder agents (Jensen \& Meckling, 1976). Board members who have relevant experience can also provide useful advice to a CEO (Kroll, Walters, \& Wright, 2008). Thus, it has been argued that strategic actions can also be influenced by the experience of board members. For example, Golden and Zajac (2001) report there was a positive relationship between the proportion of board members' business occupations and the levels of strategic change. In line with prior research, I controlled for diversity of board members using their prior experience. For computation, I used the Blau index (1977). The formula is $1-\sum_{i=1}^{n} P_{i}^{2}$, where $\mathrm{P}$ is the proportion of board of directors with a past experience category $\mathrm{i}, \mathrm{N}$ is the total number of experience categories. In this study, I identified four categories of past experience: (1) the social sector, (2) the commercial sector, (3) a combination of both the social and the commercial sectors, and (4) nonexperience.

CEO Duality. If a CEO is the chairman of the board of directors at the same time, this is referred to as CEO duality (Baliga, Moyer, \& Rao, 1996). This additional CEO 
power lessens the level of monitoring by board directors (Tuggle, Sirmon, Reutzel, \& Bierman, 2010). If there is CEO duality in a social enterprise, the response to either a social or a commercial logic will be influenced by CEO preference. In this study, I controlled for CEO duality using a dummy variable, coded as " 1 " if CEO were the chairperson of the board, or " 0 " otherwise.

All measures in this dissertation are summarized in Appendix A.

\section{Statistical Approach}

I used ordinary Least Squares (OLS) regression to test hypotheses 1, 2, and 3. In order to test the effects of the proposed variables on centrality of competing logics, I ran five regression models adopting a hierarchical regression approach where I included independent variables in different stages. Before running the hierarchical regression models, assumptions were tested by examining normal probability plots of residual and scatter spots of residuals versus predicted residuals. No violations of normality, linearity, or homoscedasticity of residuals were detected. In addition, there was no evidence of outliers. To check for multicollinearity, I used the variation inflation factor (VIF). All VIFs were below 2.0, with the exception of the maximum VIF of 3.02. Therefore, multicollinearity was not an issue because all VIF's fell below 10 (Belsey, Kuh, \& Welsch, 1980; Kutner, Nachtsheim, \& Neter, 2004). 


\section{Study Two: Measures, Validation, and Statistical Procedures \\ Dependent Variable}

In study two, the dependent variable was the same as for study one: the centrality of competing logics.

\section{Independent Variable}

Founder's non-profit experience. Following the previous research (Astebro \& Thompson, 2011; Kim \& Logest, 2014), founder's non-profit experience can be measured by the number of years the social entrepreneurs reported having worked in the non-profit sector prior to starting the current social enterprise. Respondents were asked to answer the question: "how long have you had experience in non-profit sectors prior to your current social enterprise." Average years of respondents are 6.79 years.

\section{Moderator Variables}

Ambivalent interpretation. In order to operationalize ambivalence, I asked social entrepreneurs to indicate their positive or negative evaluation of a recent trend through the use of a designed vignette. The case described the current direction of government policy toward social entrepreneurship, from direct financial support to indirect marketoriented policy. I measured these trends using two items, a 7-point Likert scale each (1= strongly disagree, $7=$ strongly agree; see Appendix B for more detail). This approach is consistent with prior research on the evaluation of strategic issues (Plambeck \& Weber, 2010; Thomas \& McDaniel, 1990). Especially, usage of two sets of cases is consistent with the prior research of Thomas and McDaniel (1990) to enhance the generalizability. 
The Cronbach's alpha was 0.78 for the positive evaluation and 0.93 for the negative evaluation.

The vignette in Appendix B not only contains salient and complex recent trends that impact social enterprises, but it also provides the conditions for ambivalent evaluations. For example, the case of the current shift of policy from direct financial support to indirect market-based methods has both positive and negative aspects for social enterprises. I expect that market-based policy, such as an increase in the number of sales channels, will provide social enterprises with an opportunity to scale-up; however, social enterprises will be confronted with market-based competition because of the reduction in subsidies provided by the government, which prioritizes a commercial logic over a social-welfare logic. Table 4 lists the factor loading and Cronbach's alpha.

Table 4. Validity Assessment for Constructs of Ambivalent Interpretation

\begin{tabular}{|c|c|c|c|c|}
\hline Constructs & Items & Mean & SD & $\mathbf{S F L}^{\mathrm{c}}$ \\
\hline \multirow{3}{*}{$\begin{array}{l}\text { Ambivalent } \\
\text { Interpretation: } \\
\text { Positive Interpretation }^{\text {a }}\end{array}$} & Our company will benefit & 4.93 & 1.63 & $0.98^{* * *}$ \\
\hline & $\begin{array}{l}\text { from the current trend } \\
\text { described above. }\end{array}$ & & & \\
\hline & $\begin{array}{l}\text { The current trend described } \\
\text { above comprises a potential } \\
\text { gain for our company. }\end{array}$ & 4.68 & 1.67 & $0.65^{* * *}$ \\
\hline \multirow{3}{*}{$\begin{array}{l}\text { Ambivalent } \\
\text { Interpretation: } \\
\text { Negative Interpretation }^{\mathrm{b}}\end{array}$} & The current trend described & 2.93 & 1.54 & $0.94^{* * *}$ \\
\hline & $\begin{array}{l}\text { above is something negative } \\
\text { for our comnany. }\end{array}$ & & & \\
\hline & $\begin{array}{l}\text { There is a high probability of } \\
\text { losing a great deal because of } \\
\text { the current trend described } \\
\text { above }\end{array}$ & 3.01 & 1.57 & $0.93^{* * *}$ \\
\hline
\end{tabular}

Then, I computed ambivalent evaluation using a similarity-intensity model (SIM), which was employed by Thompson, Zanna, and Griffin (1995). I developed the SIM 
using designed hypothetical conditions, arguing that ambivalence is increased when the similarity between positive and negative is increased as well as when there is greater intensity for both positive and negative outcomes (Priester \& Petty, 1996). The formula follows: $A=(D+C) / 2-(D-C)$, where $\mathrm{D}$ is the dominant reaction and $\mathrm{C}$ is the conflicting reaction. For example, if a respondent's evaluation of a recent trend receives a " 6 " for the rating of "positive" and a " 4 " for the rating of "negative", then $\mathrm{D}=6$ and $\mathrm{C}=4$. Ambivalence can be calculated by $(6+4) / 2-(6-4)$, which equals 3. Although there are "4" for "positive" and "6" for "negative," D, C, and ambivalence score are identical to the former case. On the other hand, if both positive and negative evaluations are "7", the ambivalence score becomes "7." The higher the overall ambivalence score, the greater is the presence of both positive and negative evaluations at the same time (Plambeck \& Weber, 2010; Thompson et al., 1995).

A social entrepreneur's career variety. Adopted by Crossland et al. (2013) and Lee and Battilana (2013), I measured a social entrepreneur's career variety using seven items: (1) the number of industries, (2) the number of organizations, (3) the number of functions that an entrepreneur had worked prior to becoming a social entrepreneur of the focal firm, (4) age, (5) total years of career experience, and (6) education level. Following prior research (Crossland et al., 2013), I conducted an exploratory factor analysis (EFA) to assess convergent and discriminant validity as shown in Table 5 . The results in Table 5 are consistent with the previous study. Based on the results of EFA, I calculated career variety by summing the factors. 
Table 5. Social Entrepreneur's Career Variety: Exploratory Factor Analysis

\begin{tabular}{lccc}
\hline \multicolumn{1}{c}{ Variable } & Factor 1 & Factor 2 & Factor 3 \\
\hline Number of industries & $\mathbf{. 8 3 2}$ & .002 & .099 \\
Number of organizations & $\mathbf{. 8 1 2}$ & .146 & .083 \\
Number of functional areas & $\mathbf{. 8 1 1}$ & -.073 & -.173 \\
Age & -.190 & .865 & -.181 \\
Career experience & .338 & .751 & .261 \\
Education level & -.017 & -.002 & .969 \\
\hline
\end{tabular}

Therefore, the final measure of a social entrepreneur's career variety was computed by the sum of the number of industries, the number of organizations, and the number of functional areas, divided by the total years of career experience of a social entrepreneur. The average of the value was 1.66 , ranging from 0.15 to 15 . The Cronbach's alpha was .76.

\section{Control Variables}

All control variables in study one were re-used in the study two. In addition, there are several additional control variables at the founder level.

Founder Age Founder's age can impact the centrality of competing logics in social enterprises. This is mainly because that it is correlated with the decision of strategic choice in a firm. Extant research has documented the role of a CEO's age on a strategic decision (Fondas \& Wiersema, 1997; Wiersema and Bantel, 1992). Age can have positive or negative impact on the organizational decisions about the use of institutional logics based on their preference toward risk or the pursuit of opportunities. Although age is associated with experience and expertise, which leads an individual to exploit an opportunity, at the same time, the negative relationship between an owner's age and an opportunity has also been reported (Gielnik, Zacher, \& Frese, 2012; Zacher \& Frese, 2009). According to Gielnik et al. (2012), an individuals' willingness to focus on 
opportunities will decrease as the time left in one's life diminishes. Therefore, I

controlled for founder age by measuring years. Then, I log transformed it.

Founder's gender. Much anecdotal evidence suggests that there is also a positive relationship between women and generosity (Mesch, 2009). Despite conditional effects, women are likely to donate more than men (Mesch, Rooney, Steinberg, \& Denton, 2006; Rooney, Mesch, Chin, \& Steinberg, 2005) and be volunteers more than men (Einolf, 2009). At the organizational level, most leaders who are in-charge of philanthropic activities are women (Conry, 1998). I dummy coded gender as "1" if a founder was male, and " 0 " if not.

Founder's education level. Education level may be associated with human capital, defined here as skills and knowledge from schooling, training, or experience (Becker, 1964), which possibly impact the centrality of competing logics. A founder's level of education was measured by $1=$ high school, $2=$ bachelor's degree, $3=$ master's degree, and $4=$ doctoral degree.

Prior for-profit experience. Following a previous study (Lee \& Battilana, 2013), I computed prior for-profit experience using the total years of work experience in a commercial sector prior to starting the current social enterprise.

\section{Statistical Approach}

In order to test the possible curvilinear relationship between a founder's nonprofit experience and the centrality of competing logics as well as the proposed moderating effects of a social entrepreneur's ambivalent interpretation and her/his career variety, which are $\mathrm{H} 4, \mathrm{H} 5$, and $\mathrm{H} 6$, respectively, I used moderated hierarchical regression analysis. In the analysis, I examined the effects of the proposed variables on the centrality 
of competing logics. Not only has hierarchical regression been widely used to access nonlinearity (Cohen et al., 2002), it has been the preferred statistical tool to identify moderating effects (Aguinis, 1995). In particular, management scholars have used moderated hierarchical regressions to detect curvilinear moderation (Baer et al., 2010, Lechner et al., 2010). I mean centered the variables before I squared the independent variable, founder's non-profit experience, and created the interaction terms in order to minimize the multicollinearity problems (Aiken \& West, 1991; Dawson \& Richter, 2006). All VIF's were below 3.0 (maximum VIF was 2.92 in this study). Therefore, multicollinearity was not an issue because all VIFs fell below 10 (Belsey, Kuh, \& Welsch, 1980; Kutner, Nachtsheim, \& Neter, 2004). 


\section{CHAPTER 5: ANALYSIS AND RESULTS}

\section{Study One Results}

The following chapter summarizes what I have learned through the analyses. Table 6 contains the means, standard deviations, and correlations for all variables. Table 7 reports the results of five regression models explaining the centrality of competing logics, which was operationalized as the dependent variable: $F(19,171)=2.179$, $\mathrm{p}=.005<0.01$ in Model 1, $\mathrm{F}(20,170)=2.394, \mathrm{p}=.001<0.01$ in Model $2, \mathrm{~F}(20,170)=2.188$, $\mathrm{p}=.004<0.01$ in Model 3, $\mathrm{F}(20,170)=2.347, \mathrm{p}=.002<0.01$ in Model 4, $\mathrm{F}(22,168)=2.597$, $\mathrm{p}=.000<0.001$ in Model 5, respectively.

Model 1 contains only the control variables. $\mathrm{R}^{2}$ for the Model 1 is .195 , which means $19.5 \%$ of the variance in the centrality of competing logics is predicted by the control variables. The $\mathrm{R}^{2}$ for the Model 2 is .220 , which means $22.0 \%$ of the variance in the centrality of competing logics was predicted by the ratios of ethical investors to total investors. The inclusion of the percentage of ethical investors significantly improves the amount of variance explained by the model from the previous stage $\left(\Delta R^{2}=.025, p<.05\right)$. The results from Model 2 in Table 7 show that the coefficient of the proportion of ethical investors on the centrality of competing logics is positive and statistically significant ( $\beta$ $=.165, \mathrm{p}=.021<.05)$. It indicates strong support for Hypothesis 1 , which proposed that a greater portion of ethical investors would be positively associated with the centrality of competing logics. 
To test hypothesis 2 with regard to the effect of the characteristics of customers on the centrality of competing logics, Model 3 included the proportion of customers motivated by reciprocity. Although Model fit is statistically significant $(F(20,170)=2.188$, $\mathrm{p}=.004<0.01$ ), Model 3 doesn't represent a significant improvement over and above Model $1\left(\Delta \mathrm{R}^{2}=.010, \mathrm{p}>.10\right)$. The proportion of reciprocally motivated customers was not found to be a significant determinant of the centrality of competing logics $(\beta=.190$, $\mathrm{p}=.15)$. Therefore, hypothesis 2 was not supported.

Hypothesis 3 predicted an increase in cross-sector workers would enhance the degree of centrality of competing logics in social enterprises. The result for the effect of the proportion of cross-sector workers on the centrality of competing logics is reported in Model 4 in Table 7, which yields not only a significant model fit for the data at the .001 level, but also is a statistically significant improvement from Model $1\left(\Delta \mathrm{R}^{2}=.021, \mathrm{p}\right.$ $<.05)$. In Model 4, there is an evidence that the main effect of the proportion of crosssector workers is positive and significant $(\beta=.157, \mathrm{p}=.033<.05)$. It provides strong support for hypothesis 3 .

In the final step, Model 5 included all variables in this study. I found the consistent support for hypothesis $1(\beta=.178, \mathrm{p}=.012<.05)$ and hypothesis $3((\beta=.163$, $\mathrm{p}=.024<.05)$. Model 5 still does not support for hypothesis $2(\beta=.110, \mathrm{p}=.138>.1)$. 
Table 6. Descriptive Statistics and Correlation for Study One

\begin{tabular}{|c|c|c|c|c|c|c|c|c|c|c|c|c|c|c|}
\hline & Variables & Mean & SD & 1 & 2 & 3 & 4 & 5 & 6 & 7 & 8 & 9 & 10 & 11 \\
\hline 1 & Centrality of competing logics & -4.61 & 5.41 & & & & & & & & & & & \\
\hline 2 & Total attention to issues & 10.72 & 1.86 & $.35^{* *}$ & & & & & & & & & & \\
\hline 3 & Legality (dummy) & .65 & .48 & .03 & .03 & & & & & & & & & \\
\hline 4 & Firm age $(\ln )$ & 1.61 & .62 & $-.18^{*}$ & -.13 & $-.27^{* *}$ & & & & & & & & \\
\hline 5 & Prior performance & 4.31 & 1.12 & $.20^{* *}$ & $.32^{* *}$ & -.13 & -.05 & & & & & & & \\
\hline 6 & $\begin{array}{l}\text { Attainment Discrepancy } \\
\text { (dummy) }\end{array}$ & .14 & .35 & -.12 & -.10 & -.04 & $.14^{*}$ & -.01 & & & & & & \\
\hline 7 & Debt ratio & .00 & 1.00 & -.07 & -.02 & $.15^{*}$ & -.01 & -.07 & -.05 & & & & & \\
\hline 8 & Diversity of BOD & .31 & .28 & -.06 & -.04 & -.01 & -.01 & -.07 & $.17^{*}$ & -.08 & & & & \\
\hline 9 & Duality (dummy) & .77 & .42 & -.02 & -.08 & $.24^{* *}$ & $-.15^{*}$ & -.04 & .01 & .06 & .03 & & & \\
\hline 10 & Proportion of ethical investors & .52 & .43 & .12 & .01 & -.11 & .10 & .01 & .09 & -.03 & .03 & -.12 & & \\
\hline 11 & $\begin{array}{l}\text { Proportion of reciprocally } \\
\text { motivated customers }\end{array}$ & .11 & .22 & .01 & -.12 & .02 & .13 & -.14 & .02 & .08 & .04 & .08 & .01 & \\
\hline 12 & $\begin{array}{l}\text { Proportion of cross-sector } \\
\text { workers }\end{array}$ & .23 & .38 & $.14^{*}$ & -.04 & -.02 & -.04 & -.12 & -.08 & .02 & $-.25^{* *}$ & -.03 & -.07 & .00 \\
\hline 13 & Art \& Culture (dummy) & .16 & .37 & -.07 & -.02 & $-.28^{* *}$ & $.16^{*}$ & .00 & -.09 & -.04 & .06 & .04 & .03 & -.03 \\
\hline 14 & Civil \& human rights (dummy) & .00 & .07 & -.04 & .03 & -.10 & .08 & .00 & -.03 & -.05 & .11 & -.03 & .08 & -.04 \\
\hline 15 & Economic development (dummy) & .01 & .12 & -.00 & -.01 & .00 & .07 & .02 & .07 & -.03 & .09 & -.03 & .04 & $.14^{*}$ \\
\hline 16 & Education (dummy) & .08 & .27 & .13 & .05 & .06 & -.13 & -.06 & -.06 & -.07 & -.04 & -.11 & .08 & -.02 \\
\hline 17 & Environment (dummy) & .18 & .38 & -.01 & -.04 & $.26^{* *}$ & .08 & .02 & .00 & .11 & -.02 & .03 & -.03 & .06 \\
\hline 18 & Health/healthcare (dummy) & .05 & .23 & .10 & .04 & .04 & -.06 & -.02 & .03 & .03 & .04 & .08 & -.09 & .01 \\
\hline 19 & Public service (dummy) & .08 & .27 & .03 & .00 & .06 & .05 & .02 & .04 & .10 & -.07 & .02 & .11 & $-.19^{* *}$ \\
\hline 20 & Social service type (dummy) & .05 & .22 & -.09 & -.03 & $-.17^{*}$ & .09 & $-.15^{*}$ & .11 & .05 & .09 & -.10 & -.02 & -.02 \\
\hline 21 & Work integration type (dummy) & .68 & .46 & .09 & .03 & $.21^{* *}$ & -.12 & .08 & .02 & .04 & -.01 & .05 & -.12 & -.09 \\
\hline 22 & Combination type (dummy) & .10 & .31 & -.05 & -.01 & .01 & .07 & -.05 & .05 & .02 & -.08 & .03 & -.04 & .12 \\
\hline 23 & Community-based type (dummy) & .03 & .17 & -.03 & .03 & -.06 & .01 & .00 & -.07 & -.03 & .02 & -.05 & .03 & -.08 \\
\hline
\end{tabular}




\begin{tabular}{|c|c|c|c|c|c|c|c|c|c|c|c|c|}
\hline & Variables & 12 & 13 & 14 & 15 & 16 & 17 & 18 & 19 & 20 & 21 & 22 \\
\hline 13 & Art \& Culture (dummy) & .03 & & & & & & & & & & \\
\hline 14 & Civil \& human rights (dummy) & -.04 & -.03 & & & & & & & & & \\
\hline 15 & Economic development (dummy) & -.05 & -.05 & -.01 & & & & & & & & \\
\hline 16 & Education (dummy) & .01 & -.13 & -.02 & -.04 & & & & & & & \\
\hline 17 & Environment (dummy) & .05 & $-.20^{* *}$ & -.03 & -.06 & -.14 & & & & & & \\
\hline 18 & Health/healthcare (dummy) & -.02 & -.10 & -.02 & -.03 & -.07 & -.11 & & & & & \\
\hline 19 & Public service (dummy) & -.01 & -.13 & -.02 & -.04 & -.09 & -.14 & -.07 & & & & \\
\hline 20 & Social service type (dummy) & .08 & .09 & -.02 & -.03 & .10 & -.05 & .05 & -.07 & & & \\
\hline 21 & Work integration type (dummy) & .07 & $-.38^{* *}$ & -.01 & .08 & $-.20^{* *}$ & $.17^{*}$ & -.07 & .12 & $-.34^{* *}$ & & \\
\hline 22 & Combination type (dummy) & -.11 & -.01 & $.21^{* *}$ & -.04 & $.20^{* *}$ & -.03 & .06 & -.04 & -.08 & $-.51^{* *}$ & \\
\hline 23 & Community-based type (dummy) & -.01 & .00 & -.01 & -.02 & -.05 & -.08 & -.04 & .06 & -.04 & $-.26^{* *}$ & -.06 \\
\hline
\end{tabular}


Table 7. Results of OLS Regression Model for Study One

\begin{tabular}{|c|c|c|c|c|c|}
\hline \multirow[b]{2}{*}{ Variables } & \multicolumn{5}{|c|}{ DV: Centrality of competing logics } \\
\hline & Model 1 & Model 2 & Model 3 & Model 4 & Model 5 \\
\hline Intercept & $-14.08(3.25)^{* * *}$ & $-15.22(3.25)^{* * *}$ & $-14.85(3.28)^{* * *}$ & $-15.36(3.27)^{* * *}$ & $-17.42(3.29)^{* * *}$ \\
\hline \multicolumn{6}{|l|}{ Control Variables } \\
\hline Total attention to issues & $0.80(0.21)^{* * *}$ & $0.78(0.21)^{* * *}$ & $0.82(0.21)^{* * *}$ & $0.81(0.21)^{* * *}$ & $0.80(0.21)^{* * *}$ \\
\hline Legality (dummy) & $-0.41(0.91)$ & $-0.28(0.90)$ & $-0.36(0.91)$ & $-0.34(0.90)$ & $-0.15(0.89)$ \\
\hline Firm age $(\ln )$ & $-0.66(0.66)$ & $-0.70(0.65)$ & $-0.74(0.66)$ & $-0.59(0.66)$ & $-0.70(0.65)$ \\
\hline Prior performance & $0.44(0.36)$ & $0.43(0.36)$ & $0.52(0.37)$ & $0.54(0.36)$ & $0.61(0.36)^{\dagger}$ \\
\hline Attainment Discrepancy (dummy) & $-0.90(1.11)$ & $-1.19(1.11)$ & $-0.80(1.11)$ & $-0.77(1.10)$ & $-0.97(1.09)$ \\
\hline Debt ratio & $-0.51(0.42)$ & $-0.53(0.42)$ & $-0.56(0.42)$ & $-0.51(0.42)$ & $-0.57(0.41)$ \\
\hline Diversity of BOD & $-1.27(1.42)$ & $-1.37(1.40)$ & $-1.49(1.42)$ & $-0.42(1.46)$ & $-0.72(1.44)$ \\
\hline Duality (dummy) & $0.19(0.95)$ & $0.31(0.94)$ & $0.13(0.95)$ & $0.22(0.94)$ & $0.30(0.93)$ \\
\hline Art \& Culture (dummy) & $-0.14(1.30)$ & $-0.08(1.29)$ & $-0.02(1.30)$ & $-0.33(1.29)$ & $-0.15(1.27)$ \\
\hline Civil \& human rights (dummy) & $-1.38(5.43)$ & $-2.38(5.38)$ & $-0.77(5.43)$ & $-1.59(5.37)$ & $-2.08(5.30)$ \\
\hline Economic development (dummy) & $-1.74(3.70)$ & $-1.66(3.65)$ & $-2.72(3.75)$ & $-1.48(3.66)$ & $-2.36(3.66)$ \\
\hline Education (dummy) & $2.73(1.50)$ & $2.42(1.49)$ & $2.77(1.50)^{\dagger}$ & $2.68(1.49)^{\dagger}$ & $2.39(1.47)$ \\
\hline Environment (dummy) & $0.62(1.09)$ & $0.49(1.08)$ & $0.47(1.10)$ & $0.46(1.09)$ & $0.16(1.07)$ \\
\hline Health/healthcare (dummy) & $2.86(1.75)$ & $3.08(1.74)$ & $2.81(1.75)$ & $2.77(1.74)$ & $2.95(1.71)$ \\
\hline Public service (dummy) & $0.78(1.47)$ & $0.32(1.46)$ & $0.22(1.51)$ & $0.79(1.45)$ & $-0.27(1.49)$ \\
\hline Social service type (dummy) & $-1.24(2.02)$ & $-1.15(2.00)$ & $-0.96(2.03)$ & $-1.68(2.01)$ & $-1.30(1.99)$ \\
\hline Work integration type (dummy) & $0.48(1.34)$ & $0.93(1.34)$ & $0.76(1.35)$ & $0.25(1.33)$ & $1.01(1.34)$ \\
\hline Combination type (dummy) & $-0.93(1.66)$ & $-0.39(1.66)$ & $-0.97(1.66)$ & $-0.72(1.65)$ & $-0.18(1.63)$ \\
\hline Community-based type (dummy) & $2.16(2.62)$ & $2.53(0.88)$ & $2.70(2.64)$ & $1.93(2.60)$ & $2.87(2.58)$ \\
\hline \multicolumn{6}{|l|}{ Main Effects } \\
\hline Proportion of ethical investors & & $1.81(0.89)^{*}$ & & & $2.21(0.87)^{*}$ \\
\hline Proportion of reciprocal customers & & & $2.48(1.71)$ & & $2.49(1.67)$ \\
\hline Proportion of cross-sector workers & & & & $2.27(1.05)^{*}$ & $2.36(1.04)^{*}$ \\
\hline F value & $2.19^{* * *}$ & $2.39^{* * *}$ & $2.18^{* * *}$ & $2.35^{* * *}$ & $2.60^{* * *}$ \\
\hline $\mathbf{R}^{2}$ & 0.195 & 0.220 & 0.205 & 0.216 & 0.254 \\
\hline$\Delta \mathbf{R}^{2}$ & & $0.025^{* *}$ & 0.010 & $0.021^{*}$ & $0.059^{* *}$ \\
\hline Mean VIF & 1.35 & 1.35 & 1.35 & 1.35 & 1.35 \\
\hline
\end{tabular}

$p<.10 ;{ }^{*} p<.05 ;{ }^{* *} p<.01 ;{ }^{* * *} p<.001$

$*$ Note: Unstandardized coefficient and standard error were displayed 


\section{Supplemental Analysis for Study One}

I conducted several additional analyses for robustness checks. There are four main issues to be considered: (1) the prior centrality of competing logics, (2) a potential endogeneity bias, (3) a possible non normal distribution for the proportion variables, as well as, (4) diversities within each stakeholder group.

Prior centrality of competing logics. I have theorized that the internal heterogeneity of investor, customer, and employee stakeholder groups will determine the degree of the centrality of competing logics within the social enterprises. Nonetheless, sometimes, the current level of the centrality of competing logics can be heavily influenced by the previous level of the centrality of competing logics. I controlled for the prior centrality of competing logic by incorporating labeling claims, defined as an organization's selfcategorization either to a social side or a commercial side. Institutional scholars have argued that there is a strong correlation between institutional logics and its categorization (Thornton et al., 2012). A label would use a specific word (Thornton, Ocasio, \& Lounsbury, 2012: 159) and carry both an explicit meaning and an implicit meaning (Granqvist et al., 2013). A symbolic management and market categorization perspective argues that market labels are not only important symbolic resources, but also are used by executives strategically in order to satisfy stakeholder perceptions (Granqvist et al., 2013). Prior research on institutional logics also has emphasized how they can be linked to categories (Mohr \& Duquenne, 1997; Thornton, Ocasio, \& Lounsbury, 2012). Social enterprises can categorize themselves as either a "social organization" or as a "commercial company." Therefore, I asked middle managers to indicate the extent to which his or her organization employed the mandated social organization or commercial 
company label in the organization's name prior to starting the business, adopted by Granqvist, Grodal, and Wooley (2013). The labels of both a social organization and/or a commercial company can be separately assessed using a one-item and 7-point scale ranging from 1 (strongly disagree) to 7 (strongly agree). Each label (either a social organization or a commercial company) is treated as an independent construct represented by one item. Then, I also calculated the prior centrality of competing logics by using Janis- Fadner's (1965) coefficient of imbalance.

$$
\text { Coefficient }=\frac{\left(S^{2}-S C\right)}{L^{2}} \text { if } S>C ; 0 \text { if } C=S ; \frac{\left(S C-C^{2}\right)}{L^{2}} \text { if } C>S,
$$

where $\mathrm{S}$ is the "social enterprise" label, $\mathrm{C}$ is the "commercial enterprise" label, and L is the total labeling. Lager absolute numbers of score represents a lower level of centrality for the competing institutional logics. Similarly, I reversed the absolute score of coefficient of imbalance of labeling by multiplying constant -100 so that a greater value indicates higher level of the prior centrality of competing logics. I added the prior centrality of competing logics and total labeling as additional control variables in Model 6 in the Table 8. Despite of the inclusion, the significance levels of effects have remained essentially same.

Potential endogeneity bias. It is known that if an independent variable is associated with the error term, endogeneity may occur (Kennedy, 2003). In order to check for potential endogeneity, three instrumental variables are available: (1) the existence of a blockholder, (2) the proportion of the largest customer's sales, and (3) the number of employees, all of which were regressed. Instrumental variables should be correlated with endogenous variables in the first stage; whereas, they are not related to dependent variables (Kennedy, 2003). 
The existence of a blockholder may determine the proportion of ethical investors because ownership structure may not be dispersed evenly and is often concentrated. Holderness (2009) illustrated the prevalence of this trend to concentrate ownership in $96 \%$ of US firms, meaning that they were owned by large shareholders. I controlled for blockholders as a dummy coded " 1 " if there was an investor who owned or was expected to own $50 \%$ or more of the organization, and " 0 " if there is no investor with more than $50 \%$ ownership.

If the sales of the focal organization are concentrated around a few large customers, the concentration can be directly associated with the proportion of a certain kind of customer segments, which is reciprocally motivated customers in this study. Hence, it can be inferred that the proportion of large customers is a considerable influence on the composition of customer mix in the social enterprises. Respondents were asked to gauge the relative proportion of their largest customer's sales in the total sales. The proportion of cross-sector workers can be correlated with the number of employees. I calculated the number of employees as the logarithm of the number of employee.

Then, I used two-stage least squares (2SLS) regressions with the ivregress command in STATA 13.0. In this additional analysis, the coefficients of the residual variable were not significant. Furthermore, I also conducted the Durbin-Wu-Hausman test. The result of the test suggests endogeneity is not a concern in this study $(F(3,163)$ $=.147571 ; \mathrm{p}=0.9311)$. In addition to the test for endogeneity bias, I treated these three instrumental variables as control variables. Then, I regressed these variables on the main equation. The results of the new regression are shown in Model 7 in Table 8. All significance levels of independent variables remained the same. 
Table 8. Supplementary Analysis Study One: Adding prior centrality of competing logics and other controls

\begin{tabular}{|c|c|c|c|}
\hline \multirow[b]{2}{*}{ Variables } & \multicolumn{3}{|c|}{ DV: Centrality of competing logics } \\
\hline & Model 6 & Model 7 & Model 8 \\
\hline Intercept & $-14.39(3.47)^{* * *}$ & $-17.83(3.87)^{* * *}$ & $-15.10(3.99)^{* * *}$ \\
\hline \multicolumn{4}{|l|}{ Control Variables } \\
\hline Total attention to issues & $0.91(0.22)^{* * *}$ & $0.80(0.21)^{* * *}$ & $0.91(0.22)^{* * *}$ \\
\hline Legality (dummy) & $-0.19(0.88)$ & $-0.15(0.91)$ & $-0.16(0.90)$ \\
\hline Firm age $(\ln )$ & $-0.79(0.64)$ & $-0.77(0.67)$ & $-0.84(0.67)$ \\
\hline Prior performance & $0.63(0.36)^{\dagger}$ & $0.63(0.37)^{\dagger}$ & $0.65(0.37)^{\dagger}$ \\
\hline Attainment Discrepancy (dummy) & $-0.48(1.10)$ & $-0.92(1.11)$ & $-0.47(1.11)$ \\
\hline Debt ratio & $-0.56(0.40)$ & $-0.59(0.41)$ & $-0.58(0.41)$ \\
\hline Diversity of BOD & $-0.56(1.44)$ & $-0.76(1.45)$ & $-0.56(1.45)$ \\
\hline Duality (dummy) & $0.20(0.92)$ & $0.37(0.95)$ & $0.23(0.94)$ \\
\hline Art \& Culture (dummy) & $-0.01(1.26)$ & $-0.09(1.28)$ & $0.04(1.27)$ \\
\hline Civil \& human rights (dummy) & $-1.56(5.24)$ & $-1.38(5.45)$ & $-1.05(5.39)$ \\
\hline Economic development (dummy) & $-1.85(3.62)$ & $-2.47(3.71)$ & $-1.91(3.67)$ \\
\hline Education (dummy) & $2.38(1.45)$ & $2.49(1.49)$ & $2.47(1.47)$ \\
\hline Environment (dummy) & $0.52(1.08)$ & $0.13(1.08)$ & $0.49(1.09)$ \\
\hline Health/healthcare (dummy) & $3.24(1.69)^{\dagger}$ & $2.98(1.74)^{\dagger}$ & $3.32(1.73)^{\dagger}$ \\
\hline Public service (dummy) & $-0.24(1.47)$ & $-0.21(1.51)$ & $-0.25(1.50)$ \\
\hline Social service type (dummy) & $-1.13(1.97)$ & $-1.14(2.02)$ & $-1.06(2.00)$ \\
\hline Work integration type (dummy) & $0.94(1.32)$ & $0.97(1.35)$ & $0.90(1.34)$ \\
\hline Combination type (dummy) & $0.11(1.62)$ & $-0.30(1.67)$ & $-0.01(1.66)$ \\
\hline Community-based type (dummy) & $2.34(2.56)$ & $2.79(2.60)$ & $2.28(2.58)$ \\
\hline \multicolumn{4}{|l|}{ Additional Control Variables } \\
\hline Prior centrality of competing logics & $0.06(0.03)^{\dagger}$ & & $0.06(0.03)^{\dagger}$ \\
\hline Total name claims & $-0.36(0.17)^{*}$ & & $-0.37(0.17)^{*}$ \\
\hline Block holder (dummy) & & $-0.08(0.91)$ & $0.16(0.91)$ \\
\hline Major customer's share & & $0.01(0.01)$ & $0.01(0.01)$ \\
\hline Number of employees $(\ln )$ & & $0.20(0.46)$ & $0.11(0.46)$ \\
\hline \multicolumn{4}{|l|}{ Main Effects } \\
\hline Proportion of ethical investors & $2.11(0.86)^{*}$ & $2.16(0.88)^{*}$ & $2.04(0.88)^{*}$ \\
\hline Proportion of reciprocal customers & $2.24(1.65)$ & $2.55(1.71)$ & $2.36(1.70)$ \\
\hline Proportion of cross-sector workers & $2.48(1.07)^{*}$ & $2.37(1.06)^{*}$ & $2.52(1.10)^{*}$ \\
\hline F value & $2.71^{* *}$ & $2.27^{* *}$ & $2.37^{* * *}$ \\
\hline $\mathbf{R}^{2}$ & 0.28 & 0.26 & 0.28 \\
\hline Mean VIF & 1.38 & 1.36 & 1.39 \\
\hline
\end{tabular}

Nonnormality of proportion variable. Third, the proportion variables may violate the normality assumption of an OLS regression. Following a suggestion by Chadwick 
and Flinchbaugh (2013), I added a constant of one to all three independent variables. Then, I transformed them into natural logs. I replaced all previous independent variables with the new log proportion of ethical investors, reciprocally motivated customers, and cross-sector workers in Model 9 in Table 9. However, the Model 9 did not change the previous results.

Diversities instead of proportions. It is possible that the centrality of competing logics was influenced by diversity within each stakeholder group, rather than by the proportion of certain characteristics of the intra stakeholder groups. In order to control for this alternative explanation, I calculated the different independent variables. To capture the degree to which investments are dispersed in a social enterprise, I used HirschmanHerfindahl index (HHI). Following the Herfindahl Index approach (Acar \& Sankaran, 1999; Herfinhdal, 1950) and adopting the categories developed by Spiess-Knafl and Achleitner (2012), I created a measure of investor diversity. The formula is $1-\sum_{i=1}^{n} P_{i}^{2}$, where $\mathrm{P}$ is the share of investment category $\mathrm{i}$ of a firm, $\mathrm{N}$ is the total number of investment categories. For the diversity of customers, I identified five categories from objective sales sources: (1) government, (2) for-profit organizations, (3) non-profit organizations, (4) other social enterprises, and (5) individual customers. Next, I calculated the diversity of customer groups using the same Herfindahl Index. In order to capture the diversity of employees, I used the same categories of employee background. The formula of $1-\sum_{i=1}^{n} P_{i}^{2}$, where $\mathrm{P}$ is the proportion of employees with a past experience category $\mathrm{i}, \mathrm{N}$ is the total number of experience categories, was used. All previous independent variables were replaced by the new diversities of investors, customers, and employees in Model 10 in Table 9. None of the 
variables showed a significant relationship associated with the centrality of competing logics.

Table 9.Supplementary Analysis Study One: Change of IVs

\begin{tabular}{|c|c|c|}
\hline \multirow{2}{*}{ Variables } & \multicolumn{2}{|c|}{ DV: Centrality of competing logics } \\
\hline & Model 9 & Model 10 \\
\hline Intercept & $-15.02(4.00)^{* * *}$ & $-10.98(3.90)^{* *}$ \\
\hline \multicolumn{3}{|l|}{ Control Variables } \\
\hline Total attention to issues & $0.91(0.22)^{* * *}$ & $0.90(0.23)^{* * *}$ \\
\hline Legality (dummy) & $-0.16(0.90)$ & $-0.12(0.93)$ \\
\hline Firm age $(\ln )$ & $-0.83(0.67)$ & $-0.47(0.69)$ \\
\hline Prior performance & $0.63(0.37)^{\dagger}$ & $0.55(0.37)$ \\
\hline Attainment Discrepancy (dummy) & $-0.49(1.11)$ & $-0.83(1.15)$ \\
\hline Debt ratio & $-0.58(0.41)$ & $-0.37(0.42)$ \\
\hline Diversity of BOD & $-0.66(1.45)$ & $-1.02(1.51)$ \\
\hline Duality (dummy) & $0.24(0.94)$ & $0.05(0.95)$ \\
\hline Art \& Culture (dummy) & $-0.02(1.27)$ & $0.40(1.33)$ \\
\hline Civil \& human rights (dummy) & $-0.98(5.39)$ & $-0.66(5.53)$ \\
\hline Economic development (dummy) & $-1.67(3.66)$ & $0.75(3.05)$ \\
\hline Education (dummy) & $2.44(1.47)$ & $2.52(1.49)^{\dagger}$ \\
\hline Environment (dummy) & $0.48(1.09)$ & $0.44(1.12)$ \\
\hline Health/healthcare (dummy) & $3.31(1.73)^{\dagger}$ & $2.30(1.87)$ \\
\hline Public service (dummy) & $-0.19(1.50)$ & $0.09(1.48)$ \\
\hline Social service type (dummy) & $-1.12(2.00)$ & $-0.48(2.04)$ \\
\hline Work integration type (dummy) & $0.85(1.34)$ & $0.48(1.34)$ \\
\hline Combination type (dummy) & $-0.06(1.65)$ & $-0.56(1.68)$ \\
\hline Community-based type (dummy) & $2.10(2.59)$ & $1.71(2.62)$ \\
\hline \multicolumn{3}{|l|}{ Additional Control Variables } \\
\hline Prior centrality of competing logics & $0.06(0.04)^{\dagger}$ & $0.07(0.04)^{\dagger}$ \\
\hline Total name claims & $-0.37(0.17)^{*}$ & $-0.32(0.17)^{\dagger}$ \\
\hline Block holder (dummy) & $0.15(0.92)$ & $-0.23(0.90)$ \\
\hline Major customer's share & $0.01(0.01)$ & $0.00(0.01)$ \\
\hline Number of employees (ln) & $0.10(0.46)$ & $-0.02(0.47)$ \\
\hline \multicolumn{3}{|l|}{ Alternative Independent Variables } \\
\hline Log percentage of ethical investors & $3.05(1.27)^{*}$ & \\
\hline Log percentage of reciprocal customers & $2.82(2.30)$ & \\
\hline Log percentage of cross-sector workers & $3.57(1.57)^{*}$ & \\
\hline \multicolumn{3}{|l|}{ Alternative Independent Variables } \\
\hline Diversity of investors & & $1.30(1.38)$ \\
\hline Diversity of customers & & $-2.86(1.75)$ \\
\hline Diversity of employees & & $-1.47(1.71)$ \\
\hline F value & $2.37^{* *}$ & $1.93^{* *}$ \\
\hline $\mathbf{R}^{2}$ & 0.28 & 0.24 \\
\hline Mean VIF & 1.38 & 1.40 \\
\hline
\end{tabular}




\section{Study Two Results}

Table 10 provides the descriptive statistics and correlations for the variables in this study. Table11 and 12 report the results of the hierarchical regression model predicting the centrality of competing logics.

Only control variables are incorporated in Model 1 in Table 11. Although a substantial amount of the variance in the centrality of competing logics can be explained by the control variables (Model $1: \mathrm{R}^{2}=.206, \mathrm{p}<0.05$ ), none of which is significantly associated with the proposed dependent variable.

Hypothesis 4 posited that there is a curvilinear relationship between a social entrepreneur's non-profit experience and the centrality of competing logics. In order to test a non-linear relationship as proposed in H4, I entered into Model 2 the linear and squared term of founder's non-profit experience (number of years and number of years ${ }^{2}$ in non-profit sectors). To support the hypothesized curvilinear relationship, the coefficient for the squared term should be positively significant on the centrality of competing logics. As shown in Model 2 in Table 11, there is a positive coefficient for the linear term for a founder's non-profit experience $(\beta=.268, p=.031<.05)$ and a negative coefficient for the squared founder's non-profit experience term $(\beta=-.343, p=.006<.01)$. Both terms were significant for the centrality of competing logics. $\mathrm{R}^{2}$ for Model 2 is .242 , which means $24.2 \%$ of the variance in the centrality of competing logics was predicted by a founder's non-profit experience. In addition, a significant change in $\mathrm{R}^{2}$ from Model 1 supports the improvement of the model $\left(\Delta \mathrm{R}^{2}=.036, \mathrm{p}<.05\right)$. This is consistent with the presence of a curvilinear relationship between a founder's non-profit experience and the centrality of competing logics, as proposed in $\mathrm{H} 4$. Thus, Hypothesis 4 received support. 
Table 10. Descriptive Statistics and Correlation for Study Two

\begin{tabular}{|c|c|c|c|c|c|c|c|c|c|c|c|c|c|c|}
\hline & Variables & Mean & SD & 1 & 2 & 3 & 4 & 5 & 6 & 7 & 8 & 9 & 10 & 11 \\
\hline 1 & Centrality of competing logics & -4.61 & 5.41 & & & & & & & & & & & \\
\hline 2 & Total attention to issues & 10.72 & 1.86 & $.35^{* *}$ & & & & & & & & & & \\
\hline 3 & Legality (dummy) & .65 & .48 & .03 & .03 & & & & & & & & & \\
\hline 4 & Firm age $(\ln )$ & 1.61 & .62 & $-.18^{*}$ & -.13 & $-.27^{* *}$ & & & & & & & & \\
\hline 5 & Prior performance & 4.31 & 1.12 & $.20^{* *}$ & $.32^{* *}$ & -.13 & -.05 & & & & & & & \\
\hline 6 & Attainment Discrepancy(dummy) & .14 & .35 & -.12 & -.10 & -.04 & $.14^{*}$ & -.01 & & & & & & \\
\hline 7 & Debt ratio & .00 & 1.00 & -.07 & -.02 & $.15^{*}$ & -.01 & -.07 & -.05 & & & & & \\
\hline 8 & Diversity of BOD & .31 & .28 & -.06 & -.04 & -.01 & -.01 & -.07 & $.17^{*}$ & -.08 & & & & \\
\hline 9 & Duality (dummy) & .77 & .42 & -.02 & -.08 & $.24^{* *}$ & $-.15^{*}$ & -.04 & .01 & .06 & .03 & & & \\
\hline 10 & Founder age (ln) & 3.90 & .18 & .02 & -.13 & -.09 & .03 & .07 & .01 & -.05 & -.08 & -.05 & & \\
\hline 11 & Founder education & 3.88 & 1.22 & .05 & .07 & $-17^{*}$ & .03 & .06 & -.04 & .03 & .03 & -.10 & -.08 & \\
\hline 12 & Founder's gender (dummy) & 1.33 & .47 & .08 & .08 & -01 & -.08 & .01 & .06 & -.13 & -.09 & -.03 & -.02 & .00 \\
\hline 13 & $\begin{array}{l}\text { Founder's commercial } \\
\text { experience (years) }\end{array}$ & 6.79 & 6.35 & $.17^{* *}$ & .09 & .07 & -.01 & .05 & -.05 & -.07 & .02 & .12 & $.21^{* *}$ & $-.23^{* *}$ \\
\hline 14 & $\begin{array}{l}\text { Founder's non-profit experience } \\
\text { (years) }\end{array}$ & 5.89 & 5.84 & -.04 & .01 & $-.26^{* *}$ & $.15^{*}$ & .07 & .11 & -.03 & .02 & $-.18^{*}$ & .07 & $.34^{* *}$ \\
\hline 15 & $\begin{array}{l}\text { Founder's Ambivalent } \\
\text { interpretation }\end{array}$ & 1.38 & 2.06 & $.17^{* *}$ & -.04 & -.04 & -.06 & .02 & -.05 & -.02 & -.08 & -.04 & $-.19^{* *}$ & -.06 \\
\hline 16 & Founder's career variety & 1.66 & 2.26 & .10 & .06 & .08 & -.14 & -.03 & -.11 & -.07 & $.15^{*}$ & .09 & $-.21^{* *}$ & -.11 \\
\hline 17 & Art \& Culture (dummy) & .16 & .37 & -.07 & -.02 & $-.28^{* *}$ & $.16^{*}$ & .00 & -.09 & -.04 & .06 & .04 & $-.15^{* *}$ & .07 \\
\hline 18 & Civil \& human rights (dummy) & .00 & .07 & -.04 & .03 & -.10 & .08 & .00 & -.03 & -.05 & .11 & -.03 & -.09 & .06 \\
\hline 19 & Economic development (dummy) & .01 & .12 & -.00 & -.01 & .00 & .07 & .02 & .07 & -.03 & .09 & -.03 & -.03 & .08 \\
\hline 20 & Education (dummy) & .08 & .27 & .13 & .05 & -.06 & -.13 & -.06 & -.06 & -.07 & -.04 & -.11 & -.11 & $.15^{*}$ \\
\hline 21 & Environment (dummy) & .18 & .38 & -.01 & -.04 & $.26^{* *}$ & .08 & .02 & .00 & .11 & -.02 & .03 & .10 & $-.14^{*}$ \\
\hline 22 & Health/healthcare (dummy) & .05 & .23 & .10 & .04 & .04 & -.06 & -.02 & .03 & .03 & .04 & .08 & -.11 & .02 \\
\hline 23 & Public service (dummy) & .08 & .27 & .03 & .00 & .06 & .05 & .02 & .04 & .10 & -.07 & .02 & .04 & .03 \\
\hline 24 & Social service type (dummy) & .05 & .22 & -.09 & -.03 & $-.17^{*}$ & .09 & $-.15^{*}$ & .11 & .05 & .09 & -.10 & -.10 & .13 \\
\hline 25 & Work integration type (dummy) & .68 & .46 & .09 & .03 & $.21^{* *}$ & -.12 & .08 & .02 & .04 & -.01 & .05 & $-.19^{* *}$ & $-.15^{*}$ \\
\hline 26 & Combination type (dummy) & .10 & .31 & -.05 & -.01 & .01 & .07 & -.05 & .05 & .02 & -.08 & .03 & -.04 & .10 \\
\hline 27 & Community-based type (dummy) & .03 & .17 & -.03 & .03 & -.06 & .01 & .00 & -.07 & -.03 & .02 & -.05 & .11 & $-.15^{*}$ \\
\hline
\end{tabular}




\begin{tabular}{|c|c|c|c|c|c|c|c|c|c|c|c|c|c|c|}
\hline & Variables & 12 & 13 & 14 & 15 & 16 & 17 & 18 & 19 & 20 & 21 & 22 & 23 & 24 \\
\hline 13 & $\begin{array}{l}\text { Founder's commercial } \\
\text { experience (years) }\end{array}$ & $-.18^{* *}$ & & & & & & & & & & & & \\
\hline 14 & $\begin{array}{l}\text { Founder's non-profit experience } \\
\text { (years) }\end{array}$ & -.13 & $-.18^{*}$ & & & & & & & & & & & \\
\hline 15 & $\begin{array}{l}\text { Founder's ambivalent } \\
\text { interpretation }\end{array}$ & -.06 & -.04 & -.08 & & & & & & & & & & \\
\hline 16 & Founder's career variety & .13 & -.09 & $-.24^{* *}$ & $.15^{*}$ & & & & & & & & & \\
\hline 17 & Art \& Culture (dummy) & .07 & -.01 & .02 & .06 & .01 & & & & & & & & \\
\hline 18 & Civil \& human rights (dummy) & .10 & -.03 & .03 & -.12 & -.02 & -.03 & & & & & & & \\
\hline 19 & Economic development (dummy) & .00 & .02 & .08 & .08 & -.04 & -.05 & -.01 & & & & & & \\
\hline 20 & Education (dummy) & $.15^{*}$ & .05 & .02 & .06 & .12 & -.13 & -.02 & -.04 & & & & & \\
\hline 21 & Environment (dummy) & $-.19^{* *}$ & .10 & -.12 & .04 & -.00 & $-.20^{* *}$ & -.03 & -.06 & -.14 & & & & \\
\hline 22 & Health/healthcare (dummy) & $.16^{*}$ & -.01 & -.01 & -.02 & -.04 & -.10 & -.02 & -.03 & -.07 & -.11 & & & \\
\hline 23 & Public service (dummy) & -.05 & .01 & -.05 & -.07 & -.02 & -.13 & -.02 & -.04 & -.09 & -.14 & -.07 & & \\
\hline 24 & Social service type (dummy) & -.06 & -.10 & $.18^{* *}$ & -.06 & -.09 & .09 & -.02 & -.03 & .10 & -.05 & .05 & -.07 & \\
\hline 25 & Community-based type (dummy) & .03 & .02 & $-.15^{*}$ & .05 & .04 & $-.38^{* *}$ & -.10 & .08 & $-.20^{* *}$ & $.17^{*}$ & -.07 & .12 & $-.34^{* *}$ \\
\hline 26 & Combination type (dummy) & $-.18^{* *}$ & .07 & -.00 & .05 & -.10 & -.01 & $.21^{* *}$ & -.04 & $.20^{* *}$ & -.03 & .06 & -.04 & -.08 \\
\hline 27 & Community-based type (dummy) & -.13 & $.17^{*}$ & .08 & -.14 & -.04 & .00 & -.01 & -.02 & -.05 & -.08 & -.04 & .06 & -.04 \\
\hline & Variables & 25 & 26 & & & & & & & & & & & \\
\hline 26 & Combination type (dummy) & $-.51^{* *}$ & & & & & & & & & & & & \\
\hline 27 & Community-based type (dummy) & $-.26^{* *}$ & -.04 & & & & & & & & & & & \\
\hline
\end{tabular}


Table 11. Results of OLS Hierarchical Regression Model for Study Two

\begin{tabular}{|c|c|c|}
\hline \multirow[b]{2}{*}{ Variables } & \multicolumn{2}{|c|}{ DV: Centrality of competing logics } \\
\hline & Model 1 & Model 2 \\
\hline Intercept & $-19.71(10.50)^{* *}$ & $-24.81(10.56)^{* *}$ \\
\hline \multicolumn{3}{|l|}{ Control Variables } \\
\hline Total attention to issues & $0.83(0.23)^{* * *}$ & $0.84(0.23)^{* * *}$ \\
\hline Legality $^{\text {a }}$ & $-0.08(0.97)$ & $-0.13(0.96)$ \\
\hline Firm age $(\ln )$ & $-0.85(0.69)$ & $-0.99(0.68)$ \\
\hline Prior performance & $0.31(0.38)$ & $0.29(0.37)$ \\
\hline Attainment Discrepancy ${ }^{a}$ & $-0.83(1.16)$ & $-1.28(1.17)$ \\
\hline Debt ratio & $-0.31(0.40)$ & $-0.28(0.40)$ \\
\hline Diversity of BOD & $-0.85(1.51)$ & $-0.61(1.48)$ \\
\hline Duality $^{\mathrm{a}}$ & $-0.13(1.00)$ & $0.24(0.99)$ \\
\hline Founder age $(\ln )$ & $0.92(2.48)$ & $2.41(2.51)$ \\
\hline Founder education & $0.34(0.35)$ & $0.26(0.36)$ \\
\hline Founder gender ${ }^{\mathrm{a}}$ & $0.47(0.92)$ & $0.86(0.93)$ \\
\hline Founder's commercial exp (yrs) & $0.12(0.07)^{\dagger}$ & $0.14(0.07) *$ \\
\hline Art \& Culture ${ }^{a}$ & $-0.02(1.38)$ & $-0.01(1.35)$ \\
\hline Civil \& human rights ${ }^{\text {a }}$ & $-1.18(5.74)$ & $-2.60(5.66)$ \\
\hline Economic development $^{\mathrm{a}}$ & $0.65(3.17)$ & $0.48(3.12)$ \\
\hline Education $^{\text {a }}$ & $2.15(1.67)$ & $2.23(1.64)$ \\
\hline Environment $^{\text {a }}$ & $0.67(1.15)$ & $0.36(1.14)$ \\
\hline Health/healthcare ${ }^{\text {a }}$ & $2.73(1.86)$ & $2.15(1.84)$ \\
\hline Public service $^{\mathrm{a}}$ & $0.99(1.51)$ & $0.66(1.50)$ \\
\hline Social service type ${ }^{a}$ & $-1.22(2.08)$ & $-1.09(2.05)$ \\
\hline Work integration type $^{a}$ & $0.21(1.40)$ & $0.49(1.38)$ \\
\hline Combination type ${ }^{a}$ & $-1.43(1.75)$ & $-1.10(1.73)$ \\
\hline Community-based type ${ }^{a}$ & $-1.43(2.64)$ & $-0.74(2.62)$ \\
\hline \multicolumn{3}{|l|}{ Main Effects } \\
\hline Founder's non-profit exp (yrs) & & $1.56(0.72)^{*}$ \\
\hline Founder's non-profit exp (yrs) ${ }^{2}$ & & $-1.25(0.45)^{* *}$ \\
\hline F value & $1.88^{*}$ & $2.01^{* *}$ \\
\hline $\mathbf{R}^{2}$ & 0.206 & 0.242 \\
\hline$\Delta \mathbf{R}^{2}$ & & $0.036^{*}$ \\
\hline Mean VIF & 1.38 & 1.56 \\
\hline
\end{tabular}


Table 12. Results of OLS Hierarchical Regression Model for Study Two

\begin{tabular}{|c|c|c|c|}
\hline \multirow[b]{2}{*}{ Variables } & \multicolumn{3}{|c|}{ DV: Centrality of competing logics } \\
\hline & Model 3 & Model 4 & Model 5 \\
\hline Intercept & $-31.72(10.65)^{* * *}$ & $-30.28(10.56)^{* * *}$ & $-32.55(10.67)^{* * *}$ \\
\hline \multicolumn{4}{|l|}{ Control Variables } \\
\hline Total attention to issues & $0.86(0.22)^{* * *}$ & $0.91(0.22)^{* * *}$ & $0.87(0.22)^{* * *}$ \\
\hline Legality $^{\mathrm{a}}$ & $0.13(0.94)$ & $-0.08(0.94)$ & $0.12(0.95)$ \\
\hline Firm age $(\ln )$ & $-0.80(0.67)$ & $-0.61(0.67)$ & $-0.69(0.68)$ \\
\hline Prior performance & $0.30(0.37)$ & $0.18(0.37)$ & $0.24(0.37)$ \\
\hline Attainment Discrepancy $^{\text {a }}$ & $-1.00(1.15)$ & $-0.94(1.14)$ & $-1.14(1.16)$ \\
\hline Debt ratio & $-0.23(0.39)$ & $-0.18(0.39)$ & $-0.14(0.40)$ \\
\hline Diversity of BOD & $-0.68(1.49)$ & $-0.71(1.47)$ & $-0.76(1.49)$ \\
\hline Duality ${ }^{\text {a }}$ & $0.42(0.98)$ & $0.55(0.97)$ & $0.56(0.99)$ \\
\hline Founder age $(\ln )$ & $3.84(2.51)$ & $3.41(2.50)$ & $3.98(2.52)$ \\
\hline Founder education & $0.37(0.36)$ & $0.38(0.36)$ & $0.36(0.36)$ \\
\hline Founder gender $^{\mathrm{a}}$ & $1.00(0.92)$ & $0.97(0.91)$ & $1.09(0.93)$ \\
\hline Founder's commercial exp (yrs) & $0.15(0.07)^{*}$ & $0.15(0.07)^{*}$ & $0.16(0.07)^{*}$ \\
\hline Art \& Culture ${ }^{a}$ & $-0.27(1.34)$ & $-0.53(1.33)$ & $-0.37(1.34)$ \\
\hline Civil \& human rights ${ }^{\text {a }}$ & $-0.29(5.63)$ & $-3.10(5.74)$ & $-0.61(5.63)$ \\
\hline Economic development ${ }^{\mathrm{a}}$ & $-0.16(3.08)$ & $-0.46(3.05)$ & $-0.11(3.09)$ \\
\hline Education $^{\mathrm{a}}$ & $1.82(1.62)$ & $1.90(1.61)$ & $1.69(1.64)$ \\
\hline Environment ${ }^{a}$ & $0.19(1.12)$ & $-0.04(1.12)$ & $0.07(1.13)$ \\
\hline Health/healthcare ${ }^{a}$ & $2.27(1.82)$ & $1.95(1.80)$ & $2.15(1.82)$ \\
\hline Public service ${ }^{\mathrm{a}}$ & $0.70(1.48)$ & $0.27(1.47)$ & $0.50(1.49)$ \\
\hline Social service type ${ }^{a}$ & $-0.72(2.03)$ & $-1.17(2.02)$ & $-0.93(2.04)$ \\
\hline Work integration type ${ }^{a}$ & $0.19(1.37)$ & $0.45(1.37)$ & $0.12(1.38)$ \\
\hline Combination type $\mathrm{a}^{\mathrm{a}}$ & $-1.50(1.73)$ & $-0.92(1.73)$ & $-1.62(1.73)$ \\
\hline Community-based type ${ }^{a}$ & $-0.16(2.58)$ & $-0.11(2.55)$ & $-0.43(2.59)$ \\
\hline \multicolumn{4}{|l|}{ Main Effects } \\
\hline Founder's non-profit exp (yrs) & $1.63(0.71)^{*}$ & $1.68(0.70)^{*}$ & $1.73(0.72)^{*}$ \\
\hline Founder's non-profit exp (yrs) ${ }^{2}$ & $-1.22(0.44)^{* *}$ & $-1.22(0.44)^{* *}$ & $-0.95(0.50)^{\dagger}$ \\
\hline Ambivalent Interpretation & $1.01(0.41)^{*}$ & $0.04(0.59)$ & $0.88(0.42)^{*}$ \\
\hline Career Variety & $0.42(0.42)$ & $0.31(0.42)$ & $-0.38(0.80)$ \\
\hline \multicolumn{4}{|l|}{ Interaction Effects } \\
\hline Non-profit $\exp (\mathrm{yrs}) \times$ Ambivalent & & $-0.85(0.67)$ & \\
\hline Non-profit exp $(\mathrm{yrs})^{2} \times$ Ambivalent & & $0.89(0.41)^{*}$ & \\
\hline Non-profit exp $(\mathrm{yrs}) \times$ Career Variety & & & $-0.42(0.84)$ \\
\hline Non-profit exp $(\mathrm{yrs})^{2} \times$ Career Variety & & & $1.07(0.76)$ \\
\hline F value & $2.31^{* *}$ & $2.47^{* * *}$ & $2.22^{* *}$ \\
\hline $\mathbf{R}^{2}$ & 0.278 & 0.303 & 0.29 \\
\hline$\Delta \mathbf{R}^{2}$ & $0.036^{*}$ & $0.025^{*}$ & $0.009^{b}$ \\
\hline Mean VIF & 1.57 & 1.87 & 1.90 \\
\hline
\end{tabular}


The curvilinear relationship between founder's non-profit experience and the centrality of competing logics is plotted as Figure 4.

Figure 4. Impact of founder's non-profit experience on the centrality of competing logics

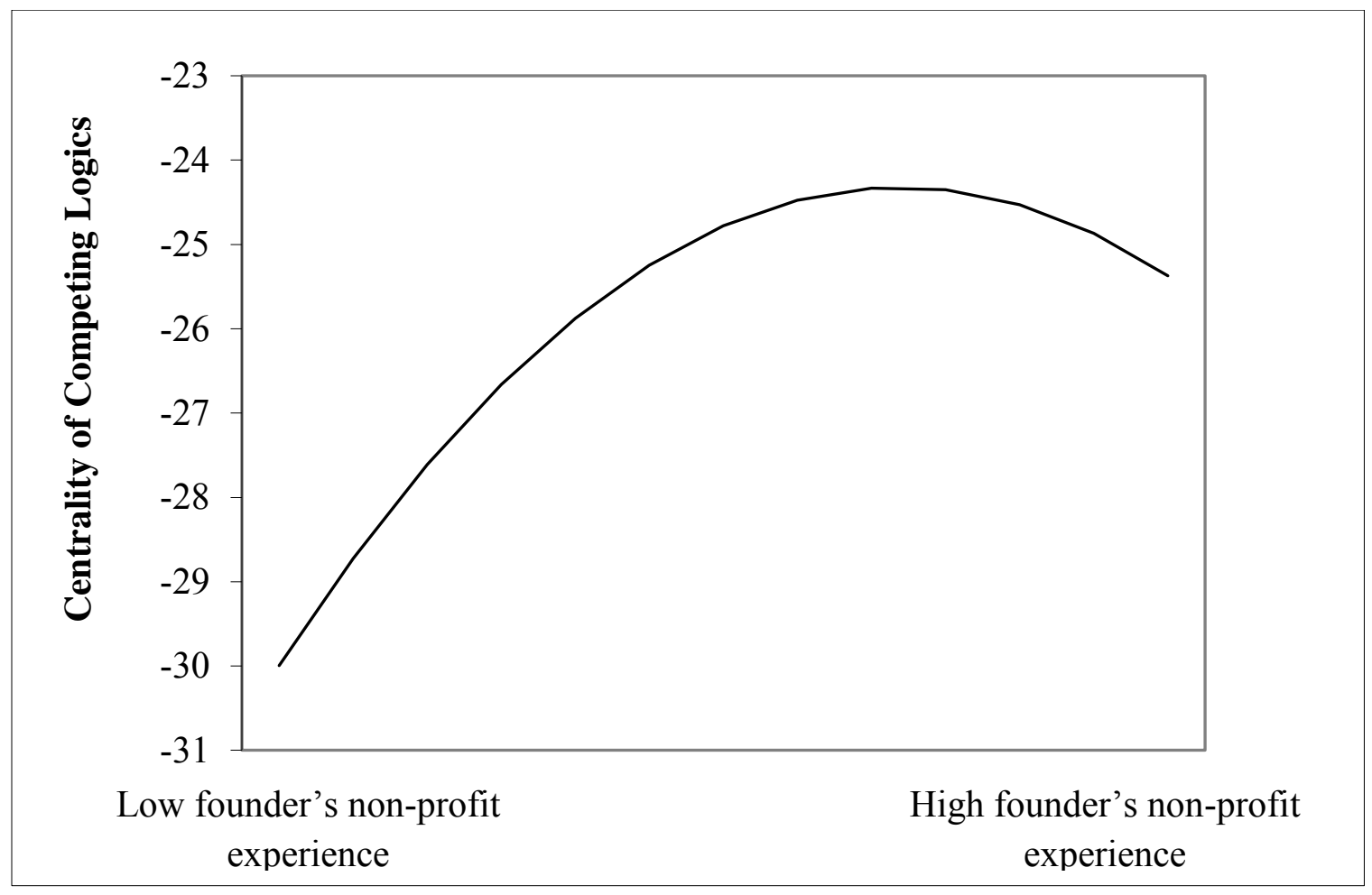

I expected the curvilinear effects of a founder's non-profit experience on the centrality of competing logics would depend on the different levels of a social entrepreneur's ambivalent interpretation and career variety. Model 3 in Table 12, thus, adds an ambivalent interpretation and career variety as moderators. Results for the direct effects of ambivalent interpretation are significant, while those for career variety are nonsignificant. Following previous research (Aiken \&West, 1991; Baron \& Kenny, 1986; Cohen \& Cohen, 1983), I added linear and quadratic-by-linear interactions of founder's non-profit experience and ambivalent interpretation in Model 4 in Table 12, as specified in Hypothesis 5. F-tests on the changes in $\mathrm{R}^{2}$ indicate that the inclusion of the interaction terms leads to a better model for the centrality of competing logics $\left(\Delta \mathrm{R}^{2}=0.025, \mathrm{p}<.01\right)$. 
The interaction term of an ambivalent interpretation $\times$ a founder's non-profit experience ${ }^{2}$ is positive and significant $(\beta=.344, \mathrm{p}=.032<.05)$, indicating that a founder's high degree of ambivalent interpretation strengthens the positive effects of low-to moderate levels of founder's non-profit experience, while reduces the negative effects of moderate to high levels of founder's non-profit experience on the centrality of competing logics.

Thus, Hypothesis 5 was supported. In order to demonstrate how ambivalent interpretation moderates the focal curvilinear relationship, Figure 5 shows that the curvilinear relationship between founders' non-profit experience and the centrality of competing logics in their social enterprises is much less profound for those with high, as opposed to low, ambivalent interpretations.

Figure 5. Impact of founder's non-profit experience on the centrality of competing logics at the low and high level of ambivalent interpretation

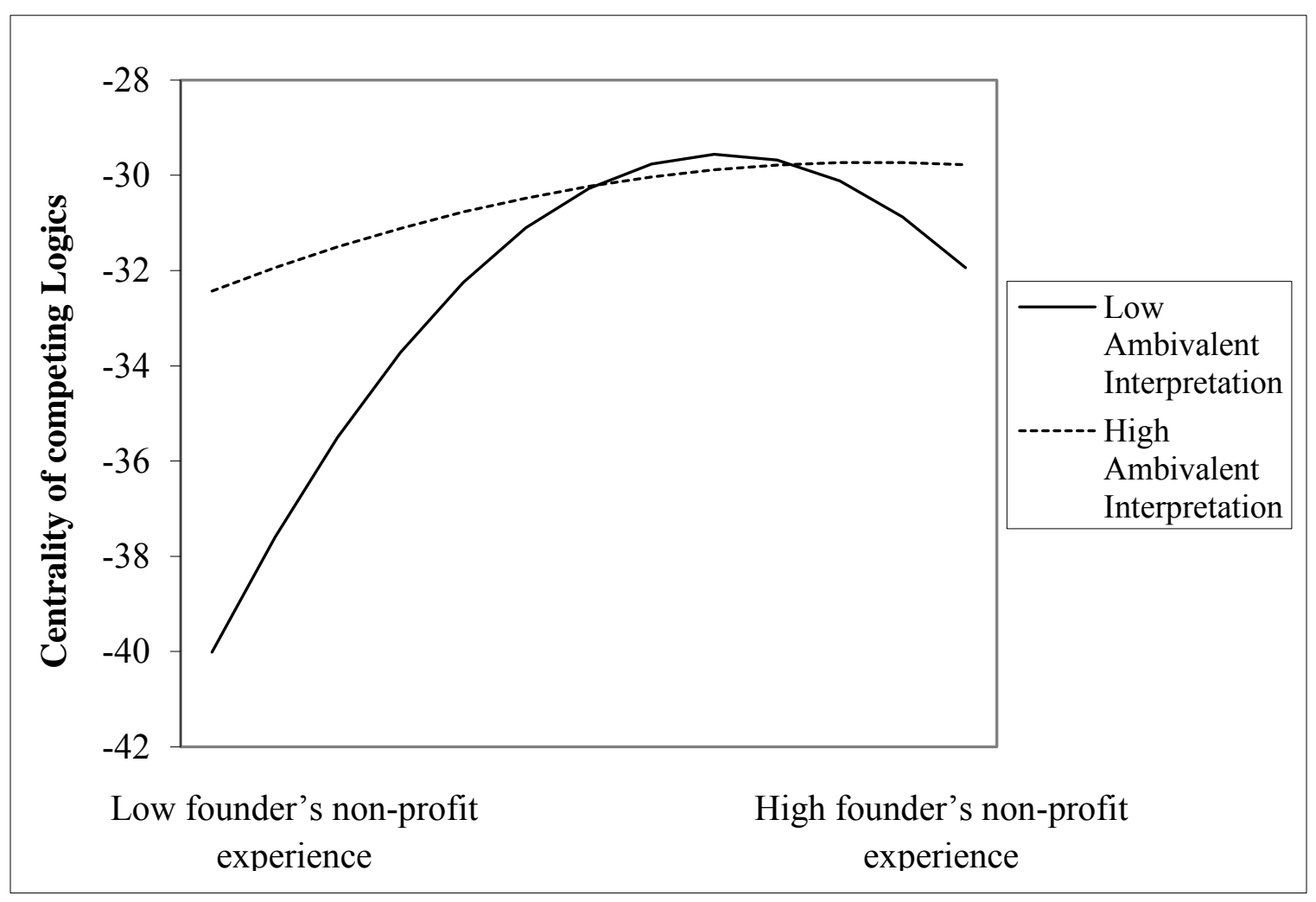


Specifically, Figure 5 reveals that both the positive and negative slopes of the relationship between a founders' non-profit experience and the centrality of competing logics are steeper for social enterprises with social entrepreneurs whose ambivalent interpretation is low. One the other hand, the curve becomes relatively flat at a high degree of ambivalent interpretation. The moderation effects of ambivalent interpretation are in the predicted direction in Hypothesis 5, which proposed that the curvilinear relationship between a level of non-profit experience of founders and the centrality of competing institutional logics will be weaker for the social enterprises with a more ambivalent social entrepreneur.

Finally, I entered the linear and quadratic-by-linear interactions of founder's nonprofit experience and career variety in Model 5 in Table 12. Hypothesis 6 predicted that the curvilinear relationship between a founder's non-profit experience and the centrality of competing logics would be less profound with a high level of a social entrepreneur's career variety. Although the direction of the effect would be in the hypothesized direction, there was no significant evidence for supporting H6 $(\beta=.199, \mathrm{p}=.161>.10)$. 


\section{Supplemental Analysis for Study Two}

To check the robustness of the findings, I conducted two additional analyses First, I controlled for the prior centrality of competing logics by re-using the coefficient of imbalance of labeling claims and the total labeling score. With additional control variables, I re-ran the whole analyses. Although these two control variables were significant through Model 6 to Model 8 in Table 13, I found no change in the results.

Second, I conducted regressions with a founder's for-profit experience as an alternative independent variable. This is quite important because recent research suggests that a founder's for-profit experience has a non-linear effect on the hybridity of the social enterprises. In the sample of 700 social venture founders, Lee and Battilana (2013) show that a social venture's level of incorporating competing logics increases as the founder's for-profit experience increases. After an average 22 years of for-profit experience, however, it is negatively associated with the hybridity. Therefore, I replaced a founder's non-profit experience with for-profit experience. Then, I re-ran the regressions from Model 9 to Model 12 in Table 14. However, I did not find significant relationship between founder's for-profit experience and centrality of competing logics. 
Table 13. Supplementary Analysis for Study Two: Adding prior centrality

\begin{tabular}{|c|c|c|c|}
\hline \multirow[b]{2}{*}{ Variables } & \multicolumn{3}{|c|}{ DV: Centrality of competing logics } \\
\hline & Model 6 & Model 7 & Model 8 \\
\hline Intercept & $-17.35(10.62)$ & $-22.80(10.78)^{*}$ & $-24.95(10.89)^{*}$ \\
\hline \multicolumn{4}{|l|}{ Control Variables } \\
\hline Total attention to issues & $0.90(0.23)^{* * *}$ & $0.97(0.23)^{* * *}$ & $0.93(0.23)^{* * *}$ \\
\hline Legality $^{\mathrm{a}}$ & $-0.16(0.94)$ & $-0.17(0.93)$ & $0.04(0.94)$ \\
\hline Firm age $(\ln )$ & $-1.01(0.67)$ & $-0.68(0.67)$ & $-0.75(0.67)$ \\
\hline Prior performance & $0.31(0.37)$ & $0.21(0.36)$ & $0.26(0.37)$ \\
\hline Attainment Discrepancy ${ }^{a}$ & $-0.80(1.15)$ & $-0.56(1.13)$ & $-0.75(1.15)$ \\
\hline Debt ratio & $-0.28(0.39)$ & $-0.19(0.38)$ & $-0.16(0.39)$ \\
\hline Diversity of BOD & $-0.59(1.46)$ & $-0.70(1.46)$ & $-0.77(1.48)$ \\
\hline Duality $^{\mathrm{a}}$ & $0.21(0.97)$ & $0.47(0.96)$ & $0.49(0.97)$ \\
\hline Founder age $(\ln )$ & $1.40(2.47)$ & $2.36(2.49)$ & $2.90(2.52)$ \\
\hline Founder education & $0.13(0.36)$ & $0.26(0.35)$ & $0.24(0.36)$ \\
\hline Founder gender ${ }^{\text {a }}$ & $1.16(0.91)$ & $1.18(0.90)$ & $1.30(0.91)$ \\
\hline Founder's commercial exp (yrs) & $0.15(0.07){ }^{*}$ & $0.16(0.07) *$ & $-0.17(0.07)^{*}$ \\
\hline Art \& Culture ${ }^{a}$ & $0.07(1.32)$ & $-0.39(1.31)$ & $-0.23(1.32)$ \\
\hline Civil \& human rights ${ }^{\text {a }}$ & $-2.40(5.54)$ & $-3.23(5.66)$ & $-0.81(5.55)$ \\
\hline Economic development ${ }^{a}$ & $1.09(3.06)$ & $0.24(3.01)$ & $0.59(3.06)$ \\
\hline Education $^{\text {a }}$ & $2.10(1.61)$ & $1.86(1.59)$ & $1.65(1.62)$ \\
\hline Environment $^{\mathrm{a}}$ & $0.85(1.13)$ & $0.41(1.11)$ & $0.53(1.12)$ \\
\hline Health/healthcare ${ }^{\mathrm{a}}$ & $2.25(1.81)$ & $2.08(1.78)$ & $2.26(1.80)$ \\
\hline Public service ${ }^{a}$ & $0.69(1.47)$ & $0.28(1.45)$ & $0.51(1.47)$ \\
\hline Social service type ${ }^{a}$ & $-0.55(2.02)$ & $-0.74(2.01)$ & $-0.50(2.02)$ \\
\hline Work integration type ${ }^{a}$ & $0.61(1.35)$ & $0.63(1.35)$ & $0.31(1.36)$ \\
\hline Combination type ${ }^{a}$ & $-0.64(1.71)$ & $-0.39(1.74)$ & $-1.08(1.73)$ \\
\hline Community-based type ${ }^{a}$ & $-0.72(2.56)$ & $0.02(2.51)$ & $-0.50(2.55)$ \\
\hline \multicolumn{4}{|l|}{ Additional Control Variables } \\
\hline Prior Centrality & $0.09(0.03)^{* *}$ & $0.08(0.03)^{*}$ & $0.08(0.03)^{*}$ \\
\hline Total name claims & $-0.38(0.17)^{*}$ & $-0.35(0.17)^{*}$ & $-0.34(0.17)^{*}$ \\
\hline \multicolumn{4}{|l|}{ Main Effects } \\
\hline Founder's non-profit exp (yrs) & $1.66(0.71)^{*}$ & $1.80(0.71)^{*}$ & $1.84(0.73)^{*}$ \\
\hline Founder's non-profit exp (yrs) ${ }^{2}$ & $-1.24(0.44)^{* *}$ & $-1.24(0.44)^{* *}$ & $-0.96(0.50)^{\dagger}$ \\
\hline Ambivalent Interpretation & & $-0.12(0.58)$ & $0.70(0.42)^{\dagger}$ \\
\hline Career Variety & & $0.31(0.41)$ & $-0.35(0.79)$ \\
\hline \multicolumn{4}{|l|}{ Interaction Effects } \\
\hline Non-profit $\exp (\mathrm{yrs}) \times$ Ambivalent & & $-0.82(0.67)$ & \\
\hline Non-profit exp (yrs) $2 \times$ Ambivalent & & $0.86(0.41)^{*}$ & \\
\hline Non-profit exp $(\mathrm{yrs}) \times$ Career Variety & & & $-0.37(0.83)$ \\
\hline Non-profit exp (yrs) $2 \times$ Career Variety & & & $1.05(0.75)$ \\
\hline F value & $2.38^{* * *}$ & $2.54^{* * *}$ & $2.37^{* * *}$ \\
\hline $\mathbf{R}^{2}$ & 0.28 & 0.333 & 0.318 \\
\hline Mean VIF & 1.58 & 1.87 & 1.88 \\
\hline
\end{tabular}


Table 14.Supplementary Analysis for Study Two: Change of IV to For-profit Exp

\begin{tabular}{|c|c|c|c|c|}
\hline \multirow[b]{2}{*}{ Variables } & \multicolumn{4}{|c|}{ DV: Centrality of competing logics } \\
\hline & Model 9 & Model 10 & Model 11 & Model 12 \\
\hline Intercept & $-16.14(11.07)$ & $-22.07(11.27)^{\dagger}$ & $-22.15(11.33)^{\dagger}$ & $-24.33(11.53)^{*}$ \\
\hline \multicolumn{5}{|l|}{ Control Variables } \\
\hline Total attention to issues & $0.92(0.24)^{* * *}$ & $0.93(0.23)^{* * *}$ & $0.97(0.24)^{* * *}$ & $0.96(0.24)^{* * *}$ \\
\hline Legality $^{a}$ & $-0.05(0.96)$ & $-0.16(0.95)$ & $0.15(0.97)$ & $0.22(0.97)$ \\
\hline Firm age $(\ln )$ & $-0.91(0.68)$ & $-0.75(0.68)$ & $-0.72(0.68)$ & $-0.79(0.68)$ \\
\hline Prior performance & $0.36(0.37)$ & $0.35(0.37)$ & $0.30(0.39)$ & $0.35(0.37)$ \\
\hline Attainment Discrepancy ${ }^{\text {a }}$ & $-0.23(1.16)$ & $-0.11(1.16)$ & $-0.12(1.16)$ & $-0.17(1.18)$ \\
\hline Debt ratio & $-0.30(0.40)$ & $-0.27(0.39)$ & $-0.29(0.40)$ & $-0.24(0.40)$ \\
\hline Diversity of BOD & $-0.82(1.48)$ & $-0.82(1.50)$ & $-0.86(1.51)$ & $-0.77(1.50)$ \\
\hline Duality $^{\mathrm{a}}$ & $-0.22(0.98)$ & $-0.04(0.98)$ & $-0.05(0.98)$ & $-0.06(0.98)$ \\
\hline Founder age $(\ln )$ & $0.97(2.54)$ & $2.12(2.57)$ & $2.16(2.58)$ & $2.54(2.62)$ \\
\hline Founder education & $0.29(0.37)$ & $0.37(0.36)$ & $0.36(0.37)$ & $0.42(0.37)$ \\
\hline Founder gender $^{\mathrm{a}}$ & $0.79(0.92)$ & $0.89(0.92)$ & $0.85(0.93)$ & $0.94(0.93)$ \\
\hline Founder's non-profit exp (yrs) & $0.03(0.07)$ & $0.04(0.08)$ & $0.04(0.08)$ & $0.05(0.08)^{*}$ \\
\hline Art \& Culture ${ }^{\mathrm{a}}$ & $0.22(1.35)$ & $0.04(1.35)$ & $-0.11(1.36)$ & $-0.02(1.35)$ \\
\hline Civil \& human rights ${ }^{\text {a }}$ & $-1.22(5.61)$ & $0.67(5.62)$ & $0.41(5.66)$ & $0.62(5.64)$ \\
\hline Economic development $^{\mathrm{a}}$ & $0.69(3.13)$ & $0.15(3.12)$ & $0.27(3.14)$ & $0.08(3.13)$ \\
\hline Education ${ }^{\text {a }}$ & $2.21(1.64)$ & $1.90(1.64)$ & $1.86(1.65)$ & $1.82(1.64)$ \\
\hline Environment $^{\mathrm{a}}$ & $1.17(1.14)$ & $0.97(1.13)$ & $1.01(1.17)$ & $0.89(1.17)$ \\
\hline Health/healthcare ${ }^{a}$ & $2.63(1.84)$ & $2.72(1.81)$ & $2.76(1.84)$ & $2.65(1.83)$ \\
\hline Public service $^{a}$ & $1.01(1.49)$ & $1.04(1.48)$ & $1.15(1.50)$ & $1.18(1.49)$ \\
\hline Social service type ${ }^{\text {a }}$ & $-0.51(2.05)$ & $-0.34(2.05)$ & $-0.43(2.06)$ & $-0.39(2.05)$ \\
\hline Work integration type ${ }^{a}$ & $0.25(1.37)$ & $0.02(1.37)$ & $-0.08(1.38)$ & $-0.26(1.40)$ \\
\hline Combination type ${ }^{a}$ & $-1.09(1.74)$ & $-1.49(1.75)$ & $-1.59(1.77)$ & $-1.69(1.77)$ \\
\hline Community-based type $^{\text {a }}$ & $-1.08(2.60)$ & $-0.65(2.58)$ & $-0.46(2.63)$ & $-0.77(2.59)$ \\
\hline \multicolumn{5}{|l|}{ Additional Control Variables } \\
\hline Prior Centrality & $0.09(0.04)^{*}$ & $0.08(0.04)^{*}$ & $0.08(0.04)^{*}$ & $0.07(0.04)^{\dagger}$ \\
\hline Total name claims & $-0.32(0.18)^{\dagger}$ & $-0.28(0.17)$ & $-0.29(0.18)$ & $-0.25(0.18)$ \\
\hline \multicolumn{5}{|l|}{ Main Effects-for-profit exp(yrs) } \\
\hline Founder's for-profit exp (yrs) & $1.57(0.62)^{*}$ & $1.52(0.61)^{*}$ & $1.55(0.62)^{*}$ & $1.61(0.62)^{*}$ \\
\hline Founder's for-profit exp (yrs) ${ }^{2}$ & $-0.80(0.50)$ & $-0.68(0.50)$ & $-0.66(0.52)$ & $-0.69(0.51)$ \\
\hline Ambivalent Interpretation & & $0.85(0.42)^{*}$ & $0.49(0.69)$ & $0.88(0.42)^{*}$ \\
\hline Career Variety & & $0.27(0.42)^{\dagger}$ & $0.30(0.42)$ & $0.01(0.49)$ \\
\hline \multicolumn{5}{|l|}{ Interaction Effects } \\
\hline Founder's for-profit $\exp (\mathrm{yrs}) \times$ & & & $-0.26(0.42)$ & \\
\hline \multicolumn{5}{|l|}{ Ambivalent Interpretation } \\
\hline Founder's for-profit $\exp (\mathrm{yrs})^{2 \times}$ & & & $0.36(0.53)$ & \\
\hline \multicolumn{5}{|l|}{ Ambivalent Interpretation } \\
\hline Founder's for-profit $\exp (\mathrm{yrs}) \times$ & & & & $-0.47(0.68)$ \\
\hline Career Variety & & & & \\
\hline Founder's for-profit $\exp (\mathrm{yrs})^{2} \times$ & & & & $0.55(0.55)$ \\
\hline Career Variety & & & & \\
\hline F value & $1.96^{* *}$ & $2.181^{* *}$ & $2.035^{* *}$ & $2.068^{* *}$ \\
\hline $\mathbf{R}^{2}$ & 0.260 & 0.283 & 0.285 & 0.289 \\
\hline Mean VIF & 1.53 & 1.73 & 1.73 & 1.59 \\
\hline
\end{tabular}




\section{CHAPTER 6: DISCUSSION}

Because social enterprises differ from both traditional for-profit and non-profit organizations with regard to their pursuit of a dual mission: a social mission and a commercial mission, the question of "why some social enterprises are more successful in incorporating these competing missions than others" has attracted the attention of scholars for several years (Dacin, Dacin, Matear. 2010; Doherty, Haugh, \& Lyon, 2014). Nonetheless, research addressing the conditions under which social enterprises are likely to achieve dual missions is relatively recent and, as such, is still establishing its basic tenets. Thus, the variations in a social enterprise's dual mission achievement require consideration of the organizational or individual factors that can impact centrality, which refers to the degree to which multiple logics are relevant for organizational functioning (Besharov \& Smith, 2014, p.375). This dissertation does not only attempt to propose the validated measure of the centrality of competing logics, but also specifies some of conditions under which a social enterprise's centrality of competing logics rises and falls.

My effort to study empirically any variations in the centrality of competing logics in the field of social entrepreneurship has been limited because the conceptual construct of the centrality of competing logics is just emerging in institutional logics scholarship (Besharov \& Smith, 2014). In addition, many scholars believe that social enterprises should achieve a high degree of centrality (Austin et al., 2006; Lumpkin et al., 2013). To date, research has lacked measures for centrality, which suggests a reason that there has been a dearth of empirical research with regard to the centrality of competing logics in 
the field of social entrepreneurship. Based on the assumption of value neutrality, on the other hand, I aimed to propose and test a validated instrument to capture the centrality of competing logics in social enterprises. First, I reviewed analogous constructs and theories to refine the components of the centrality of competing logics. Second, I assessed the main components of a social enterprise's centrality: top management's attention to issues associated with a social welfare logic and a commercial logic. Third, I calculated the centrality of competing logics by computing a reversed absolute score for the coefficient of imbalance. A greater score represents a higher level of centrality. Fourth, drawing on a survey from social enterprises in South Korea, I conducted several tests for the reliability and validity of the instrument. It not only demonstrates that the proposed measure of the centrality of competing logics is reliable, but also indicates that two dimensions - a social welfare logic and a commercial logic - of the centrality of competing logics are different from each other empirically.

The purpose of study1 in this dissertation was to understand how the centrality of competing logics has been affected by the heterogeneity within each stakeholder. I proposed that social enterprises with an investor stakeholder group (or shareholder group), which is rich in ethical investors (H1), customer stakeholder groups, which are rich in reciprocally motivated customers $(\mathrm{H} 2)$, and employee stakeholder groups, which are rich in cross-sector workers (H3) would enhance the centrality of their competing logics to a greater extent than those for each stakeholder groups lacking in ethical investors, reciprocally motivated customers, and cross-sector workers. Based on the assumption that financial return expectations, buying motivations, and background experiences are heterogeneous across investors, customers, and employees, respectively, I accessed each 
independent variable. The empirical results indicated that the higher portion of investors without financial return expectations was positively associated with the centrality of competing logics. This means the greater the portion of ethical investors positively influences the centrality of competing logics, which supports my first hypothesis. A similar result was generated from the test for the third hypothesis. I found social enterprises that were a higher percentage of cross-sector-workers to be more likely to have greater levels of the centrality of competing logics. However, the results do not support for the effects of customers motivated by reciprocity on centrality of competing logics. A possible explanation of this insignificant result would be that consumption itself might not be the important factor in social entrepreneurship with respect to the centrality of competing logics. Social problems with which social entrepreneurs can play a role in dealing might be the results of negative externalities - negative side effects - of production processes, not the results of consumption. (Coase, 1960; Scheuerle \& Münscher 2013).

The main objective of the study 2 was to identify the relevant dimensions of social entrepreneurs and empirically show their effects on the centrality of competing logics. I argued for the possibility of a curvilinear relationship between social entrepreneurs' non-profit experience and the centrality of competing logics (H4). Additionally, I hypothesized that a founder's ambivalent interpretation (H5) and career variety (H6) would play a moderating role in the proposed curvilinear relationship. Empirical findings demonstrated that social entrepreneurs' non-profit experience has a positive influence on the centrality of competing logics until reaching a certain point, beyond which that point is likely to be negative. Moreover, I found that the effect of 
social entrepreneurs' non-profit experience on the centrality of competing logics is less profound in the social enterprises with a highly ambivalent founder. These results are consistent with the hypotheses. However, I did not find support for the moderating effect of career variety on social entrepreneurs. Initially, I predicted that the benefits or obstacles of social entrepreneurs' non-profit experience on the centrality of competing logics would be less profound in social enterprises with a founder who has a various career paths; however, the data suggests that career variety - various professional and institutional experiences - is relatively unimportant as a moderating mechanism on the relationship between founder's non-profit experience and the centrality of competing logics. Next, I describe specific theoretical and practical contributions, followed by their interpretations.

\section{Implications for Theory and Research}

This dissertation contributes to the literature in several ways. First and foremost, this dissertation made a contribution by developing and testing a measure for the centrality of competing logics in a social entrepreneurship context. Recent research has called for easily assessed measures for social entrepreneurship's specific variables. For example, Short et al. (2009) suggest that there are chances to advance the literature of social entrepreneurship by providing relevant measures. This dissertation presents a validated and reliable measure for the centrality of competing logics. It can facilitate future research on examining the antecedents and consequences of the centrality of competing logics in social entrepreneurship context. The proposed operationalization of the centrality of competing logics allows us to access and administer the data collection with an inexpensive and easy way by reducing the complexity. 
Second, this dissertation provides empirical evidence to the literature by collecting and analyzing large-scale data. Although social entrepreneurship has received much scholarly attention, the criticism has also been raised because relatively few studies have been devoted to an analytic, detailed examination of social entrepreneurship through hypotheses testing with quantitative data. According to Short et al. (2009), only two papers out of 152 social entrepreneurship articles in their review were engaged in setting forth operational hypotheses and testing them rigorously. More empirical studies have been called for (Diochon 2010; Haugh 2012). Additionally, empirical research has been focusing more on the non-profit context; whereas, the for-profit context has not been studied extensively (Dees, 1998). With the hand-collected data from the survey of both non-for-profit and for-profit social enterprises, I theorized and tested a number of hypotheses regarding not only the direct effects of heterogeneity of intra stakeholders, but also the curvilinear effects of social entrepreneurs' non-profit experience on the centrality of competing logics. Moreover, I found and confirm the moderating effects of social entrepreneur's ambivalent interpretation.

Third, this research advances the literature on social entrepreneurship by analyzing social entrepreneurship through the lens of institutional logic. Due to the concern about coping with organizational complexity in organizations, institutional theorists have started employing a concept of "institutional logic" to institutional theory (i.e. Friedland and Alford, 1991; c.f., Greenwood et al., 2011). As a result, social enterprises have recently been recognized as organizations located in the field where two competing institutional logics co-exist preeminently. Furthermore, scholars have defined social enterprises as "born-hybrids that mix social and financial aims by their nature" 
(Wry, Lousbury, \& Jennigs, 2014: 1327). Based on the notion of competing logics inside social enterprises as hybrid-organizations, previous studies have identified a "pattern of incorporating competing logics" (Pache \& Santos, 2013) or "coordinating mechanism" (Battilana \& Dorado, 2010; Battilana et al., 2014; Dunn \& Jones, 2010; Jarzabkowski et al., 2009; Lounsbury, 2007). However, to date, there is a paucity of research on what makes the differential degrees to which these two competing logics - social welfare logic and commercial logic - are each treated as equally valid, which is the centrality of competing logics (Besharov \& Smith, 2014). Therefore, this dissertation helps to provide evidence on the conditions under which the centrality of competing logics is higher or lower.

Fourth, my dissertation also enriches the literature on the institutional theory and institutional logics by answering the call for rigorous investigation on identifying the factors that impact on the centrality of competing logics (Besharov \& Smith, 2014). Previously, institutional theorists expected that variations in the centrality of competing logics is dependent upon the resource dependence at the organization level as well as members' adherence of particular logic at the individual level (Besharov \& Smith, 2014). Building on the resource dependence proposition, the first study of this dissertation hypothesized and showed that subgroups within stakeholders may differentiate the social enterprises' dependencies upon the critical resources, which plays a significant role in shaping the centrality of competing logics. In the second study of this dissertation, following member's adherence of particular logic proposition, I was able to discern curvilinear relationship between social entrepreneurs' non-profit experience and the 
centrality of competing logics by adopting social entrepreneurs' previous work experience in non-profit sector as the adherence of social welfare logics.

Fifth, this dissertation can contribute to the organizational ambidexterity literature. In fact, institutional logics scholars also have argued that competing logics are equivalent to the idea of the trade-off activities inherent in exploitation and exploration (Greenwood et al., 2011: 351). According to organizational theory, ambidextrous organizations' simultaneously pursuit of exploitation for improving and refining products/services to meet the demands of existing markets (cf. Mueller, Rosenbusch, \& Bausch, 2013: 1610; Benner \& Tushman, 2003) as well as exploration for new knowledge, search, experimentation, and innovation (March, 1991). Scholars in this stream have focused much more on organizational structure as a key to incorporating competing activities than they have on the role of people inside organizations (Birkinshaw \& Gibson, 2004;

Siggelkow, 2003; Smith \& Tushman, 2005, see Smets, Jarzabkowski, Buke \& Spe, 2015). This dissertation, therefore, provides evidence on how the incorporation of competing logics can be enhanced by the individual dimensions such as founders and cross-sector workers.

Sixth, specifically, the first study contributes to the literature by integrating a social entrepreneurship and an intra-stakeholder perspective. Building on the heterogeneity in intra-stakeholder group (Winn, 2001), the findings revealed that the heterogeneity within stakeholders can play a role in shaping the degree of centrality of competing logics. Specifically, ethical investors within investor stakeholders and crossworkers within employee stakeholder may enhance the centrality of competing logics. The results of the first study elaborate the concept of "presence of multiple stakeholders 
in social entrepreneurship." Scholars in the field of social entrepreneurship have emphasized on the larger number of diverse stakeholders (Lumpkin et al., 2013). From the concept of heterogeneity intra stakeholder - different sub-groups within each stakeholder - this study, therefore, allow us to understand different needs from diverse stakeholders and confirm the existence of the heterogeneity within-group stakeholders. In addition, it is proved that the direct effects of subgroups of intra stakeholders on the centrality of competing logics inside social enterprises. For example, the empirical findings not only describe investor stakeholders have a varying degree of financial return expectations, but also shows how the greater portion of investor without financial return expectations can increase the centrality of competing logics.

Finally, the second study integrates an imprinting perspective and institutional logic. An imprinting perspective provides a theoretical foundation for assuming that there is a long lasting effect of individual founders on process, structures, or strategic decisions of his/her organization (Marquis \& Tilcsik, 2013). The dissertation identifies the founder's non-profit experience as a significant imprinting effect on the centrality of competing logics inside social enterprises. I found that social enterprises in which a founder's non-profit work experience was higher would be more likely to incorporate competing institutional logics. Interestingly, the relationship between the years of a founder's non-profit work experience and the centrality of competing institutional logics is a curvilinear, which means that an increase in a founder's prior non-profit work experience will enhance the centrality only up to a certain point. Beyond that point, a founder's prior non-profit work experience will decrease the centrality. In addition, the nature of this phenomenon is affected by conditions of more or less degree of social 
entrepreneur's ambivalent interpretation. In other words, the curvilinear effects of social entrepreneur's non-profit experience are less profound in the social enterprises with high level of social entrepreneurs' ambivalent interpretation.

\section{Implication for Practice}

This dissertation offers several implications for practitioners. First, monitoring the characteristics within each stakeholder groups has been extensively advised in the field of management (Kassins \& Vafeas, 2006). This dissertation also suggests that careful consideration of stakeholder characteristics can play a role in incorporating competing logics in social enterprises. Specifically, the findings of the first study indicate that financial return expectations and background experiences are heterogeneous in investor stakeholders and employee stakeholders, respectively. Moreover, I found that the greater proportion of investors whose financial return expectations are low and employees who have cross-sector work experience enable social enterprises to incorporate competing logics. At the practical level, the results implicitly suggest that attracting those investors and employees to each stakeholder group might be beneficial to incorporating competing logics.

Second, this study demonstrates the role of social entrepreneurs in shaping the centrality of competing logics. People who desire to be a social entrepreneur should be aware that non-profit experience enhances the centrality of competing logics in a social enterprise; however, it has the too-much-of-a-good-thing effect (TMGT effect, Pierce \& Aguinis, 2013) of non-profit experience. Too much working in non-profit sector can limit

one's ability to incorporate both a social mission and a commercial mission. Practitioners, policy makers, and educators should attend to the result that social entrepreneurs' too 
much time spent in the non-profit sector before starting their social enterprises might prioritize social welfare logic over commercial logic, instead of achieving dual commitment. It can be further interpreted that excessive time spent in non-profit sector might increase nonprofit worker identity more than entrepreneurial identity, which decreases "optimal identity distinctiveness." For example, Brewer (1991) suggests the model of "optimal distinctiveness," which proposes "being the same and different at the same time.” According to Brewer and her colleague (Brewer \& Pickett, 1999), optimal distinctiveness in identity can be described as "a state of being neither too distinct/independent nor too inclusive/dependent in relation to a given social identity (Kreiner, Hollensbe, Sheep, 2006: 1033). From this perspective and the results, it is important for social entrepreneurs to spend appropriate amounts of time in non-profit sector in order to be neither too social nor too commercial.

Third, this dissertation allows practitioners to understand the importance of the cognitive capabilities for the effective management of social enterprises, which is an ambivalent interpretation. I found the moderating role of a social entrepreneur's ambivalent interpretation, suggesting that when social entrepreneurs' ambivalent interpretation is high, the curvilinear relationship between a founder's non-profit experience and the centrality of competing logics is less profound. The importance of an ambivalent interpretation is consistent with "paradoxical leader behavior" (Zhang, Waldman, Han, \& Li, forthcoming). Recently, Zhang et al. (forthcoming) demonstrate that managers who engage in holistic thinking and have integrative complexity are more likely to enhance proficiency, adaptively, and proactivity. Therefore, cultivating an ambivalent interpretation would be recommended. 


\section{Limitations and Future Research}

Although this dissertation has advanced our knowledge of social entrepreneurship, it is not without limitations, which raises possibilities for future research as well. First, the dissertation primarily used the cross-sectional survey design. Therefore, any conclusions with regard to causality will be limited from an empirical point. For example, there is a possibility that the high degree of centrality of competing logics at time $1 \mathrm{might}$ attract the additional investors whose financial expectations are low at time 2, which results in a reverse causality concern. Although I have used 1 year lagged variables by asking respondents to provide both the current and 1 year lagged information, it suggests future research to conduct longitudinal designs to ensure the causal relationship.

Second, because of the extreme difficulty of collecting objective data in the field of social entrepreneurship, the data in this dissertation basically consist of "self-reported" disclosures, which can be potentially associated with recall bias and social desirability bias. I argue that these concerns are minimal in this study because several remedies already have been applied. For example, following the suggestions of previous research (Eisenhardt, 1989), respondents were asked to "go back in time (Miller, Cardinal, \& Glick, 1997)" and remind them of facts, not their opinion in time. Then, they reported the objective information such as the number of employees. In addition, similarly to previous research (Monteiro, forthcoming); I made respondents aware that the data would be aggregated, reviewed by only me, and used for research purposes only. In order to avoid social desirability bias in self-reported data, I also followed the suggestion of multiple informants (Kumar, Stern \& Anderson, 1993). After collecting independent variables and control variables, I contacted middle managers as the new informants to acquire 
dependent variable data. Nonetheless, the dissertation suggests that future research can benefit from more objective data sources, or different approaches such as natural experiments or simulation methods.

Third, although usage of accredited Korean social enterprises not only makes it possible to conduct large-scale empirical analysis, but also allows us to avoid the identification problem of social entrepreneurship, I acknowledge this dissertation is conducted in a single country. In terms of the generalizability of my results, it is possible that the results of this research were not separated from the effects of government-driven policy in the Korean context. From replicating the proposed models in other country contexts, future research might not only establish the generalizability, but also find more interesting role of different public authorities.

Forth, this dissertation treated the centrality of competing logics as the dependent variable only. It is because the purpose of this dissertation is focusing on antecedents of the centrality of competing logics. Because it is beyond the scope of the research, I do not make any claims that achieving a high level of centrality is superior because a high level of the centrality can be also a source of internal conflicts. Hence, the centrality of competing logics can be used as independent variable for other important dependent variables such as social impacts, social or commercial performance, internal conflicts, and innovation. Furthermore, there may be different usages of the centrality of competing logics based on the interests of future researchers. In some cases, scholars can use the centrality of competing logics as a moderator or a mediator.

Fifth, beyond investor, customer, and employees, there are many different types of stakeholders associated with social entrepreneurship. For example, community (Haugh, 
2007), government (Nicholls \& Pharoah, 2007), and fellowship organizations such as Ashoka foundation (Nicholls, 2010b) would be considered as powerful stakeholders that can have impact on the centrality of competing logics.

Sixth, I believe that future research can benefit from identifying other important contingent factors for the relationships proposed in this dissertation. For example, extant research suggests that a top manager's own preference should be examined carefully. Building on agency theory and optimal contracting theory, Masulis and Reza (2015) showed that there is a positive relationship between corporate charitable giving and a CEO's charitable preferences. Future research could investigate whether social entrepreneurs' preference could moderate the relationship between their non-profit experience and the centrality of competing logics. 


\section{REFERENCES}

Acar, W., \& Sankaran, K. (1999). The myth of the unique decomposability: specializing the Herfindahl and entropy measures? Strategic Management Journal, 20(10), 969-975.

Adams, J. S. (1965). Inequity in social exchange. Advances in Experimental Social Psychology, 2(267-299).

Adams, R. B., Licht, A. N., \& Sagiv, L. (2011). Shareholders and stakeholders: How do directors decide? Strategic Management Journal, 32(12), 1331-1355.

Adler, P. S., \& Kwon, S.-W. (2002). Social capital: Prospects for a new concept. Academy of Management Review, 27(1), 17-40.

Agle, B. R., Mitchell, R. K., \& Sonnenfeld, J. A. (1999). Who matters to Ceos? An investigation of stakeholder attributes and salience, corpate performance, and Ceo values. Academy of Management Journal, 42(5), 507-525.

Aguinis, H. (1995). Statistical power with moderated multiple regression in management research. Journal of Management, 21(6), 1141-1158.

Ahuja, G., Lampert, C. M., \& Tandon, V. (2008). Moving Beyond Schumpeter: Management Research on the Determinants of Technological Innovation. The Academy of Management Annals, 2(1), 1-98.

Aiken, L. S., \& West, S. G. (1991). Multiple regression: Testing and interpreting interactions. Newbury Park, CA: Sage. 
Allan, B. (2005). Social enterprise: through the eyes of the consumer (prepared for the National Consumer Council). Social Enterprise Journal, 1(1), 57-77.

Almandoz, J. (2012). Arriving at the starting line: The impact of community and financial logics on new banking ventures. Academy of Management Journal, 55(6) 13811406.

Alvarez, S. A., \& Barney, J. B. (2005). How do entrepreneurs organize firms under conditions of uncertainty? Journal of Management, 31(5), 776-793.

Amato, L. H., \& Amato, C. H. (2007). The effects of firm size and industry on corporate giving. Journal of Business Ethics, 72(3), 229-241.

Ames, D. R., Flynn, F. J., \& Weber, E. U. (2004). It's the thought that counts: On perceiving how helpers decide to lend a hand. Personality and Social Psychology Bulletin, 30(4), 461-474.

Amit, R., \& Schoemaker, P. J. (1993). Strategic assets and organizational rent. Strategic Management Journal, 14(1), 33-46.

Anderson, E. W., Fornell, C., \& Lehmann, D. R. (1994). Customer satisfaction, market share, and profitability: Findings from Sweden. The Journal of Marketing, 53-66.

Anderson, E. W., \& Sullivan, M. W. (1993). The antecedents and consequences of customer satisfaction for firms. Marketing Science, 12(2), 125-143.

Aneshensel, C. S., \& Pearlin, L. I. 1987. Structural contexts of sex differences in stress.

Anheier, H. K. (2005). Nonprofit Organizations: An Introduction: Theory, Management, Policy. Routledge.

Andreoni, J. (1989). Giving with impure altruism: applications to charity and Ricardian equivalence. The Journal of Political Economy, 1447-1458. 
Andreoni, J. (1990). Impure altruism and donations to public goods: a theory of warmglow giving. The Economic Journal, 464-477.

Ansoff, H. I. (1975). Managing Strategic Surprise by Response to Weak Signals. California Management Review, 18(2).

Armstrong, J. S., \& Overton, T. S. (1977). Estimating nonresponse bias in mail surveys. Journal of Marketing Research, 396-402.

Arora, P., \& Dharwadkar, R. (2011). Corporate governance and corporate social responsibility (CSR): The moderating roles of attainment discrepancy and organization slack. Corporate Governance: An International Review, 19(2), 136152.

Ashforth, B. E., Reingen, P. H., \& Ward, J. C. 2009. Friend and foe? The dynamics of duality in a cooperative. Working paper, Arizona State University.

Astebro, T., \& Thompson, P. (2011). Entrepreneurs, Jacks of all trades or Hobos? Research Policy, 40(5), 637-649.

Austin, J., Stevenson, H., \& Wei-Skillern, J. (2006). Social and commercial entrepreneurship: same, different, or both? Entrepreneurship Theory and Practice, 30(1), 1-22.

Bacq, S., Hartog, C., \& Hoogendoorn, B. (2014). Beyond the Moral Portrayal of Social Entrepreneurs: An Empirical Approach to Who They Are and What Drives Them. Journal of Business Ethics, 1-16.

Baer, M., Leenders, R. T. A., Oldham, G. R., \& Vadera, A. K. (2010). Win or lose the battle for creativity: The power and perils of intergroup competition. Academy of Management Journal, 53(4), 827-845. 
Baliga, B., Moyer, R. C., \& Rao, R. S. (1996). CEO duality and firm performance: what's the fuss? Strategic Management Journal, 17(1), 41-53.

Barnett, M. L., \& Salomon, R. M. (2012). Does it pay to be really good? Addressing the shape of the relationship between social and financial performance. Strategic Management Journal, 33(11), 1304-1320.

Baron, D. P. (1995). The nonmarket strategy system. Sloan Management Review, 37, $73-$ 73.

Baron, J. N., Hannan, M. T., \& Burton, M. D. (1999). Building the iron cage: Determinants of managerial intensity in the early years of organizations. American Sociological Review, 527-547.

Baron, J. N., Hannan, M. T., \& Burton, M. D. (2001). Labor Pains: Change in Organizational Models and Employee Turnover in Young, High-Tech Firms1. American Journal of Sociology, 106(4), 960-1012.

Baron, R. M., \& Kenny, D. A. (1986). The moderator-mediator variable distinction in social psychological research: Conceptual, strategic, and statistical considerations. Journal of Personality and Social Psychology, 51(6), 1173.

Bartunek, J. M. (1984). Changing interpretive schemes and organizational restructuring: The example of a religious order. Administrative Science Quarterly, 355-372.

Bateman, T. S., \& Zeithaml, C. P. (1989). The psychological context of strategic decisions: A model and convergent experimental findings. Strategic Management Journal, 10(1), 59-74.

Batson, C. D. (1987). Prosocial motivation: Is it ever truly altruistic? Advanced in Experimental Social Psychology, 20, 65-122. 
Battilana, J., \& Dorado, S. (2010). Building sustainable hybrid organizations: The case of commercial microfinance organizations. Academy of Management Journal, 53(6), 1419-1440.

Battilana, J., Leca, B., \& Boxenbaum, E. (2009). How actors change institutions: towards a theory of institutional entrepreneurship. The Academy of Management Annals, $3(1), 65-107$.

Battilana, J., Sengul, M., Pache, A.-C., \& Model, J. (2014). Harnessing productive tensions in hybrid organizations: The case of work integration social enterprises. Academy of Management Journal, conditionally accepted.

Baum, J. A., Rowley, T. J., Shipilov, A. V., \& Chuang, Y.-T. (2005). Dancing with strangers: Aspiration performance and the search for underwriting syndicate partners. Administrative Science Quarterly, 50(4), 536-575.

Bazerman, M., \& Moore, D. A. (2008). Judgment in managerial decision making. Wiley, Chichester, $U K$.

Beal, D. J., Goyen, M., \& Philips, P. (2005). Why do we invest ethically? The Journal of Investing, 14(3), 66-78.

Bebchuk, L. A. (2005). The case for increasing shareholder power. Harvard Law Review, 833-914.

Becker, G. S. (1964). Human capital: a theoretical analysis with special reference to education. New York: Columbia University Press.

Becker, G. S. (1975). Human Capital, 2nd. Edition. New York.

Beckman, C. M. (2006). The influence of founding team company affiliations on firm behavior. Academy of Management Journal, 49(4), 741-758. 
Beckman, C. M., \& Haunschild, P. R. (2002). Network learning: The effects of partners' heterogeneity of experience on corporate acquisitions. Administrative Science Quarterly, 47(1), 92-124.

Belsey, D. A., Kuh, E., \& Welsch, R. E. (1980). Regression diagnostics: Identifying influential data and sources of collinearity. John Wiley.

Benner, M. J., \& Tripsas, M. (2012). The influence of prior industry affiliation on framing in nascent industries: the evolution of digital cameras. Strategic Management Journal, 33(3), 277-302.

Benner, M. J., \& Tushman, M. L. (2003). Exploitation, exploration, and process management: The productivity dilemma revisited. Academy of Management Review, 28(2), 238-256.

Besharov, M. L., \& Smith, W. K. (2014). Multiple Institutional Logics in Organizations: Explaining Their Varied Nature and Implications. Academy of Management Review, 39(3), 364-381.

Bidet, E. (2012). Overcoming Labor Market Problems and Providing Social Services: Government and Civil Society Collaboration in South Korea. Nonprofit and Voluntary Sector Quarterly, 41(6), 1215-1230.

Bidet, E., \& Eum, H.-S. (2011). Social enterprise in South Korea: history and diversity. Social Enterprise Journal, 7(1), 69-85.

Birkinshaw, J., \& Gibson, C. (2004). Building ambidexterity into an organization. MIT Sloan Management Review, 45, 47-55.

Blau, P. M. (1977). Inequality and heterogeneity: A primitive theory of social structure (Vol. 7). Free Press New York. 
Boeker, W. (1989). Strategic change: The effects of founding and history. Academy of Management Journal, 32(3), 489-515.

Boeker, W., \& Karichalil, R. (2002). Entrepreneurial transitions: Factors influencing founder departure. Academy of Management Journal, 45(4), 818-826.

Borzaga, C., \& Tortia, E. (2006). Worker motivations, job satisfaction, and loyalty in public and nonprofit social services. Nonprofit and Voluntary Sector Quarterly, $35(2), 225-248$.

Boschee, J. (2008). A key lesson business can teach charities. Chronicle of Philanthropy, $18,41-43$.

Bower, J. L., \& Gilbert, C. G. (2007). How managers' everyday decisions create-or destroy-your company's strategy. Harvard Business Review, 85(2), 72.

Bowles, S. (1998). Endogenous preferences: The cultural consequences of markets and other economic institutions. Journal of Economic Literature, 75-111.

Brammer, S., \& Millington, A. (2008). Does it pay to be different? An analysis of the relationship between corporate social and financial performance. Strategic Management Journal, 29(12), 1325-1343.

Brealey, R. A., Myers, S. C., \& Marcus, A. J. (n.d.). Fundamentals of Corporate Finance (New York, 1995). McGraw-Hill Publishing.

Brewer, M. B. (1991). The social self: On being the same and different at the same time. Personality and Social Psychology Bulletin, 17(5), 475-482.

Brewer, M. B., \& Pickett, C. L. (1999). Distinctiveness motives as a source of the social self. In T. R. Tyler, R. M. Kramer, and 0. P. John (eds.), The Psychology of the Social Self: 71-87. Mahwah, NJ: Eribaum 
Bridoux, F., \& Stoelhorst, J. W. (2014). Microfoundations for stakeholder theory: Managing stakeholders with heterogeneous motives. Strategic Management Journal, 35(1), 107-125.

Brislin, R. W. (1970). Back-translation for cross-cultural research. Journal of CrossCultural Psychology, 1(3), 185-216.

Burke, P. J., \& Tully, J. C. (1977). The measurement of role identity. Social Forces, $55(4), 881-897$.

Burton, M. D., Sørensen, J. B., \& Beckman, C. M. (2002a). Coming from good stock: Career histories and new venture formation. In Research in the Sociology of Organizations: Social Structure and Organizations Revisited, Vol. 19. JAI Press: Greenwich, CT; 229-262

Buysse, K., \& Verbeke, A. (2003). Proactive environmental strategies: a stakeholder management perspective. Strategic Management Journal, 24(5), 453-470.

Cao, Q., Gedajlovic, E., \& Zhang, H. (2009). Unpacking organizational ambidexterity: Dimensions, contingencies, and synergistic effects. Organization Science, 20(4), $781-796$.

Cao, Q., Maruping, L. M., \& Takeuchi, R. (2006). Disentangling the effects of CEO turnover and succession on organizational capabilities: A social network perspective. Organization Science, 17(5), 563-576.

Cao, Q., Simsek, Z., \& Jansen, J. J. (2012). CEO Social Capital and Entrepreneurial Orientation of the Firm Bonding and Bridging Effects. Journal of Management, article-in-press. 
Carpenter, M. A., Sanders, W. G., \& Gregersen, H. B. (2001). Bundling human capital with organizational context: The impact of international assignment experience on multinational firm performance and CEO pay. Academy of Management Journal, 44(3), 493-511.

Carroll, A. B. (1995). Stakeholder thinking in three models of management morality: a perspective with strategic implications. Understanding Stakeholder Thinking, 4774.

Carroll, G. R., \& Mosakowski, E. (1987). The career dynamics of self-employment. Administrative Science Quarterly, 570-589.

Carter, N. M., Gartner, W. B., Shaver, K. G., \& Gatewood, E. J. (2003). The career reasons of nascent entrepreneurs. Journal of Business Venturing, 18(1), 13-39.

Cassar, G. (2014). Industry and startup experience on entrepreneur forecast performance in new firms. Journal of Business Venturing, 29(1), 137-151.

Chadwick, C., \& Flinchbaugh, C. (2013). The effects of part-time workers on establishment financial performance. Journal of Management, 0149206313511116.

Chandler, G. N., \& Jansen, E. (1992). The founder's self-assessed competence and venture performance. Journal of Business Venturing, 7(3), 223-236.

Chapman, T., Forbes, D., \& Brown, J. (2007). "They have God on their side": the impact of public sector attitudes on the development of social enterprise. Social Enterprise Journal, 3(1), 78-89. 
Chattopadhyay, P., Glick, W. H., \& Huber, G. P. (2001). Organizational actions in response to threats and opportunities. Academy of Management Journal, 44(5), 937-955.

Chell, E. (2007). Social enterprise and entrepreneurship towards a convergent theory of the entrepreneurial process. International Small Business Journal, 25(1), 5-26.

Chiu, S.-C., \& Sharfman, M. (2009). Legitimacy, visibility, and the antecedents of corporate social performance: An investigation of the instrumental perspective. Journal of Management. Published online on Oct 19, 2009.

Clarkson, M. E. (1995). A stakeholder framework for analyzing and evaluating corporate social performance. Academy of Management Review, 20(1), 92-117.

Coase, R. H. (1960). Problem of social cost, the. JL \& Econ., 3, 1.

Cohen, J., \& Cohen, P. (1984). Applied Multiple Regression/Correlation Analysis for the Behavioral Sciences (2 edition). Hillsdale, N.J: Psychology Press.

Cohen, J., Cohen, P., West, S. G., \& Aiken, L. S. (2002). Applied Multiple Regression/Correlation Analysis for the Behavioral Sciences, 3rd Edition (Third edition). Mahwah, N.J: Routledge.

Cohen, W. M., \& Levinthal, D. A. (1990). Absorptive capacity: a new perspective on learning and innovation. Administrative Science Quarterly, 128-152.

Conry, J. C. (1998). Gender and pay equity in the fundraising workforce: Implications for practice and policy. New Directions for Philanthropic Fundraising, 1998(19), 7392.

Cooper, A. C. (1986). The role of incubator organizations in the founding of growthoriented firms. Journal of Business Venturing, 1(1), 75-86. 
Cooper, A. C., Gimeno-Gascon, F. J., \& Woo, C. Y. (1994). Initial human and financial capital as predictors of new venture performance. Journal of Business Venturing, 9(5), 371-395.

Copeland Thomas, E., Koller, T., \& Murrin, J. (1994). Valuation: measuring and managing the value of companies. Wiley Frontiers in Finance.

Cronqvist, H., \& Fahlenbrach, R. (2009). Large shareholders and corporate policies. Review of Financial Studies, 22(10), 3941-3976.

Crossland, C., Zyung, J., Hiller, N., \& Hambrick, D. (2013). CEO career variety: Effects on firm-level strategic and social novelty. Academy of Management Journal, amj2012.

Cummings, J. L., \& Doh, J. (2000). Identifying who matters: mapping key players in multiple environments. California Management Review, 42(2), 83-104.

Cyert, R. M., March, J. G., \& others. (1963). A behavioral theory of the firm. Englewood Cliffs, NJ, 2.

Dacin, M. T., Dacin, P. A., \& Tracey, P. (2011). Social entrepreneurship: A critique and future directions. Organization Science, 22(5), 1203-1213.

Daily, C. M., \& Dalton, D. R. (1992). The relationship between governance structure and corporate performance in entrepreneurial firms. Journal of Business Venturing, 7(5), 375-386.

Daily, C. M., McDougall, P. P., Covin, J. G., \& Dalton, D. R. (2002). Governance and strategic leadership in entrepreneurial firms. Journal of Management, 28(3), 387412. 
Dart, R. (2004). The legitimacy of social enterprise. Nonprofit Management and Leadership, 14(4), 411-424.

David, P., Bloom, M., \& Hillman, A. J. (2007). Investor activism, managerial responsiveness, and corporate social performance. Strategic Management Journal, 28(1), 91-100.

Dawson, S. (1988). Four motivations for charitable giving: implications for marketing strategy to attract monetary donations for medical research. Journal of Health Care Marketing, 8(2), 31-37.

Dean, J. W., \& Sharfman, M. P. (1996). Does decision process matter? A study of strategic decision-making effectiveness. Academy of Management Journal, 39(2), $368-392$.

De Cooman, R., De Gieter, S., Pepermans, R., \& Jegers, M. (2011). A cross-sector comparison of motivation-related concepts in for-profit and not-for-profit service organizations. Nonprofit and Voluntary Sector Quarterly. forthcoming.

Deephouse, D. L. (1996). Does isomorphism legitimate? Academy of Management Journal, 39(4), 1024-1039.

Dees, J. G. (1998). The meaning of social entrepreneurship. Stanford Business School Centre for Social Innovation.

Dees, J. G., \& Anderson, B. B. (2003). For-Profit Social Ventures. International Journal of Entrepreneurship Education (special issue on social entrepreneurship), 2, 1-26.

Dees, J. G., \& Anderson, B. B. (2006). Framing a theory of social entrepreneurship: Building on two schools of practice and thought. Research on Social 
Entrepreneurship: Understanding and Contributing to an Emerging Field, 1(3), $39-66$.

Dees, J. G., Emerson, J., \& Economy, P. (2002). Enterprising nonprofits: A toolkit for social entrepreneurs (Vol. 186). John Wiley \& Sons.

Dees, J. G., Emerson, J., \& Economy, P. (2004). Strategic tools for social entrepreneurs: Enhancing the performance of your enterprising nonprofit (Vol. 207). John Wiley $\&$ Sons.

Defourny, J., \& Nyssens, M. (2008). Social enterprise in Europe: recent trends and developments. Social Enterprise Journal, 4(3), 202-228.

Delmar, F., \& Shane, S. (2006). Does experience matter? The effect of founding team experience on the survival and sales of newly founded ventures. Strategic Organization, 4(3), 215-247.

Denison, D. R., Dutton, J. E., Kahn, J. A., \& Hart, S. L. (1996). Organizational context and the interpretation of strategic issue: A note on CEOs' interpretations of foreign investment. Journal of Management Studies, 33(4), 453-474.

De Pelsmacker, P., Driesen, L., \& Rayp, G. (2005). Do consumers care about ethics? Willingness to pay for fair-trade coffee. Journal of Consumer Affairs, 39(2), 363385 .

Desa, G., \& Basu, S. (2013). Optimization or bricolage? Overcoming resource constraints in global social entrepreneurship. Strategic Entrepreneurship Journal, 7(1), 2649.

Di Gregorio, D., \& Shane, S. (2003). Why do some universities generate more start-ups than others? Research Policy, 32(2), 209-227. 
Dillman, D. A. (1978). Mail and telephone surveys (Vol. 3). Wiley Interscience.

DiMaggio, P. J. (1988). Interest and agency in institutional theory. Institutional Patterns and Organizations: Culture and Environment, 1, 3-22.

Diochon, M. C. (2010). Governance, entrepreneurship and effectiveness: exploring the link. Social Enterprise Journal, 6(2), 93-109.

Dobrev, S. D., \& Barnett, W. P. (2005). Organizational roles and transition to entrepreneurship. Academy of Management Journal, 48(3), 433-449.

Doherty, B., Haugh, H., \& Lyon, F. (2014). Social enterprises as hybrid organizations: A review and research agenda. International Journal of Management Reviews, $16(4), 417-436$.

Dooley, L. M., \& Lindner, J. R. (2003). The handling of nonresponse error. Human Resource Development Quarterly, 14(1), 99-110.

Dunn, M. B., \& Jones, C. (2010). Institutional logics and institutional pluralism: The contestation of care and science logics in medical education, 1967-2005. Administrative Science Quarterly, 55(1), 114-149.

Dutton, J. E. (1997). Strategic agenda building in organizations. Organizational Decision Making, 81, 105.

Dutton, J. E., \& Duncan, R. B. (1987). The creation of momentum for change through the process of strategic issue diagnosis. Strategic Management Journal, 8(3), 279295.

Dyer, J. H., \& Chu, W. (2003). The role of trustworthiness in reducing transaction costs and improving performance: Empirical evidence from the United States, Japan, and Korea. Organization Science, 14(1), 57-68. 
Ebrahim, A., Battilana, J., \& Mair, J. (2014). The governance of social enterprises: Mission drift and accountability challenges in hybrid organizations. Research in Organizational Behavior, 34, 81-100.

Edelman, L. B. (1990). Legal environments and organizational governance: The expansion of due process in the American workplace. American Journal of Sociology, 1401-1440.

Edwards, J. R., \& Rothbard, N. P. 2000. Mechanisms linking work and family: Clarifying the relationship between work and family constructs. Academy of Management Review, 25(1): 178-199.

Eesley, C., \& Lenox, M. J. (2006). Firm responses to secondary stakeholder action. Strategic Management Journal, 27(8), 765-781.

Egelhoff, W. G. (1982). Strategy and structure in multinational corporations: An information-processing approach. Administrative Science Quarterly, 435-458.

Einolf, C. J. (2009). Will the boomers volunteer during retirement? Comparing the baby boom, silent, and long civic cohorts. Nonprofit and Voluntary Sector Quarterly, 38(2), 181-199.

Eisenhardt, K. M. (1989). Making fast strategic decisions in high-velocity environments. Academy of Management Journal, 32(3), 543-576.

Emerson, J., \& Twersky, F. (1996). New social entrepreneurs: The success, challenge and lessons of non-profit enterprise creation. San Francisco: Roberts Foundation, Homeless Economic Development Fund 
Fassin, Y., \& Gosselin, D. (2011). The collapse of a European bank in the financial crisis: an analysis from stakeholder and ethical perspectives. Journal of Business Ethics, 102(2), 169-191.

Fattoum, A., \& Delmar, F. (2012). Founder Status, Defensive Mechanisms and IPO Underpricing. Frontiers of Entrepreneurship Research, 32(5), 1.

Fauchart, E., \& Gruber, M. (2011). Darwinians, communitarians, and missionaries: the role of founder identity in entrepreneurship. Academy of Management Journal, 54(5), 935-957.

Fern, M. J., Cardinal, L. B., \& O’Neill, H. M. (2012). The genesis of strategy in new ventures: Escaping the constraints of founder and team knowledge. Strategic Management Journal, 33(4), 427-447.

Fisman, R., Heal, G., \& Nair, V. B. (2006). A model of corporate philanthropy. Working paper, The Wharton School, University of Pennsylvania

Fligstein, N. (1985). The spread of the multidivisional form among large firms, 19191979. Advances in Strategic Management, 17, 55-78.

Fligstein, N. (1987). The intraorganizational power struggle: Rise of finance personnel to top leadership in large corporations, 1919-1979. American Sociological Review, $44-58$.

Fligstein, N. (1997). Social skill and institutional theory. American Behavioral Scientist, 40(4), 397-405.

Fligstein, N., \& Brantley, P. (1992). Bank control, owner control, or organizational dynamics: Who controls the large modern corporation? American Journal of Sociology, 280-307. 
Fornell, C. (1992). A national customer satisfaction barometer: The Swedish experience. The Journal of Marketing, 6-21.

Foster, W., \& Bradach, J. (2005). Should nonprofit seek profits. Harvard Business Review, 83(2), 92-100.

Fowler, A. (2000). NGDOs as a moment in history: beyond aid to social entrepreneurship or civic innovation? Third World Quarterly, 21(4), 637-654.

Freeman, R. E. (1984). Strategic management: A stakeholder approach. Cambridge University Press.

Freeman, R. E., Wicks, A. C., \& Parmar, B. (2004). Stakeholder theory and "the corporate objective revisited." Organization Science, 15(3), 364-369.

Friedland, R., \& Alford, R. R. (1991). Bringing society back in: Symbols, practices and institutional contradictions. In W. W. Powell \& P. J. DiMaggio (Eds.). The New Institutionalism in Organizational Analysis, 232-267.

Friedman, M. (1955). The role of government in education. Rutgers University Press.

Friedman, M. (1962). Capitalism and freedom. University of Chicago press.

Frooman, J. (1999). Stakeholder influence strategies. Academy of Management Review, 24(2), 191-205.

Frumkin, P. (2003). Inside venture philanthropy. Society, 40(4), 7-15.

Geletkanycz, M. A., Boyd, B. K., \& Finkelstein, S. (2001). The strategic value of CEO external directorate networks: Implications for CEO compensation. Strategic Management Journal, 22(9), 889-898.

Gimeno, J., Folta, T. B., Cooper, A. C., \& Woo, C. Y. (1997). Survival of the fittest? Entrepreneurial human capital and the persistence of underperforming firms. Administrative Science Quarterly, 750-783. 
Ginsberg, A., \& Venkatraman, N. (1995). Institutional initiatives for technological change: From issue interpretation to strategic choice. Organization Studies, 16(3), $425-448$.

Gioia, D. A., \& Chittipeddi, K. (1991). Sensemaking and sensegiving in strategic change initiation. Strategic Management Journal, 12(6), 433-448.

Gittelman, M., \& Kogut, B. (2003). Does good science lead to valuable knowledge? Biotechnology firms and the evolutionary logic of citation patterns. Management Science, 49(4), 366-382.

Glac, K. (2009). Understanding socially responsible investing: The effect of decision frames and trade-off options. Journal of Business Ethics, 87(1), 41-55.

Glynn, M. A. (2000). When cymbals become symbols: Conflict over organizational identity within a symphony orchestra. Organization Science, 11(3), 285-298.

Godos-Díez, J.-L., Fernández-Gago, R., \& Martínez-Campillo, A. (2011). How important are CEOs to CSR practices? An analysis of the mediating effect of the perceived role of ethics and social responsibility. Journal of Business Ethics, 98(4), 531548.

Golden, B. R., \& Zajac, E. J. (2001). When will boards influence strategy? Inclination x power= strategic change. Strategic Management Journal, 22(12), 1087-1111.

Gollier, C., \& Pouget, S. (2012). Asset prices and corporate behavior with socially responsible investors. Working Paper.

Gonin, M., Besharov, M. H.-P., \& Smith, W. K. (2013). Managing Social-Business Tensions: A Review and Research Agenda for Social Enterprises. In Academy of Management Proceedings (Vol. 2013, p. 11745). 
Gough, I. (2001). Social assistance regimes: a cluster analysis. Journal of European Social Policy, 11(2), 165-170.

Granqvist, N., Grodal, S., \& Woolley, J. L. (2013). Hedging your bets: Explaining executives' market labeling strategies in nanotechnology. Organization Science, 24(2), 395-413.

Grant, A. M. (2008). Does intrinsic motivation fuel the prosocial fire? Motivational synergy in predicting persistence, performance, and productivity. Journal of Applied Psychology, 93(1), 48.

Greenhaus, J. H., Collins, K. M., \& Shaw, J. D. (2003). The relation between workfamily balance and quality of life. Journal of Vocational Behavior, 63(3), 510531.

Greenwood, R., Díaz, A. M., Li, S. X., \& Lorente, J. C. (2010). The multiplicity of institutional logics and the heterogeneity of organizational responses. Organization Science, 21(2), 521-539.

Greenwood, R., \& Hinings, C. R. (1996). Understanding radical organizational change: Bringing together the old and the new institutionalism. Academy of Management Review, 21(4), 1022-1054.

Greenwood, R., Raynard, M., Kodeih, F., Micelotta, E. R., \& Lounsbury, M. (2011). Institutional complexity and organizational responses. The Academy of Management Annals, 5(1), 317-371.

Grichnik, D., Brinckmann, J., Singh, L., \& Manigart, S. (2014). Beyond environmental scarcity: Human and social capital as driving forces of bootstrapping activities. Journal of Business Venturing, 29(2), 310-326. 
Gruber, M., MacMillan, I. C., \& Thompson, J. D. (2008). Look before you leap: Market opportunity identification in emerging technology firms. Management Science, 54(9), 1652-1665.

Guclu, A., Dees, J. G., \& Anderson, B. B. (2002). The process of social entrepreneurship: Creating opportunities worthy of serious pursuit. Center for the Advancement of Social Entrepreneurship, 1-15.

Hair, J. F. J., Black, W. C., Babin, B. J., \& Anderson, R. E. (2009). Multivariate Data Analysis (7 edition). Upper Saddle River, NJ: Prentice Hall.

Hansmann, H. B. (1980). The role of nonprofit enterprise. Yale Law Journal, 835-901.

Harris, L. C., \& Ogbonna, E. (1999). The strategic legacy of company founders. Long Range Planning, 32(3), 333-343.

Harrison, J. S., Bosse, D. A., \& Phillips, R. A. (2010). Managing for stakeholders, stakeholder utility functions, and competitive advantage. Strategic Management Journal, 31(1), 58-74.

Harrison, J. S., \& Freeman, R. E. (1999). Stakeholders, social responsibility, and performance: empirical evidence and theoretical perspectives. Academy of Management Journal, 42(5), 479-485.

Harrison, D. A., \& Klein, K. J. (2007). What's the difference? Diversity constructs as separation, variety, or disparity in organizations. Academy of Management Review, 32(4), 1199-1228.

Harrison, J. S., \& John, C. H. S. (1996). Managing and partnering with external stakeholders. The Academy of Management Executive, 10(2), 46-60. 
Haugh, H. (2007). Community-led social venture creation. Entrepreneurship Theory and Practice, 31(2), 161-182.

Haugh, H. (2012). The importance of theory in social enterprise research. Social Enterprise Journal, 8(1), 7-15.

Haveman, H. A., \& Rao, H. (1997). Structuring a theory of moral sentiments: institutional and organizational coevolution in the early thrift industry. American Journal of Sociology, 102(6), 1606-1651.

He, Z.-L., \& Wong, P.-K. 2004. Exploration vs. exploitation: An empirical test of the ambidexterity hypothesis. Organization Science, 15(4): 481-494.

Heavey, C., \& Simsek, Z. (in press). Distributed Cognition in Top Management Teams and Organizational Ambidexterity The Influence of Transactive Memory Systems. Journal of Management

Henriques, I., \& Sadorsky, P. (1999). The relationship between environmental commitment and managerial perceptions of stakeholder importance. Academy of Management Journal, 42(1), 87-99.

Herfindahl, O. C. (1950). Concentration in the steel industry. Columbia University. Hervieux, C., Gedajlovic, E., \& Turcotte, M.-F. B. (2010). The legitimization of social entrepreneurship. Journal of Enterprising Communities: People and Places in the Global Economy, 4(1), 37-67.

Hibbert, S. A., Hogg, G., \& Quinn, T. (2005). Social entrepreneurship: Understanding consumer motives for buying The Big Issue. Journal of Consumer Behaviour, 4(3), 159-172.

Hill, K. (2011). Investor perspectives on social enterprise financing. London: City of London. 
Hill, C. W., \& Snell, S. A. (1988). External control, corporate strategy, and firm performance in research-intensive industries. Strategic Management Journal, 9(6), 577-590.

Hillman, A. J., \& Dalziel, T. (2003). Boards of directors and firm performance: Integrating agency and resource dependence perspectives. Academy of Management Review, 28(3), 383-396.

Hillman, A. J., Withers, M. C., \& Collins, B. J. (2009). Resource dependence theory: A review. Journal of Management. 35, 1404-1427

Hirsch, P. M. (1997). Sociology Without Social Structure: Neoinstitutional Theory Meets Brave New World. American Journal of Sociology, 102(6), 1702-1723.

Hitt, M. A., Ahlstrom, D., Dacin, M. T., Levitas, E., \& Svobodina, L. (2004). The institutional effects on strategic alliance partner selection in transition economies: China vs. Russia. Organization Science, 15(2), 173-185.

Höchstädter, A. K., \& Scheck, B. (2014). What's in a Name: An Analysis of Impact Investing Understandings by Academics and Practitioners. Journal of Business Ethics, 1-27.

Holderness, C. G. (2009). The myth of diffuse ownership in the United States. Review of Financial Studies, 22(4), 1377-1408.

Hoogendoorn, B., Pennings, E., \& Thurik, R. (2009). What do we know about social entrepreneurship: An analysis of empirical research. International Review of Entrepreneurshp, 8(2), 71-112. 
Hopp, C. (2012). For Better or for Worse?-Nonprofit Experience and the Performance of Nascent Entrepreneurs. Nonprofit and Voluntary Sector Quarterly, 41(6), $1251-1268$.

Hoskisson, R. E., Hitt, M. A., Johnson, R. A., \& Grossman, W. (2002). Conflicting voices: The effects of institutional ownership heterogeneity and internal governance on corporate innovation strategies. Academy of Management Journal, 45(4), 697-716.

Howard, B. (2008). Understanding the LOHAS market. Skin Inc. Magazine.

Jackson, S. E., \& Dutton, J. E. (1988). Discerning threats and opportunities. Administrative Science Quarterly, 370-387.

Jain, B. A., \& Tabak, F. (2008). Factors influencing the choice between founder versus non-founder CEOs for IPO firms. Journal of Business Venturing, 23(1), 21-45.

Jain, S., George, G., \& Maltarich, M. (2009). Academics or entrepreneurs? Investigating role identity modification of university scientists involved in commercialization activity. Research Policy, 38(6), 922-935.

Janis, I. L., \& Fadner, R. H. (1965). The coefficient of imbalance. In H. Lasswell, N. Leites, \& Associates (Eds.). Language of Politics, 153-169.

Jansen, J. J., Van Den Bosch, F. A., \& Volberda, H. W. 2005. Managing potential and realized absorptive capacity: how do organizational antecedents matter? Academy of Management Journal, 48(6): 999-1015.

Jarzabkowski, P., \& Paul Spee, A. (2009). Strategy-as-practice: A review and future directions for the field. International Journal of Management Reviews, 11(1), 6995. 
Jawahar, I. M., \& McLaughlin, G. L. (2001). Toward a descriptive stakeholder theory: An organizational life cycle approach. Academy of Management Review, 26(3), $397-414$.

Jay, J. (2012). Navigating paradox as a mechanism of change and innovation in hybrid organizations. Academy of Management Journal, 56(1), 137-159.

Jensen, M., \& Meckling, W. H. (1976). Theory of the firm: Managerial behavior, agency costs and ownership structure. Journal of Financial Economics, 3(4), 305-360.

Johnson, V. (2007). What Is Organizational Imprinting? Cultural Entrepreneurship in the Founding of the Paris Opera1. American Journal of Sociology, 113(1), 97-127.

Jones, M. B. (2007). The multiple sources of mission drift. Nonprofit and Voluntary Sector Quarterly, 36(2), 299-307.

Judge, W. Q., \& Zeithaml, C. P. (1992). Institutional and strategic choice perspectives on board involvement in the strategic decision process. Academy of Management Journal, 35(4), 766-794.

Julian, S. D., \& Ofori-Dankwa, J. C. (2006). Is accreditation good for the strategic decision making of traditional business schools? Academy of Management Learning \& Education, 5(2), 225-233.

Kahneman, D., Slovic, P., \& Tversky, A. (Eds.). (1982). Judgment Under Uncertainty: Heuristics and Biases (1 edition). Cambridge ; New York: Cambridge University Press.

Kaplan, A. (1964). The conduct of inquiry: methodology for behavioral science. Chandler Pub. Co. 
Kaplan, S. N., \& Minton, B. A. (1994). Appointments of outsiders to Japanese boards: Determinants and implications for managers. Journal of Financial Economics, $36(2), 225-258$.

Kassinis, G., \& Vafeas, N. (2006). Stakeholder pressures and environmental performance. Academy of Management Journal, 49(1), 145-159.

Keller, R. T. (2001). Cross-functional project groups in research and new product development: Diversity, communications, job stress, and outcomes. Academy of Management Journal, 44(3), 547-555.

Kennedy, P. (2003). A guide to econometrics. MIT press.

Kerlin, J. A. (2006). Social enterprise in the United States and abroad: Learning from our differences. Research on Social Enterpreneurship, ARNOVA Occasional Paper Series, 1(3), 105-125.

Kimberly, J. R. (1979). Issues in the creation of organizations: Initiation, innovation, and institutionalization. Academy of Management Journal, 22(3), 437-457.

Kimberly, J. R., \& Bouchikhi, H. (1995). The dynamics of organizational development and change: How the past shapes the present and constrains the future. Organization Science, 6(1), 9-18.

Kim, T.-Y., Shin, D., Oh, H., \& Jeong, Y.-C. (2007). Inside the iron cage: Organizational political dynamics and institutional changes in presidential selection systems in Korean universities, 1985-2002. Administrative Science Quarterly, 52(2), 286323.

Kirchmeyer, C. 2000. Work-life initiatives: greed or benevolence regarding workers' time? Trends in Organizational Behavior, 7: 79-94. 
Kistruck, G. M., \& Beamish, P. W. (2010). The interplay of form, structure, and embeddedness in social intrapreneurship. Entrepreneurship Theory and Practice, $34(4), 735-761$.

Klingebiel, R., \& Rammer, C. (2014b). Resource allocation strategy for innovation portfolio management. Strategic Management Journal, 35(2), 246-268.

Kogut, B., \& Zander, U. (1992). Knowledge of the firm, combinative capabilities, and the replication of technology. Organization Science, 3(3), 383-397.

Kolympiris, C., Kalaitzandonakes, N., \& Miller, D. (2014). Location choice of academic entrepreneurs: Evidence from the US biotechnology industry. Journal of Business Venturing. 30(2), 227-254

Korosec, R. L., \& Berman, E. M. (2006). Municipal support for social entrepreneurship. Public Administration Review, 66(3), 448-462.

Koschate-Fischer, N., Stefan, I. V., \& Hoyer, W. D. (2012). Willingness to pay for causerelated marketing: the impact of donation amount and moderating effects. Journal of Marketing Research, 49(6), 910-927.

Kotha, R., \& George, G. (2012). Friends, family, or fools: Entrepreneur experience and its implications for equity distribution and resource mobilization. Journal of Business Venturing, 27(5), 525-543.

Kraatz, M. S., \& Block, E. S. (2008). Organizational implications of institutional pluralism. The Sage Handbook of Organizational Institutionalism, 840, 243-275.

Kreiner, G. E., Hollensbe, E. C., \& Sheep, M. L. (2006). Where is the "me" among the "we"? Identity work and the search for optimal balance. Academy of Management Journal, 49(5), 1031-1057. 
Kriauciunas, A., \& Kale, P. (2006). The impact of socialist imprinting and search on resource change: A study of firms in Lithuania. Strategic Management Journal, 27(7), 659-679.

Kriauciunas, A., Parmigiani, A., \& Rivera-Santos, M. (2011). Leaving our comfort zone: Integrating established practices with unique adaptations to conduct survey-based strategy research in nontraditional contexts. Strategic Management Journal, 32(9), 994-1010.

Kroll, M., Walters, B. A., \& Wright, P. (2008). Board vigilance, director experience, and corporate outcomes. Strategic Management Journal, 29(4), 363-382.

Kuhnle, S. (2003). Survival of the European welfare state. Routledge.

Kumar, N., Stern, L. W., \& Anderson, J. C. (1993). Conducting interorganizational research using key informants. Academy of Management Journal, 36(6), 16331651.

Kutner, M. H., Nachtsheim, C., \& Neter, J. (2004). Applied linear regression models. McGraw-Hill/Irwin.

Landier, A., \& Thesmar, D. (2009). Financial contracting with optimistic entrepreneurs. Review of Financial Studies, 22(1), 117-150.

Laroche, M., Bergeron, J., \& Barbaro-Forleo, G. (2001). Targeting consumers who are willing to pay more for environmentally friendly products. Journal of Consumer Marketing, 18(6), 503-520.

Lavie, D., Stettner, U., \& Tushman, M. L. 2010. Exploration and exploitation within and across organizations. The Academy of Management Annals, 4(1): 109-155. 
Leblebici, H., Salancik, G. R., Copay, A., \& King, T. (1991). Institutional change and the transformation of interorganizational fields: An organizational history of the US radio broadcasting industry. Administrative Science Quarterly, 333-363.

Lechner, C., Frankenberger, K., \& Floyd, S. W. (2010). Task contingencies in the curvilinear relationships between intergroup networks and initiative performance. Academy of Management Journal, 53(4), 865-889.

Lee, C., Lee, K., \& Pennings, J. M. (2001). Internal capabilities, external networks, and performance: a study on technology-based ventures. Strategic Management Journal, 22(6-7), 615-640.

Lee, M. (2014). Mission and Markets? The Viability of Hybrid Social Ventures. In Academy of Management Proceedings (Vol. 2014, p. 13958).

Lee, M., \& Battilana, J. (2013). How the zebra got its stripes: Imprinting of individuals and hybrid social ventures. Harvard Business School Organizational Behavior Unit Working Paper, (14-005).

Lee, P. M., \& James, E. H. (2007). She'-e-os: gender effects and investor reactions to the announcements of top executive appointments. Strategic Management Journal, $28(3), 227-241$.

Letts, C. W., Ryan, W., \& Grossman, A. (1997). Virtuous capital: What foundations can learn from venture capitalists. Harvard Business Review, 75, 36-50.

Levinthal, D. A., \& March, J. G. (1993). The myopia of learning. Strategic Management Journal, 14(S2), 95-112.

Lichtenberg, F. R., \& Siegel, D. (1991). The impact of R\&D investment on productivityNew evidence using linked R\&D-LRD data. Economic Inquiry, 29(2), 203-229. 
Lockett, A., Siegel, D., Wright, M., \& Ensley, M. D. (2005). The creation of spin-off firms at public research institutions: Managerial and policy implications. Research Policy, 34(7), 981-993.

Lounsbury, M. (2007). A tale of two cities: Competing logics and practice variation in the professionalizing of mutual funds. Academy of Management Journal, 50(2), 289-307.

Lounsbury, M. (2008). Institutional rationality and practice variation: New directions in the institutional analysis of practice. Accounting, Organizations and Society, 33(4), 349-361.

Lovallo, D., \& Sibony, O. (2010). The case for behavioral strategy. McKinsey Quarterly, $2,30-43$.

Lumpkin, G. T., Moss, T. W., Gras, D. M., Kato, S., \& Amezcua, A. S. (2013). Entrepreneurial processes in social contexts: how are they different, if at all? Small Business Economics, 40(3), 761-783.

Mackey, A., Mackey, T. B., \& Barney, J. B. (2007). Corporate social responsibility and firm performance: Investor preferences and corporate strategies. Academy of Management Review, 32(3), 817-835.

Maietta, O. W. (2003). The hedonic price of fair trade coffee for the Italian consumer. In Proceedings of the International Conference on Agricultural Policy Reform and the WTO: where are we heading.

Mairesse, J., \& Mohnen, P. (2002). Accounting for innovation and measuring innovativeness: an illustrative framework and an application. American Economic Review, 226-230. 
Mair, J., Battilana, J., \& Cardenas, J. (2012). Organizing for society: A typology of social entrepreneuring models. Journal of Business Ethics, 111(3), 353-373.

Mair, J., \& Marti, I. (2004). Social entrepreneurship: What are we talking about? A framework for future research. IESE Business School.

March, J. G. (1991). Exploration and exploitation in organizational learning. Organization Science, 2(1), 71-87.

March, J. G., \& Simon, H. A. (1958). Organizations. New York: Wiley.

Markel, K. S., \& Frone, M. R. (1998). Job characteristics, work-school conflict, and school outcomes among adolescents: Testing a structural model. Journal of Applied Psychology, 83(2), 277.

Marks, S. R., \& MacDermid, S. M. 1996. Multiple roles and the self: A theory of role balance. Journal of Marriage and the Family, 417-432.

Marquis, C., \& Lee, M. (2013). Who is governing whom? Executives, governance, and the structure of generosity in large US firms. Strategic Management Journal, 34(4), 483-497.

Marquis, C., \& Tilcsik, A. (2013). Imprinting: Toward a multilevel theory. The Academy of Management Annals, 7(1), 195-245.

Mason, C., \& Diochon, M. C. (2010). Governance, entrepreneurship and effectiveness: exploring the link. Social Enterprise Journal, 6(2), 93-109.

Masulis, R. W., \& Reza, S. W. (2015). Agency problems of corporate philanthropy. Review of Financial Studies, 28(2), 592-636.

McCall, G. J., \& Simmons, J. L. (1978). Identities and interactions: An examination of associations in everyday life (revised ed.). New York. 
McKelvey, B. (1982). Organizational systematics-taxonomy, evolution, classification. Univ of California Press.

McWilliams, A., \& Siegel, D. (2000). Research notes and communications. Corporate social responsibility and financial performance: correlation or misspecification? Strategic Management Journal, 21(5), 603-609.

Memery, J., Megicks, P., Angell, R., \& Williams, J. (2012). Understanding ethical grocery shoppers. Journal of Business Research, 65(9), 1283-1289.

Mentzer, J. T., Flint, D. J., \& Hult, G. T. M. (2001). Logistics service quality as a segment-customized process. Journal of Marketing, 65(4), 82-104.

Mersland, R., \& Strøm, R. Ø. (2010). Microfinance mission drift? World Development, $38(1), 28-36$.

Mesch, D. (2009). Women and philanthropy: A literature review. Unpublished

\section{Manuscript}

Mesch, D. J., Rooney, P. M., Steinberg, K. S., \& Denton, B. (2006). The effects of race, gender, and marital status on giving and volunteering in Indiana. Nonprofit and Voluntary Sector Quarterly, 35(4), 565-587.

Miller, C. C., Cardinal, L. B., \& Glick, W. H. (1997). Retrospective reports in organizational research: A reexamination of recent evidence. Academy of Management Journal, 40(1), 189-204.

Miller, D., Breton-Miller, L., Lester, R. H., \& others. (2011). Family and lone founder ownership and strategic behaviour: Social context, identity, and institutional logics. Journal of Management Studies, 48(1), 1-25. 
Miller, T. L., Grimes, M. G., McMullen, J. S., \& Vogus, T. J. (2012). Venturing for others with heart and head: How compassion encourages social entrepreneurship. Academy of Management Review, 37(4), 616-640.

Miller, T. L., Wesley, I. I., \& Curtis, L. (2010). Assessing mission and resources for social change: An organizational identity perspective on social venture capitalists' decision criteria. Entrepreneurship Theory and Practice, 34(4), 705-733.

Mitchell, R. K., Agle, B. R., \& Wood, D. J. (1997). Toward a theory of stakeholder identification and salience: Defining the principle of who and what really counts. Academy of Management Review, 22(4), 853-886.

Mohr, J. W., \& Duquenne, V. (1997). The duality of culture and practice: Poverty relief in New York City, 1888-1917. Theory and Society, 26(2), 305-356.

Mohr, L. A., \& Webb, D. J. (2005). The effects of corporate social responsibility and price on consumer responses. Journal of Consumer Affairs, 39(1), 121-147.

Monteiro, L. F. (forthcoming). Selective attention and the initiation of the global knowledge-sourcing process in multinational corporations. Journal of International Business Studies.

Moody, M. (2008). “ Building a Culture”: The Construction and Evolution of Venture Philanthropy as a New Organizational Field. Nonprofit and Voluntary Sector Quarterly, 37, 324-351.

Moore, M.-L., Westley, F. R., \& Nicholls, A. (2012). The Social Finance and Social Innovation Nexus 1. Journal of Social Entrepreneurship, 3(2), 115-132. 
Moss, T. W., Short, J. C., Payne, G. T., \& Lumpkin, G. T. (2011). Dual identities in social ventures: An exploratory study. Entrepreneurship Theory and Practice, $35(4), 805-830$.

Mueller, V., Rosenbusch, N., \& Bausch, A. (2013). Success patterns of exploratory and exploitative innovation a meta-analysis of the influence of institutional factors. Journal of Management, 39(6), 1606-1636.

Muller, A., \& Kolk, A. (2010). Extrinsic and intrinsic drivers of corporate social performance: Evidence from foreign and domestic firms in Mexico. Journal of Management Studies, 47(1), 1-26.

Murray, D., \& Dollery, B. (2006). Institutional breakdown? An exploratory taxonomy of Australian university failure. Higher Education Policy, 19(4), 479-494.

Nagy, R. A., \& Obenberger, R. W. (1994). Factors influencing individual investor behavior. Financial Analysts Journal, 50(4), 63-68.

Nahapiet, J., \& Ghoshal, S. (1998). Social capital, intellectual capital, and the organizational advantage. Academy of Management Review, 23(2), 242-266.

Navarro, P. (1988). Why do corporations give to charity? Journal of Business, 65-93.

Nelson, T. (2003). The persistence of founder influence: Management, ownership, and performance effects at initial public offering. Strategic Management Journal, 24(8), 707-724.

Nicholls, A. (2006). Social entrepreneurship: New models of sustainable social change. Oxford University Press.

Nicholls, A. (2010a). Fair trade: Towards an economics of virtue. Journal of Business Ethics, 92(2), 241-255. 
Nicholls, A. (2010b). The legitimacy of social entrepreneurship: reflexive isomorphism in a pre-paradigmatic field. Entrepreneurship Theory and Practice, 34(4), 611633.

Nicholls, A., \& Pharoah, C. (2007). The Landscape of Social Investment: A Holistic Topology of Opportunities and Challenges, Skoll Centre for Social Entrepreneurship Research Paper.

Ocasio, W. (1997). Towards an Attention-Based View of the Firm. Strategic Management Journal, 18(S1), 187-206.

Ohana, M., \& Meyer, M. (2010). Should I stay or should I go now? Investigating the intention to quit of the permanent staff in social enterprises. European Management Journal, 28(6), 441-454.

Oh, W. Y., Chang, Y. K., \& Martynov, A. (2011). The effect of ownership structure on corporate social responsibility: Empirical evidence from Korea. Journal of Business Ethics, 104(2), 283-297.

Oliver, C. (1991). Strategic responses to institutional processes. Academy of Management Review, 16(1), 145-179.

Oliver, C. (1992). The antecedents of deinstitutionalization. Organization Studies, 13(4), $563-588$.

Orts, E. W., \& Strudler, A. (2002). The ethical and environmental limits of stakeholder theory. Business Ethics Quarterly, 215-233.

Pache, A.-C. (2011). When competing logics enter organizations: The politics of organizational responses to conflicting institutional demands. Working Paper, ESSEC Business School, Cergy, France. 
Pache, A.-C., \& Chowdhury, I. (2012). Social entrepreneurs as institutionally embedded entrepreneurs: Toward a new model of social entrepreneurship education. Academy of Management Learning \& Education, 11(3), 494-510.

Pache, A.-C., \& Santos, F. (2010). When worlds collide: The internal dynamics of organizational responses to conflicting institutional demands. Academy of Management Review, 35(3), 455-476.

Pache, A.-C., \& Santos, F. (2012). Inside the hybrid organization: Selective coupling as a response to conflicting institutional logics. Academy of Management Journal, amj-2011.

Park, C., \& Wilding, M. (2013). Social enterprise policy design: Constructing social enterprise in the UK and Korea. International Journal of Social Welfare, 22(3), 236-247.

Parkinson, C., \& Howorth, C. (2008). The language of social entrepreneurs. Entrepreneurship and Regional Development, 20(3), 285-309.

Parmar, B. L., Freeman, R. E., Harrison, J. S., Wicks, A. C., Purnell, L., \& De Colle, S. (2010). Stakeholder theory: The state of the art. The Academy of Management Annals, 4(1), 403-445.

Parsons, T. (1951). Social system. Psychology Press.

Pelled, L. H., Eisenhardt, K. M., \& Xin, K. R. (1999). Exploring the black box: An analysis of work group diversity, conflict and performance. Administrative Science Quarterly, 44(1), 1-28. 
Peteraf, M. A., \& Bergen, M. E. (2003). Scanning dynamic competitive landscapes: a market-based and resource-based framework. Strategic Management Journal, 24(10), 1027-1041.

Petrini, C. (1995). America's competitive secret: Utilizing women as a management strategy-Rosener, JB. Oxford University Press New York.

Phillips, D. J. (2002). A genealogical approach to organizational life chances: The parentprogeny transfer among Silicon Valley law firms, 1946-1996. Administrative Science Quarterly, 47(3), 474-506.

Phillips, D. J. (2005). Organizational genealogies and the persistence of gender inequality: The case of Silicon Valley law firms. Administrative Science Quarterly, 50(3), 440-472.

Phillips, R. A., \& Reichart, J. (2000). The environment as a stakeholder? A fairnessbased approach. Journal of Business Ethics, 23(2), 185-197.

Pierce, J. L., Kostova, T., \& Dirks, K. T. (2001). Toward a theory of psychological ownership in organizations. Academy of Management Review, 26(2), 298-310.

Pierce, J. R., \& Aguinis, H. (2013). The too-much-of-a-good-thing effect in management. Journal of Management, 39(2), 313-338.

Plambeck, N., \& Weber, K. (2010). When the glass is half full and half empty: CEOs' ambivalent interpretations of strategic issues. Strategic Management Journal, 31(7), 689-710.

Pollock, T. G., \& Rindova, V. P. (2003). Media legitimation effects in the market for initial public offerings. Academy of Management Journal, 46(5), 631-642. 
Postmes, T., \& Jetten, J. (2006). Individuality and the group: Advances in social identity. Pine Forge Press.

Powell, T. C., Lovallo, D., \& Fox, C. R. (2011). Behavioral strategy. Strategic Management Journal, 32(13), 1369-1386.

Pratt, M. G., \& Foreman, P. O. (2000). Classifying managerial responses to multiple organizational identities. Academy of Management Review, 25(1), 18-42.

Preffer, J., \& Salancik, G. (1978). The external control of organizations: A resource dependence perspective. The External Control of Organizations: A Resource Dependence Perspective.

Priester, J. R., \& Petty, R. E. (1996). The gradual threshold model of ambivalence: relating the positive and negative bases of attitudes to subjective ambivalence. Journal of Personality and Social Psychology, 71(3), 431.

Ramaswamy, K., Li, M., \& Veliyath, R. (2002). Variations in ownership behavior and propensity to diversify: A study of the Indian corporate context. Strategic Management Journal, 23(4), 345-358.

Rao, H., Monin, P., \& Durand, R. (2003). Institutional Change in Toque Ville: Nouvelle Cuisine as an Identity Movement in French Gastronomy. American Journal of Sociology, 108(4), 795-843.

Rau, B. L., \& HYLAND, M. A. M. (2002). Role conflict and flexible work arrangements: The effects on applicant attraction. Personnel Psychology, 55(1), 111-136.

Rawls, J. R., Ullrich, R. A., \& Nelson, O. T. (1975). A comparison of managers entering or reentering the profit and nonprofit sectors. Academy of Management Journal, $18(3), 616-623$. 
Reay, T., \& Hinings, C. R. (2009). Managing the rivalry of competing institutional logics. Organization Studies, 30(6), 629-652.

Reichheld, F. P., \& Sasser, W. E. (1990). Zero defeciions: Quoliiy comes to services. Harvard Business Review, 68(5), 105-111.

Reid, E. M., \& Toffel, M. W. (2009). Responding to public and private politics: Corporate disclosure of climate change strategies. Strategic Management Journal, 30(11), 1157-1178.

Renneboog, L., Ter Horst, J., \& Zhang, C. (2011). Is ethical money financially smart? Nonfinancial attributes and money flows of socially responsible investment funds. Journal of Financial Intermediation, 20(4), 562-588.

Reuer, J. J., Tong, T. W., Tyler, B. B., \& Ariño, A. (2013). Executive preferences for governance modes and exchange partners: An information economics perspective. Strategic Management Journal, 34(9), 1104-1122.

Roberts, M. S. (1992). Predicting voting behavior via the agenda-setting tradition. Journalism \& Mass Communication Quarterly, 69(4), 878-892.

Rothbard, N. P. 2001. Enriching or Depleting? The Dynamics of Engagement in Work and Family Roles. Administrative Science Quarterly, 46(4): 655-684.

Romanelli, E. (1989). Environments and strategies of organization start-up: Effects on early survival. Administrative Science Quarterly, 369-387.

Rooney, P. M., Mesch, D. J., Chin, W., \& Steinberg, K. S. (2005). The effects of race, gender, and survey methodologies on giving in the US. Economics Letters, 86(2), $173-180$. 
Rubenson, G. C., \& Gupta, A. K. (1996). The initial succession: A contingency model of founder tenure. Entrepreneurship Theory and Practice, 21, 21-36.

Rudell, F. (2006). Shopping with a social conscience: Consumer attitudes toward sweatshop labor. Clothing and Textiles Research Journal, 24(4), 282-296.

Ruebottom, T. (2013). The microstructures of rhetorical strategy in social entrepreneurship: Building legitimacy through heroes and villains. Journal of Business Venturing, 28(1), 98-116.

Ruef, M., \& Scott, W. R. (1998). A multidimensional model of organizational legitimacy: Hospital survival in changing institutional environments. Administrative Science Quarterly, 877-904.

Ruvio, A. A., \& Shoham, A. (2011). A multilevel study of nascent social ventures. International Small Business Journal, 29(5), 562-579.

Ryan, L. V., \& Schneider, M. (2003). Institutional Investor Power and Heterogeneity Implications for Agency and Stakeholder Theories. Business \& Society, 42(4), $398-429$.

Ryan, R. M., \& Deci, E. L. (2000). Self-determination theory and the facilitation of intrinsic motivation, social development, and well-being. American Psychologist, 55(1), 68.

Sagiv, L., Sverdlik, N., \& Schwarz, N. (2011). To compete or to cooperate? Values' impact on perception and action in social dilemma games. European Journal of Social Psychology, 41(1), 64-77. 
Salamon, L. M. (1987). Of market failure, voluntary failure, and third-party government: Toward a theory of government-nonprofit relations in the modern welfare state. Nonprofit and Voluntary Sector Quarterly, 16(1-2), 29-49.

Sandberg, J., Juravle, C., Hedesström, T. M., \& Hamilton, I. (2009). The heterogeneity of socially responsible investment. Journal of Business Ethics, 87(4), 519-533.

Scarlata, M., \& Alemany, L. (2010). Deal structuring in philanthropic venture capital investments: Financing instrument, valuation and covenants. Journal of Business Ethics, 95(2), 121-145.

Scarlata, M., Alemany, L., \& Zacharakis, A. (2012). Philanthropic Venture Capital: Venture Capital for Social Entrepreneurs? Foundations and Trends in Entrepreneurship, 8(4).

Schilke, O., \& Cook, K. S. (2013). A cross-level process theory of trust development in interorganizational relationships. Strategic Organization, 11(3), 281-303.

Scheuerle, T., \& Münscher, R. (2013). How social value is created on markets-A taxonomy of market-based strategies by social entrepreneurs. Working paper.

Schoonhoven, C. B., \& Romanelli, E. (2001). The entrepreneurship dynamic: Origins of entrepreneurship and the evolution of industries. Stanford University Press.

Scott, W. R. (2000). Institutional change and healthcare organizations: From professional dominance to managed care. University of Chicago Press.

Scott, W. R., Ruef, M., Mendel, P., \& Caronna, C. A. (2000). Institutional change and organizations: Transformation of a healthcare field. Chicago: University of Chicago. 
Seo, M.-G., \& Creed, W. D. (2002). Institutional contradictions, praxis, and institutional change: A dialectical perspective. Academy of Management Review, 27(2), 222247.

Shane, S. (2000). Prior knowledge and the discovery of entrepreneurial opportunities. Organization Science, 11(4), 448-469.

Shane, S., \& Stuart, T. (2002). Organizational endowments and the performance of university start-ups. Management Science, 48(1), 154-170.

Shaw, E., \& Carter, S. (2007). Social entrepreneurship: Theoretical antecedents and empirical analysis of entrepreneurial processes and outcomes. Journal of Small Business and Enterprise Development, 14(3), 418-434.

Shook, C. L., Ketchen, D. J., Hult, G. T. M., \& Kacmar, K. M. (2004). An assessment of the use of structural equation modeling in strategic management research. Strategic Management Journal, 25(4), 397-404.

Short, J. C., Moss, T. W., \& Lumpkin, G. T. (2009). Research in social entrepreneurship: Past contributions and future opportunities. Strategic Entrepreneurship Journal, $3(2), 161-194$.

Siggelkow, N. (2003). Why Focus? A Study Of Intra-Industry Focus Effects. The Journal of Industrial Economics, 51(2), 121-150.

Simms, S. V., \& Robinson, J. (2009). Activist or entrepreneur? An identity-based model of social entrepreneurship. International Perspectives on Social Entrepreneurship, 9-26. 
Simsek, Z., Fox, B. C., \& Heavey, C. (2015). "What's Past Is Prologue” A Framework, Review, and Future Directions for Organizational Research on Imprinting. Journal of Management, 41(1), 288-317.

Smallbone, D., \& Lyon, F. (2005). Social enterprise development in the UK: Some contemporary policy issues. Retrieved from http://eprints.kingston.ac.uk/18635/

Smets, M., Jarzabkowski, P., Burke, G., \& Spee, P. (2014). Reinsurance Trading in Lloyd's of London: Balancing conflicting-yet-complementary logics in practice. Academy of Management Journal, forthcoming.

Smith, W. K., \& Lewis, M. W. (2011). Toward a theory of paradox: A dynamic equilibrium model of organizing. Academy of Management Review, 36(2), 381403.

Smith, W. K., Besharov, M. L., Wessels, A. K., \& Chertok, M. (2012). A paradoxical leadership model for social entrepreneurs: Challenges, leadership skills, and pedagogical tools for managing social and commercial demands. Academy of Management Learning \& Education, 11(3), 463-478.

Sørensen, J. B., \& Fassiotto, M. A. (2011). Organizations as fonts of entrepreneurship. Organization Science, 22(5), 1322-1331.

Sørensen, J. B., \& Sharkey, A. J. (2014). Entrepreneurship as a mobility process. American Sociological Review, 79(2), 328-349.

Sorenson, O., \& Stuart, T. E. (2001). Syndication networks and the spatial distribution of venture capital investments1. American Journal of Sociology, 106(6), 1546-1588. 
Spear, R., \& Bidet, E. (2005). Social enterprise for work integration in 12 european countries: a descriptive analysis*. Annals of Public and Cooperative Economics, 76(2), 195-231.

Speckbacher, G. (2008). Nonprofit versus corporate governance: An economic approach. Nonprofit Management and Leadership, 18(3), 295-320.

Spiess-Knafl, W., \& Achleitner, A.-K. (2012). Financing of Social Entrepreneurship. In Social Entrepreneurship and social business (pp. 157-173). Springer.

Stam, W., \& Elfring, T. (2008). Entrepreneurial orientation and new venture performance: The moderating role of intra-and extraindustry social capital. Academy of Management Journal, 5l(1), 97-111.

Stark, D. (2011). The sense of dissonance: Accounts of worth in economic life. Princeton University Press.

Stets, J. E., \& Burke, P. J. (2000). Identity theory and social identity theory. Social Psychology Quarterly, 224-237.

Stevens, J. M., Kevin Steensma, H., Harrison, D. A., \& Cochran, P. L. (2005). Symbolic or substantive document? The influence of ethics codes on financial executives' decisions. Strategic Management Journal, 26(2), 181-195.

Stinchcombe, A. L. (1965). Organizations and social structure. Handbook of Organizations, 44(2), 142-193.

Stinchcombe, A. L., \& March, J. G. (1965). Social structure and organizations. Advances in Strategic Management, 17, 229-259.

Stryker, S., \& Burke, P. J. (2000). The past, present, and future of an identity theory. Social Psychology Quarterly, 284-297. 
Stryker, S., \& Serpe, R. T. (1994). Identity salience and psychological centrality: Equivalent, overlapping, or complementary concepts? Social Psychology Quarterly, 16-35.

Suchard, H. T., \& Polonski, M. J. (1991). A theory of environmental buyer behaviour and its validity: the environmental action-behaviour model. In AMA Summer Educators' Conference Proceedings, American Marketing Association, Chicago, IL (Vol. 2, pp. 187-201).

Suchman, M. C. (1995). Managing legitimacy: Strategic and institutional approaches. Academy of Management Review, 20(3), 571-610.

Sundaramurthy, C., Pukthuanthong, K., \& Kor, Y. (2014). Positive and negative synergies between the CEO's and the corporate board's human and social capital: A study of biotechnology firms. Strategic Management Journal, 35(6), 845-868.

Thake, S., \& Zadek, S. (1997). Practical people, noble causes. How to Support Community Based Social Entrepreneurs. New Economic Foundation.

Thomas, J. B., Clark, S. M., \& Gioia, D. A. (1993). Strategic sensemaking and organizational performance: Linkages among scanning, interpretation, action, and outcomes. Academy of Management Journal, 36(2), 239-270.

Thomas, J. B., \& McDaniel, R. R. (1990). Interpreting strategic issues: Effects of strategy and the information-processing structure of top management teams. Academy of Management Journal, 33(2), 286-306.

Thompson, M. M., Zanna, M. P., \& Griffin, D. W. (1995). Let's not be indifferent about (attitudinal) ambivalence. Attitude Strength: Antecedents and Consequences, 4, $361-386$. 
Thornton, P. H. (1999). The sociology of entrepreneurship. Annual Review of Sociology, $19-46$.

Thornton, P. H. (2002). The rise of the corporation in a craft industry: Conflict and conformity in institutional logics. Academy of Management Journal, 45(1), 81101.

Thornton, P. H. (2004). Markets from culture: Institutional logics and organizational decisions in higher education publishing. Stanford University Press.

Thornton, P. H., \& Ocasio, W. (1999). Institutional logics and the historical contingency of power in organizations: Executive succession in the higher education publishing industry, 1958-1990. American Journal of Sociology, 105(3), 801-843.

Thornton, P. H., Ocasio, W., \& Lounsbury, M. (2012). The institutional logics perspective: A new approach to culture, structure, and process. Oxford University Press.

Tomaskovic-Devey, D., Leiter, J., \& Thompson, S. (1994). Organizational survey nonresponse. Administrative Science Quarterly, 439-457.

Tuckman, H. P., \& Chang, C. F. (2006). Commercial activity, technological change, and nonprofit mission. The Nonprofit Sector: A Research Handbook, 629-644.

Tuggle, C. S., Sirmon, D. G., Reutzel, C. R., \& Bierman, L. (2010). Commanding board of director attention: investigating how organizational performance and CEO duality affect board members' attention to monitoring. Strategic Management Journal, 31(9), 946-968.

Ulrich, D., \& Barney, J. B. (1984). Perspectives in organizations: Resource dependence, efficiency, and population. Academy of Management Review, 9(3), 471-481. 
Unger, J. M., Rauch, A., Frese, M., \& Rosenbusch, N. (2011). Human capital and entrepreneurial success: A meta-analytical review. Journal of Business Venturing, 26(3), 341-358.

Van de Ven, A. H., Sapienza, H. J., \& Villanueva, J. (2007). Entrepreneurial pursuits of self-and collective interests. Strategic Entrepreneurship Journal, 1(3-4), 353-370.

Verplanken, B., \& Holland, R. W. (2002). Motivated decision making: effects of activation and self-centrality of values on choices and behavior. Journal of Personality and Social Psychology, 82(3), 434.

Vesper, K. H. (1980). New venture strategies. Prentice-Hall.

Vidaver-Cohen, D., \& Altman, B. W. (2000). Corporate citizenship in the new millennium: Foundation for an architecture of excellence. Business and Society Review, 105(1), 145-168.

Waddock, S. A., \& Graves, S. B. (1997). The corporate social performance-financial performance link. Strategic Management Journal, 18(4), 303-319.

Walsh, J. P. (2005). Book review essay: Taking stock of stakeholder management. Academy of Management Review, 30(2), 426-438.

Wang, W.-J. (2009). Accountability in Social Enterprises: An Analytical Framework. Graduate School of Public and International Affairs University of Pittsburgh, Working Paper Series.

Wang, T., \& Bansal, P. (2012). Social responsibility in new ventures: profiting from a long-term orientation. Strategic Management Journal, 33(10), 1135-1153. 
Weaver, G. R., Trevino, L. K., \& Cochran, P. L. (1999). Integrated and decoupled corporate social performance: Management commitments, external pressures, and corporate ethics practices. Academy of Management Journal, 42(5), 539-552.

Webley, P., Lewis, A., \& Mackenzie, C. (2001). Commitment among ethical investors: An experimental approach. Journal of Economic Psychology, 22(1), 27-42.

Weisbrod, B. A. (2004). The pitfalls of profits. Stanford Social Innovation Review, 2(3), $40-47$.

Whetten, D. A., \& Mackey, A. (2002). A social actor conception of organizational identity and its implications for the study of organizational reputation. Business \& Society, 41(4), 393-414.

White, K., MacDonnell, R., \& Ellard, J. H. (2012). Belief in a just world: Consumer intentions and behaviors toward ethical products. Journal of Marketing, 76(1), $103-118$.

Williamson, O. E. (1985). The economic intstitutions of capitalism. Simon and Schuster.

Winn, M. I. (2001). Building stakeholder theory with a decision modeling methodology. Business \& Society, 40(2), 133-166.

Woolverton, A., \& Dimitri, C. (2010). Green marketing: Are environmental and social objectives compatible with profit maximization? Renewable Agriculture and Food Systems, 25(02), 90-98.

Wry, T., Lounsbury, M., \& Jennings, P. D. (2013). Hybrid vigor: Securing venture capital by spanning categories in nanotechnology. Academy of Management Journal, amj-2011. 
Yunus, M. (2011). Building social business: The new kind of capitalism that serves humanity's most pressing needs. PublicAffairs.

Zadek, S., \& Thake, S. (1997). Practical people, noble causes. How to support community-based social entrepreneurs. London: New Economics Foundation.

Zedeck, S., \& Mosier, K. L. 1990. Work in the family and employing organization. American Psychologist, 45(2): 240.

Zahra, S. A., Gedajlovic, E., Neubaum, D. O., \& Shulman, J. M. (2009). A typology of social entrepreneurs: Motives, search processes and ethical challenges. Journal of Business Venturing, 24(5), 519-532.

Zhang, Y., Waldman, D., Han, Y., \& Li, X. (forthcoming). Paradoxical leader behavior in people management: Antecedents and consequences. Academy of Management Journal. 
APPENDIX A: Variable operationalization

\begin{tabular}{|c|c|c|c|}
\hline Variables & Variable name & "Variable definition/operationalization & Variable source \\
\hline \multirow[t]{5}{*}{$\begin{array}{l}\text { Dependent } \\
\text { variables }\end{array}$} & $\begin{array}{l}\text { The centrality of competing } \\
\text { logics }\end{array}$ & $\begin{array}{l}\text { Composite of four 7-point Likert-type items assessing the degree to which } \\
\text { top management discuss about social/beneficiaries issues. }\end{array}$ & $\begin{array}{l}\text { Survey from } \\
\text { middle-manager/ }\end{array}$ \\
\hline & & $\begin{array}{l}\text { Composite of four 7-point Likert-type items assessing the degree to which } \\
\text { top management discuss about financial/strategic issues (Muller \& Kolk, } \\
\text { 2009; Weaver et al., 1999). }\end{array}$ & \multirow[t]{4}{*}{$\begin{array}{l}\text { Survey from } \\
\text { middle-manager }\end{array}$} \\
\hline & & $\begin{array}{l}\text { Formula for the centrality of competing logics, adopted by Janis- Fadner } \\
\text { coefficient of imbalance (Deephouse, 1996; Greenhous, Collins, \& Shaw, } \\
\text { 2003; Janis \& Fadner, 1965; Pollock \& Rindova, 2003) }\end{array}$ & \\
\hline & & Coefficient $=\frac{\left(S^{2}-S F\right)}{C^{2}}$ if $S>F ; 0$ if $F=S ; \frac{\left(S F-F^{2}\right)}{C^{2}}$ if $F>S$, & \\
\hline & & $\begin{array}{l}\text { where } \mathrm{S} \text { is the attention to social/beneficiaries issues, } \mathrm{F} \text { is the attention of } \\
\text { financial/strategic issues, and } \mathrm{C} \text { is the total attention. The range of this } \\
\text { variable is }-1 \text { to } 1 \text {, where }-1 \text { equals "attention to all social/beneficiaries } \\
\text { issues" and } 1 \text { equals "attention to all financial/strategic issues." }\end{array}$ & \\
\hline \multirow{3}{*}{$\begin{array}{l}\text { Independent } \\
\text { variables: } \\
\text { Study One }\end{array}$} & Ethical Investors in Investor & Calculated as the ratio of internal and external investments without & Survey from \\
\hline & Stake & $\begin{array}{l}\text { financial expectations to the total investments in the social } \\
\text { enterprises }\end{array}$ & entrepr \\
\hline & $\begin{array}{l}\text { Reciprocity inCustomer } \\
\text { Stakeholder }\end{array}$ & $\begin{array}{l}\text { Calculated by the ratio of customers motivated by reciprocity to the } \\
\text { total customers in the social enterprises }\end{array}$ & $\begin{array}{l}\text { Survey from } \\
\text { Social entrepreneur }\end{array}$ \\
\hline
\end{tabular}


Cross-Sector Workers in

Employee Stakeholder

Independent Founder's non-profit

variables:

Study Two

Moderator

variables:

Study Two

Control

Variables:

Study One and

Two

Prior Performance

Attainment Discrepancy

Firm Age
Calculated by the ratio of employees having experience both social and commercial sectors to the total employees

The number of years the social entrepreneurs reported having worked in the non-profit sector prior to starting the current social enterprise

Composite of two 7-point Likert-type items assessing the degree to which CEOs evaluate the current trend (Plambeck \& Weber, 2010; Thompson, Zanna, \& Griffin, 1995; see Appendix B).

$\mathrm{A}=(\mathrm{D}+\mathrm{C}) / 2-(\mathrm{D}-\mathrm{C})$

, where $\mathrm{D}$ is the dominant reaction and $\mathrm{C}$ is the conflicting reaction

Measured by entrepreneur's (1) years of work experience in for-profit organization(s), (2) years of work experience in non-profit organization(s), (3) Numbers of industries, (4) Numbers of organizations, (5) Numbers of functions, (6) Age, (7) Career experience (years), (8) Education level

The sum of top management's attention both to social issues and commercial issues (Muller \& Kolk, 2009; Weaver et al., 1999; see Appendix B)

Measured by eight items, a 7-point Likert scale (Stam \& Elfring, 2000; Wang \& Bansal, 2012)

Dichotomous variable of " 1 " for positive score of (current performance expectation - past performance), and " 0 " otherwise

Measured by subtracting the date of founding from 2014 (Julian \& Oforidankwa, 2013)
Survey from

Social entrepreneur

Survey from

Social entrepreneur

Survey from

Social entrepreneur

Survey from

Social entrepreneur

Archival/

Survey from

Social entrepreneur

Survey from middle-manager

Archival/

Survey from

Social entrepreneur 
Ratio of Debt

Industry

Type

Diversity of Board of

Directors

$\overline{\mathrm{s}}$

Control

Variables:

Study Two

\section{Founder Gender}

Founder Education Level

Founder's for-profit experience
Measured by Firm's long-term debt divided by total assets (Barnett \& Salomon, 2012)

Seven dummy variables to control for eight industrial categories: (1) Arts and Culture, (2) Civil and Human Rights, (3) Economic Development, (4) Education, (5) Environment, (6) Health/Healthcare, (7) Public Service, and (8) others

Four dummy variables to control for five types of activities: (1) Social Service, (2) Work Integration Social Enterprises (WISEs), (3) Mixture of social service and WISEs, (4) Community-based, (5) Others.

The formula is $1-\sum_{i=1}^{n} P_{i}^{2}$, where $\mathrm{P}$ is the proportion of board of directors with a past experience category $\mathrm{i}, \mathrm{N}$ is the total number of experience categories. In this study, I identified four categories of past experience: (1) social sector, (2) commercial sector, (3) both social and commercial sectors, and (4) non-experience.

Dichotomous variable of " 1 " if CEO is the chairperson of the board, and "0" otherwise

Measured by the logarithm of the age

Archival/

Survey from

Social entrepreneur

Dummy coded " 1 " if founder is male, and " 0 " if not

Measured by $1=$ high school, $2=$ bachelor's degree, $3=$ master's degree, and $4=$ doctoral degree.

The number of years the social entrepreneurs reported having worked in the for-profit sector prior to starting the current social enterprise 
APPENDIX B: Vignette for Ambivalent Interpretation

\section{[Ambivalent evaluation of Strategic Issues-Case]}

Korean government decided to change the policy on social entrepreneurship from direct support to indirect guidance. For example, Korean government has provided financial support to all accredited social enterprises for first three years. However, the government now will try to enhance market-oriented methods such as linking sales channels, increasing government purchasing, and developing capital market for social entrepreneurship.

To what extent do you agree with the following statements?

Positive interpretation $(1=$ strongly disagree, $7=$ strongly agree $)$

Our company will benefit from the current trend described above.

The current trend described above comprises a potential gain for our company.

Negative interpretation $(1=$ strongly disagree, $7=$ strongly agree $)$

The current trend described above is something negative for our company.

There is a high probability of losing a great deal because of the current trend described above 
APPENDIX C: Characteristics of Interviewed Social Enterprises

\begin{tabular}{|c|c|}
\hline Case & Principal Activities \\
\hline 1 & $\begin{array}{l}\text { A social venture (not accredited by Korean government) providing the new } \\
\text { and more sustainable ad-system for internet-based companies }\end{array}$ \\
\hline 2 & An accredited social enterprise, a catering services hiring disabled people \\
\hline 3 & $\begin{array}{l}\text { An accredited social enterprise, a cleansing service firm employing socially } \\
\text { disadvantageous people }\end{array}$ \\
\hline 4 & $\begin{array}{l}\text { A social venture start-up, preparing the full launching the online/mobile } \\
\text { gaming company. It provides the games to donate to charity }\end{array}$ \\
\hline 5 & An accredited social enterprise, making a mobile app for donating to charity. \\
\hline 6 & $\begin{array}{l}\text { An accredited social enterprise, developing and providing healing and } \\
\text { recovery programs for community. }\end{array}$ \\
\hline 7 & $\begin{array}{l}\text { A social venture (not accredited by Korean government, but supported by } \\
\text { capital city) offering web-based service for social dining networks }\end{array}$ \\
\hline 8 & $\begin{array}{l}\text { An accredited social enterprise, a fair tourism company, which connects } \\
\text { travelers with local communities as well as provides more sustainable ways of } \\
\text { tourism }\end{array}$ \\
\hline 9 & $\begin{array}{l}\text { A social venture (not accredited by Korean government) serving a plat-form } \\
\text { business with companies for fair tourism }\end{array}$ \\
\hline 10 & An accredited social enterprise, a social work services in nursing homes \\
\hline 11 & $\begin{array}{l}\text { An accredited social enterprise, Maintenance, Repair, and Operating (MRO) } \\
\text { Supply service. It recruits and supports social enterprises as potential suppliers } \\
\text { of MRO to big commercial companies. }\end{array}$ \\
\hline
\end{tabular}




\section{CURRICULUM VITA}

NAME: Tae Jun Bae

ADDRESS: Weller Hall 120, Zarb Business School

Hempstead, NY 11549

DOB: $\quad$ Suncheon, South Korea, Dec 19, 1977

EDUCATION: $\quad$ Ph.D. in Entrepreneurship (August 2010 - August 2015)

College of Business

University of Louisville, Louisville, Kentucky

Expected Graduation: August, 2014

M.S. in Strategic Management (March 2004 - February 2006)

School of Business

Hanyang University, Seoul, Korea

Graduation: February, 2006

B.S. in Business Administration (March 1996 - February 2004)

School of Business

Hanyang University, Seoul, Korea

Graduation: February, 2004

EMPLOYEE HISTORY： Instructor, Management and Entrepreneurship

Zarb Business School, Hofstra

University (Full-time, tenured track) (Sep, 2014 - present) 